\section{WASHINGTON UNIVERS!TY}

Department of Chemistry

Dissertation Committee:

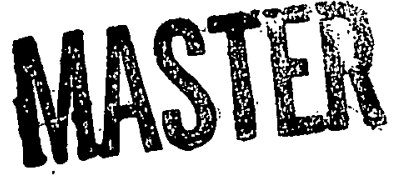

CFSTI PRCES

Herbert A. Potratz, Chairman

Arthur C. Wahl

Kent C. Condie

OF MODERN AND FOSSIL MARINE MOLLUSCAN SHELLS

by

н c: $\$ 3.00 ;$

Mary Mei-Ling Huang Cheng

A dissertation presented to the Graduate School of Arts and Sciences

of Washington University in partial fulfillment of the requirements for the degree of Doctor of Philosophy

B. Assumes any liablities with respect to the use of, or for damages resulting from the of any information, apparatus, method, or process disclosed in this report.

As As used in the extent that ployee or contractor of the Comnshe - such employee or contractor of the Commission, or employee to his employment or contract disseminates, or provides access to, any information pursuan
with the Commission, or his employment with such contractor. with the

June, 1966

Saint Louis, Missouri
} 


\section{DISCLAIMER}

This report was prepared as an account of work sponsored by an agency of the United States Government. Neither the United States Government nor any agency Thereof, nor any of their employees, makes any warranty, express or implied, or assumes any legal liability or responsibility for the accuracy, completeness, or usefulness of any information, apparatus, product, or process disclosed, or represents that its use would not infringe privately owned rights. Reference herein to any specific commercial product, process, or service by trade name, trademark, manufacturer, or otherwise does not necessarily constitute or imply its endorsement, recommendation, or favoring by the United States Government or any agency thereof. The views and opinions of authors expressed herein do not necessarily state or reflect those of the United States Government or any agency thereof. 


\section{DISCLAIMER}

Portions of this document may be illegible in electronic image products. Images are produced from the best available original document. 


\section{TABLE OF CONTENTS}

Chapter.

List of Tabies

iv

List of Figures

v

Acknowledgements

vi

I. Introduction

11. Theory of Uranium Decay Series Methods for Dating Marine Molluscan: Shelis.

1. General Growth and Decay Equation.

2. $T h^{230} / \mathrm{U}^{234}$. Me thod

3. $u^{234} \%$ un 238 Method.

1.1.1. ... I sotop.ic Ther i um and Uranium Compositions of Modern and Fossi.l Marine Molluscan. Shell.s

IV. Criteria. to be Applied... in. Evaluating.: Resul.t.s

V. . Discussion of Resul.ts...

1. State of Preservation. (Mineralogy)

2..... Urani um Content

3. Thoritum-232 Content. . 29

4. Th228/Th232 Activity Ratio 31

5. $U^{234} /$ A $^{238}$ Activity Ratio 34

6. Consistency of $\mathrm{Th}^{230} / \mathrm{U}^{234}$ Ages with Stratigraphic Data

7. Closed System Versus Open System Conditions

VI. Summary 
Chapter

1. Preparation of Samples

II. Procedures 49

1. Isotopic Thorịm and Uranium Analysis 49

A. Separation of Uranium and Thorium 51

B. Purification and Electrodeposition of

Thorium $\quad 52$

C. Purification and Electrodeposition of

Uranium 53

D. Counting and Alpha Spectrometry of Thorium and Uranium I sotopes. : $\quad 54$

E. Calculation of Isotopic Thorium and Uranium Compositions.... . . . $\quad 57$

F. Notes 64

2. Total Uranium Analysis 69

A. Fluorimetric Method $\quad 69$

B. Alpha Pulse Height Analysis Method 73

111. Determination of Calcium Carbonates Mineralogy by $X$-Ray Diffraction $\quad 75$

IV. Description of Samples. $\quad \therefore 79$

Bibliography. ' 84 


\section{LIST OF TABLES}

Table. Number

Page

1. Uranium, Actino-uranium and Thorium Decay Series .. . 2

2 .. Data for A $230 / A_{2} 238$ vs. Time for Various Values of $R$

3. Data for $A_{T h} 230 / A_{1} 34$ vs. Time for Various Values of $R, \quad 14$

4. Data for $A_{U_{i}} 234 / A_{U} 238$ vs. Time for Various Values of $R$

5. Isotopic Thorium and Uranium Compositions of the Modern and the Fossil Marine Molluscan Shells 19

6. The Uranium Content of Modern and Fossil Marine Mollusks 25

7. Thorium Content of Modern and Fossil Shelis 30

8. Comparison of Thorium and Uranium Activities in Mollusks and Typical Pacific Coral Samples 32

9. $T^{228} / \mathrm{Th}^{232}$ Activity Ratios in Modern and Fossil Shells 33

10. U234/U238 Activity Ratios in Modern and Fossil Specimens 37

11. $\mathrm{Th}^{230} / \mathrm{U}^{234}$ Ratios and Estimated Geological Ages of Fossil

She 11.5

12. Closed System Versus Open System Conditions in Fossil Marine Carbonates

13. Summary

14. The Nuclear Characteristics of Certain Thorium Isotopes and Daughters of Th228

15. The Nuclear Characteristics of Some Uranium Isotopes

16. Comparison of Uranium Results

17. Mineralogy of the Molluscan Shell Samples

18. Uranium, Thorium and Radium Content of Mississippian Limestone Standard \#1 


\section{LIST OF FIGURES}

Figure Number

1. Theoretical Decay and Growth Curves for $\mathrm{U}^{234}$ and $\mathrm{Th}^{230}$

in a Fossi Marine Mollusk $(R=1 \% 15)$

2. Histogram of Uranilim Concentrations, in Modern and Fosshl.

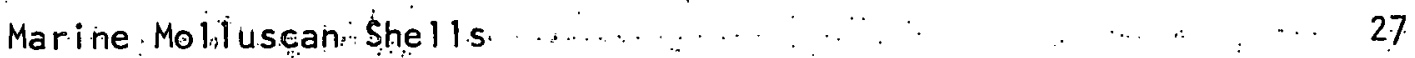

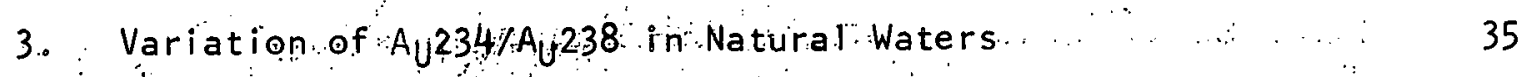

4. Adsorption of the Elements from HCl on Strongly Basic Anion

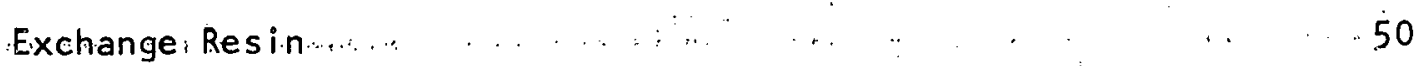

5. Adsorption of the Elements from $\mathrm{HNO}_{3}$ on-Strongly Basic Anion. Exchange. Resin _. . . . . . $\quad \ldots$

6. Block Diagram of the Circuit Used for Alpha Spectrometry ․ 56

7. The Alpha-Spectrum of Thorium I sotopes I solated from: Sample US.SR-F.-3

8. The Alpha-Spectrum of Uranium Isotopes: I solated from Sample Cal. $-\mathrm{F}-4$ :

9. Electrodeposition Cell. 68

10. The X-Ray Spectrum of $90 \%$ Aragonite, Pure STROMBUS GIAS, Mixed with $10 \%$ Pure Calcite.

11. Calcite: Aragonite Calibration Curve 
The, author wishes to express her gratitude to Professor H. A.' Potratz for his advice and guidance; to Washington University for Shell and Universal 'Match Fellowships awarded during the course of her graduate' study; to the United States Atomic Energy Commission for financial support under contract number AT(11-1):-581; to $W$. C. Bradley of the University of Colorado, to D. M. Hopkins, D. S. McCulluch, and T. Karlstrom of the U. S.' Geological Survey who supplied the samples which formed the basis for this work; to Professor.H. D. Levin of Washington University for identification of the shell samples from Russia.

The author also wishes to express her appreciation to Professor K. C. Condie and Professor A. C. Wahl for their comments on and criticisms of the manuscript. 


\section{INTRODUCTION'}

The slow decay of naturally occurring radioactive elements in the earth's crust has ticked off the seconds with unalterable precision since the earth was born. Thus by measuring the amount of the elements' decay. we can determine the age of the material of which they are a part. More than a dozen long-lived natural radioisotopes have been discovered. However, we are interested only in the uranium, actino-uranium and thorium series in this study. Table 1 shows the members and the transformation of these three series.

In undisturbed samples of very old materials the members of the se three radioactive series will be in secularequilibrium. However, the loss or gain, by natural processes, of the parent or daughter elements in the material causes disequilibria within the decay series. Normally such natural processes are slow and consequently disruption of equilibrium in the radioactive families will be noticeable only if the separation or enrichment processes involve nuclides. with relatively long half-lives.

The disequilibria that one may expect to observe in the three naturally occuring radioactive families usually arise because of gain or loss of one or more of the following nuclides (half-lives given in parentheses):

'Thị 'dissertation was prepared under the direction of Professor Herbert A. Potratz. 
Table 1

- Uranlum, Actino-uranium and Thorium Decay Series
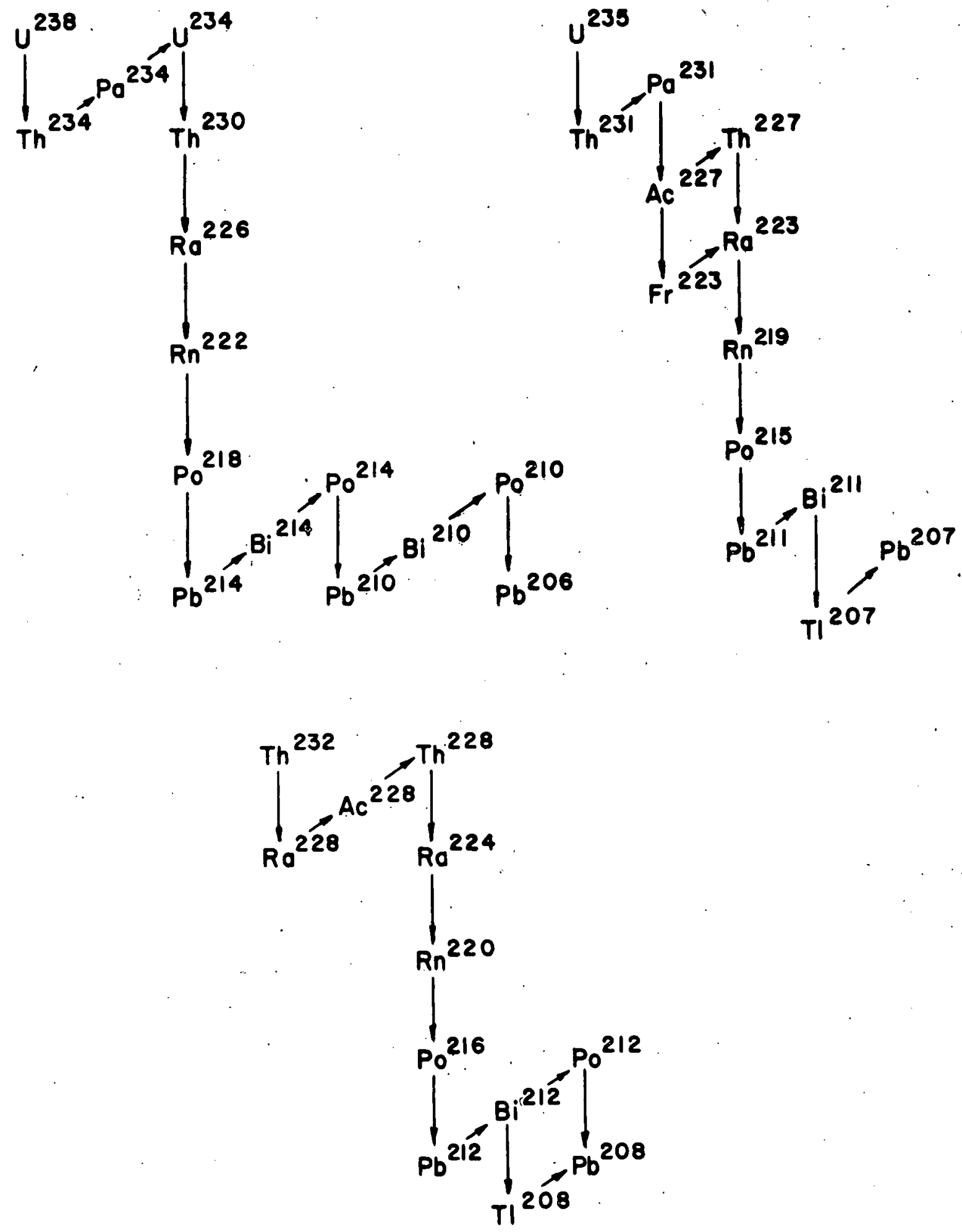
1. Uranium series

$$
\begin{aligned}
& U^{238}\left(4.5 \times 10^{9} y_{\cdot}\right), U^{234}\left(2.48 \times 10^{5} y_{.}\right), \operatorname{Th}^{230}\left(75,200 y_{\circ}\right) . \\
& \operatorname{Ra}^{226}\left(i ; 620 y_{\circ}\right), \operatorname{Pb}^{210}\left(22 y_{.}\right), P o^{210}(138 \text { days }) .
\end{aligned}
$$

2. Act ino-uranium series

$$
u^{235}\left(7.1 \times 10^{8} y_{.}\right), P a^{231}\left(3.4 \times 10^{4} y_{\cdot}\right), A^{227}(22 \text { y.) }
$$

3. Thorium series

$$
\operatorname{Th}^{232}\left(1.4 \times 10^{10} y_{0}\right), \operatorname{Ra}^{228}\left(6.7 y_{0}\right), \operatorname{Th}^{228}\left(1.9 y_{0}\right)
$$

The other short-lived daughter: elements are expected to be in equil: ibrium with thei.r long-lived parents.

When uranium is incorporated into a marine carbonate wi thout its following products, the increase of the daughter elements can be used for age determination. if there is no gain or loss of uranium and the daughter elements. The first attempt to date carbonates by this me thod was made on marine corals by Barnes, Lang and Potratz, who found that coral limestone cuttings taken over the first two hundred feet in drillingson Elugelab island in the Eniwetock Atoll exhibited an irregular increase of ionium to uranium with increasing depth which presumably was a direct consequence of the $\mathrm{Th}^{230}$ to $\mathrm{U}^{238}$ disequilibrium in the ocean water. ${ }^{2}$

This discovery gave rise to the possibility of determining absolute age for marine carbonates in the range from approximately 5,000 years $B$. $P$. to 300,000 years B.P...,...partially filling the gap between the $\mathrm{C}^{14}$ and the $\mathrm{U}-\mathrm{Pb}, \mathrm{K}-\mathrm{Ar}$, and Rb-Sr methods of dating; $\mathrm{Ft}$ In-1958 Sackett published $\mathrm{Th}^{230} / \mathrm{U}^{2 \cdot 38}$ ratios for coral limestone cuttings from Parry Island, Eniwetok (1956).

2J. W. Barnes, E. J. Lang and H. A. Potratz, Science, 124: 175

$* B$. P. is the abbreviated form of Before Present. 
Atoll and for other calcium carbonate materials. 3

Three basic conditions must be fulfilled for the Th230-U238 dating method to be valid.. (1) The original marine-deposited calcium carbonate must contain a measurable amount of uranium; (2) it must be initially. free of $T^{230}$ or contain this nuclide at a low and predictable concentration; and (3) the specimen must, during aging, behave as a closed system:

Blanchard made an intensive study on thirty modern marine mollusks from: fourteen geographic locations and on corals and ancient shells from a number of well defined marine horizons. He also set up several criteria. by which one could select samples which would probably yield:-reliable $\mathrm{Th}^{230} / \mathrm{U}^{238}$ àges $\mathrm{s}$. Where these criteria were fulfilled, the ages corresponded rather well with age estimates based on stratigraphic considerations" or $\mathrm{C}^{14}$ analyses. 4

From the work of Sacket and Blanchard, the following conclusions were made:

(1) Marine calcium carbonates were found to contain uranium in a measurable quantity. The amount present was usually in the range 0.1 to 5.ppm. This satisfies the first condition for dating calcium carbonates by the $\mathrm{Th}^{230}-\mathrm{U}^{238}$ method. Both Blanchard and Broecker reported that living marine mollusks have less uranium then their fossil counterparts, 4,5 Two possible explanations were given for this difference: Either the oceans (1963).

${ }^{3} W_{n}$. M. Sackett, PhD Thesis, Washington University. St.: Louis, Mo: (1958)

${ }^{4}$ : $L$ : Blanchard, PhD Thesis, Washington University, St . Louis, Mo.

${ }^{5}$ W. S. Broẹker, J. Geophys, Res. 68, 2817 (1963). 
contained more uranium during the years these fossil shells were developing; or all of the fossil. shells were contaminated with uranium after the organism's death and deposition.

(2) The initial Th ${ }^{230}$ concentration was very nearly zero. This satisfies the second condition specified above.

(3) Whether or not a marine carbonate fulfills the third condition, the closed system condition, was uncertain.

Blanchard has shown that ages based. on $\mathrm{Th}^{230} / \mathrm{U}^{238}$ in a number of well preserved fossil marine mollusk specimens are in agreement wi th age estimates of those specimens based on stratigraphic considerations. However, the agreement between the $T^{230 / 4} 238$ and the stratigraphlic age can not be taken as good evidence that the age obtained is correct. Additional evidence must be sought to support the assumption that closed system conditions have prevailed in the specimen since the time of its deposition.

The first purpose of the work reported in this thesis was to seek additional criteri.a which may be applied to fossil marine mollusks as. test.s. of: closed system conditions.... The second purpose was to apply the se criteria to two series of:well1 preserved fossill marine mollusks.

A series of stratigraphically: equivalent samples from marine terraces on the California coast was chosen for part of this investigation. .. It is assumed that these-specimens were deposited at a time in the past when the sea stood approximately 100 feet above its present level.6. A second series of samples came from Russia. They were collected from deposits associated with Anzhu 11 transgression, the Karginian transgression,.. the Kazantsevian transgression and the Sanchugovian transgression with estimated

6W. C. Bradley, Bull. Geol. Soc. Amer., 67, 675 (1956) 
$-6-$

geologic ages of $22-45,000$ years $B$. . P., 22-45,000 years $B, P_{,}, 70-$ 100,000 years $B_{0} P_{0}$, and $110-180,000$ years $B_{\text {. }} P$. respectively. 7

7 Personal communication from V. A. Zubakov to Thor Karlstrom, U. S. Geological Survey. 
1. THEORY OF URANIUM DECAY SERIES METHODS FOR

DATING MARINE MOLLUSCAN SHELLS

1. GENERAL GROWTH AND DECAY. EQUATION

$\because \ln$ a radioactive series $N_{1} \stackrel{\lambda_{1}}{\longrightarrow} N_{2} \stackrel{\lambda_{2}}{\longrightarrow} N_{3} \stackrel{\lambda_{3}}{\longrightarrow} N_{4} \ldots$

$\frac{d N_{1}}{d t}=-\lambda_{1} N_{1} \quad$ and $\quad N_{i}=N_{1}^{0} e^{-\lambda_{1} t}$

where $\ddot{N}_{1}$ is the number of unchanged a toms of $N_{1}$ at time $t, N_{1}^{0}$ is the inumber present at $t=0$ and $\lambda_{1}$ is a decay constant characteristic of the species $N_{1}$. The second species is formed at the rate at which the first decays. $\lambda_{1} N_{1}$, and it.se If decays at the rate $\lambda_{2} N_{2}$. Thus,

$$
\frac{\mathrm{dN}}{\mathrm{dt}}=\lambda_{1} \mathrm{~N}_{1}-\lambda_{2} \mathrm{~N}_{2}
$$

This linear differential equation is solved with the condition $N_{2}=N_{2}^{O}$ at $t=0$, and we obtain the solution for $\mathrm{N}_{2}$.

$$
N_{2}=\frac{\lambda_{1}}{\lambda_{2}-\lambda_{1}} N_{1}^{0}\left(e^{-\lambda_{1} t} \cdot-e^{-\lambda_{2} t}\right)+N_{2}^{0} e^{-\lambda_{2} t}
$$

$N_{3}$ may be found by solving the new differential equation:

$$
\frac{d N_{3}}{d t}=\lambda_{2} N_{2}-\lambda_{3} N_{3}
$$

The solution for $N_{n}$ with $n \geqslant 3$ are more complicated. Bateman ${ }^{8}$ has given solution for a series of $n$ members. with the special assumption that at $t=0$ the parent substance alone is present, that is, $N_{2}^{O}=N_{3}^{O}=\ldots=N_{n}^{O}=0$.

This solution is,

$$
\begin{aligned}
& N_{n}=c_{1} e^{-\lambda_{1} t+\ldots \cdot c_{n} e^{-\lambda_{n} t}} \\
& c_{1}=\frac{\lambda_{1} \lambda_{2} \cdot \cdot \cdot \lambda_{n-1}}{\left(\lambda_{2}-\lambda_{1}\right)\left(\lambda_{3}-\lambda_{1}\right) \ldots\left(\lambda_{n}-\lambda_{1}\right)} N_{1}^{0}
\end{aligned}
$$

${ }^{8}$ H. Bateman, Proc. Cambridge Phil. Soc, 15, 423 (1910) 


$$
c_{2}=\frac{\lambda_{1} \lambda_{2} \cdot \cdot \cdot \cdot \lambda_{n-1}^{-8-}}{\left(\lambda_{1}-\lambda_{2}\right)\left(\lambda_{3}-\lambda_{2}\right) \cdots\left(\lambda_{n}-\lambda_{2}\right)} N_{1}^{0} \text {, etc. }
$$

If we do require a solution to the more general case with $N_{2}, N_{3} \ldots$. . $N_{n}^{O} \neq 0$, we may construct it as follows. Add to the Bateman solution for $N_{n}$ in an n-membered series, a Bateman solution for $N_{n}$ in an $(n-1)$

- membered series with substance 2 as. the parent, and, therefore, $\mathrm{N}_{2}=\mathrm{N}_{2}$ at $t=0$. Next add a Bateman solution for $N_{n}$ in an $(n-2)$-membered series, and so on.

\section{2. $T h^{230} / \mathrm{U}^{234}$ METHOD*}

This method as has already been pointed out is based on the assumptions that, the initial Th230 activity' is equal to zero, that $U^{238}$ and U234 at time zero are in secular equilibrium, and that the sample acts as a closed system with respéct to thorium and uranium. From these assumptions it follows that

$$
N_{T h} 230=N_{U} 238 \frac{\lambda_{U^{238}}}{\lambda_{T h}{ }_{T h}^{230}-\lambda_{U^{238}}}\left(e^{-\lambda_{U^{238}} t} \cdot-e^{-\lambda_{T h}{ }^{230} t}\right)
$$

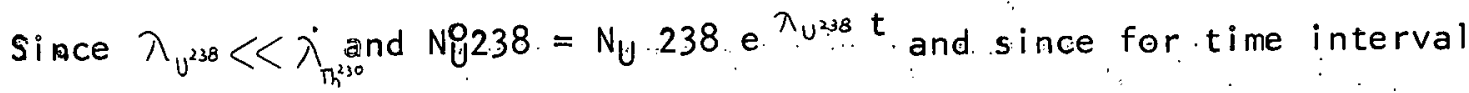
under consideration $t<<1 / \lambda_{u^{238}}$ the equation may be approximated as follows:

$$
N_{T h} 230=N_{U} 238 \frac{\lambda_{U^{238}}}{\lambda_{T h^{230}}}\left(\cdot 1-e^{-\lambda_{T h^{230}} t}\right)
$$

which gives the formula.

$$
t=-\frac{1}{\lambda_{T h^{230}}} \ln \left(1-\frac{A_{T h 230}}{A_{U^{238}}}\right)
$$

However, Cherdyntsev and his co-workers 9 discovered radioactive disequilibrium in nature between $U^{234}$ and its parent $U^{238}$. Thurber 10 confirmed this anomaly and showed. that dissolved uranium in. sea water is enriched in $U^{234}$ activity by 15 percent over that of its parent $U^{238}$. These

* The method is also frequently called the $\mathrm{Th}^{230}$ growth or the Th230/U238' me thod.

9 V. V. Cherdyntsev. P. I. Chalov and G. Z. Khaidarox, Izu. Akad.Nauk SSSR. Moscow, P. 175 (1955)

10 D.L. Thurber, J. Geophys. Res. 67, 4518 (1962). 
discoveries not only required a revision of previous age estimates but also opened the possibility of an independent method based on the decay of the excess $U^{234}$.

Bearing in mind that the $\mathrm{Th}^{230}$ activity arises from the growth toward equilibrium with $U^{238}$ and its equilibrium amount of $U^{234}$ and the growth toward transient equilibrium with the excess $U^{234}$ we write

$$
\begin{aligned}
& A_{T h} 230=\left[\left(\begin{array}{lll}
1-e^{-\lambda} h^{230} & t
\end{array}\right) \cdot A_{U} 238\right] . \\
& +\left[(R-1) A_{U} 238 \frac{\lambda_{T h^{230}}}{\lambda_{T h^{230}}-\lambda_{U^{234}}}\left(e^{-\lambda_{U^{2} 34 t}}-e^{-\lambda_{T h^{230} t}}\right)\right]
\end{aligned}
$$

and $\frac{A_{T h} 230}{A_{U^{238}}}=\left[1-\mathrm{e}^{-\lambda_{T h^{230}} t}\right]+\left[(R-1) \frac{\lambda_{T h^{230}}}{\lambda_{T h^{230}}-\lambda_{U^{234}}}\left(\mathrm{e}^{-\lambda_{\mathrm{U}^{234}} t}-\mathrm{e}^{-\lambda_{T h^{230}} \mathrm{t}}\right)\right]$ where $R$ is the initial activity ratio of $U^{234}$ to $U^{238}$. Substituting the values $2.79 \times 10^{-6}$ year $^{-1}$ and $9.21 \times 10^{-6}$ year ${ }^{-1}$ for the decay constants iof $U^{234}$ and $T^{230}$ respectively, the equation becomes;

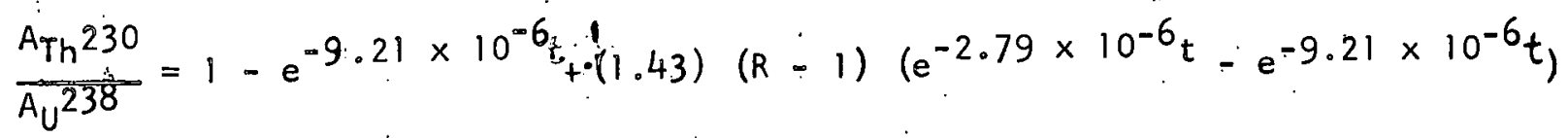

Table 2 lists data for $A_{T h} 230 / A_{j} 238$ versus time for various values of $R$ whère initial $A_{T h} 230$ is zero.

Since $T h^{230}$ is the immediate decay product of $U^{234}$, the age may be expressed in terms of $A_{T h} 230 / A_{U} 234$. To calculate the $T h^{230 / U^{234}}$ age on the basis of $A 9234 / A_{U} 238 \neq 1.00$, the following relationship may be used.

$$
\begin{aligned}
\frac{A_{T h} 230}{A_{U 234}} & =\frac{A_{U} 238}{A_{U} 234} \cdot\left(1-e^{-\lambda_{T h^{230} t}}\right) \\
& +\frac{A_{U} 238}{A_{U} 234}(R-1) \frac{\lambda_{T h}^{230}}{\lambda_{T h^{230}}-\lambda_{U^{234}}} \cdot\left(e^{-\lambda_{U^{234}} t}-e^{-\lambda_{T h^{230} t}}\right)
\end{aligned}
$$

Since $\frac{A_{U^{2}} 238}{A_{U} 234}=\frac{1}{1+(R-1) e^{-\lambda_{U^{234}}}} \quad$ (see $U^{234 / U^{238} \text { method described }}$ later),

the equation becomes

$$
\frac{A_{T h^{230}}}{A_{U^{234}}}=\frac{1-e^{-\lambda_{T h^{230}} t}}{1+(R-1) e^{-\lambda_{U^{234}} t}}+\frac{R-1}{1+(R-1) e^{-\lambda_{U^{234}}}} \cdot \frac{\lambda_{T h^{230}}}{\lambda_{T h^{230}}-\lambda_{U^{234}}}\left(e^{-\lambda_{U^{234}} t}-e^{-\lambda_{T h^{230}} t}\right)
$$


Table 3 lists data for $A_{T h} 230 / A_{U} 234$ vs. time for various values of $R$ where initial $A_{\text {Th }} 230$ is zero.

In applying this equation we use as $R$ the ratio $A_{U} 234 / A_{U} 238$ in present day sea water and living marine organisms. Analyses by Thurber, Goldberg, Blanchard, Osmond and others give values of $R$ in the range 1.07 to $1.27 .18-16$

Osmond et al.applied this method to date corals from the Pleistocene-Key Largo limestone (a fossil coral reef) and Pleistocene Miami oolites. 17

The $T^{230 / 4234}$ method of dating corals: and 00 i tes has been evaluated in detail: for reliability and various criteria have been established by Thurber et $a 1.18$ The method was found to give apparently reliable results to about 200,000 years B.P. ${ }^{19}$.

Fanale and Schaeffer made a comparison of He/U ages with the

11. L. Thurber, ibid.

12 W. S. Broecker and D. L. Thurber, Science, 149, 58 (1965)

13 M. Koide and E. D. Goldberg. Progress in Oceanography, Vol. 3, p. $173 \cdot(1965)$

14 R. L. Blanchard, J.Geophys, Res, 20, 4055 (1965)

$15 \mathrm{~J}$. K. Osmond, J.R. Carpenter, and H. L. Windom, J. Geophys. Res., 20, 1843 (1965)

16 M: H. Cheng, this thesis, $\mathrm{p}$.

$17 \mathrm{~J}$. K. Osmond, J.R. Carpenter, and H. L. Windsom, op. cit.

18 D. L. Thurber, W. S. Broecker; R. L. Blanchard and H. A. Potratz, Science 149, 55 (1965)

19W. S. Broecker and D. L. Thurber, Science 149, 58 (1965) 
$\mathrm{Th}^{230} / \mathrm{U}^{234}$ ages for selected Pleistocene and Tertiary shells and corals and found that the ages are in good agreement except for those fossils. for which independent criteria indicate a chemically open system. 20

Thurber extended the study of this method to marine terraces and. - Pleis tocene beach formations and concluded that $\mathrm{Th}^{230} / \mathrm{U}^{234}$ ages for mollusks are more difficult to evaluate than those obtained for coral and 001 ite. 21 Stearns and Thurber have determined apparent $T^{230} / \mathrm{U}^{234}$ ages of fossil mollusks from the Mediterranean and Moroccan littorals. 22 They believe these apparent ages show sufficient internal consistency and agreement with other estimates of age to justify further exploration of their usefulness.

3. $U^{234} / U^{238}$ METHOD

This method is based on the decay of the $15 \%$ excess $U^{234}$ activity to secular equilibrium with its parent $U^{238}$. To calculate the $U^{234} / U^{238}$ age on the basis of $A_{U}^{0} 234 / A_{U}^{\circ} 238=1.15$, an equation can be obtained as follows:

$$
\begin{aligned}
& \text { follows: } \\
& \qquad N_{U^{234}}=N_{U^{238}}^{0} \frac{\lambda_{U^{238}}}{\lambda_{U^{234}}-\lambda_{U^{38}}}\left(e^{-\lambda_{U^{238}} t}-e^{-\lambda_{U^{234}} t}\right)+N_{U^{234}}^{0} e^{-\lambda_{U^{234}} t} . \\
& \text { since } \lambda_{U^{238}}<<\lambda_{U 234} \text { and } N_{U 238}^{0}=N_{U 238} e^{\lambda_{U^{238}} t} .
\end{aligned}
$$

the equation may be approximated for $t<1 / \lambda_{U^{238}}$ as follows:

$$
\frac{A_{u^{234}}}{A_{u^{238}}}=1-e^{-\lambda_{U^{234}} t}+R e^{-\lambda_{u^{234}} t} \risingdotseq i+(R-1) e^{-\lambda_{U^{234}} t}
$$

20F. P. Fanale and 0: A.o. Schaeffer, Science 149, 312 (1965)

$21_{D}$. L. Thurber, Symposium on Marine Geochemistry, Narragansett Marine Laboratory, University of Rhode Island, Occasional Publication No. 3, 1 (1965)

${ }^{22}$ C. E. Stearns and D. L. Thurber, Quaternaria, VII, Roma, 29 (1965). 


$$
\frac{A_{U} 234}{A_{U 238}}=1+0.15 \mathrm{e}^{-2.79 \times 10^{-6} t}
$$

Table 4 lists data for $A_{U} 234 / A_{U} 238$ as a function of time for various values: of $R$.

The $U^{234} / \mathrm{U}^{238}$ method is based on the following assumptions:

(1) $\quad A_{U}^{O} 234 / A_{U}^{O} 238=1.15$

(2) The sample has remained a: chemically closed system.

Application of the $U^{234} / \mathrm{U}^{238}$ method to the dating of deep sea

sediments has been investigated by. $K_{u}{ }_{0} 23 .: 1 \mathrm{t}$ has been concluded that the sediments do not form a.closed system and that post-depositional migration of $\mathrm{U}^{234}$ in the sedimentiary column takes place.

The possible usefulness of the $U^{234} / U^{238}$ method for dating other materials remains to be demonstrated.

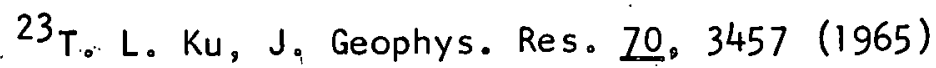


Table 2

Data for $A_{T h}{ }^{230 / A_{U}} 238$ vs. Time for Various Values of $R$

\begin{tabular}{|c|c|c|c|}
\hline $\begin{array}{c}t \\
\left(y^{\prime} s_{0}\right)\end{array}$ & & $A_{\operatorname{Th}^{2}} 230 / A_{\mathrm{v}^{2}} 238$ & $\because$ \\
\hline & $(\mathrm{R}=1.15)$ & $(\mathrm{R}=1.20)$ & $(R=1.30)$ \\
\hline 0 & 0.00 & 0.00 & 0.00 \\
\hline 10,000 & 0.10 & 0.11 & 0.11 \\
\hline 20,000 & 0.19 & 0.20 & 0.22 \\
\hline 40,000 & 0.35 & 0.37 & 0.40 \\
\hline 60,000 & 0.48 & 0.50 & 0.54 \\
\hline 80,000 & 0.59 & 0.61 & 0.66 \\
\hline 100,000 & 0.68 & 0.70 & 0.76 \\
\hline 120,000 & 0.75 & 0.78 & 0.83 \\
\hline 140,000 & 0.81 & 0.84 & 0.90 \\
\hline 160,000 & .0 .86 & 0.89 & 0.95 \\
\hline 180,000 & 0.90 & 0.93 & 0.99 \\
\hline 200,000 & 0.93 & 0.96 & 1.0 .2 \\
\hline 250,000 & 0.99 & $\ldots \mathbb{1} .01$ & $1.07 \ldots$ \\
\hline $300,000 \ldots$ & -1.02 & $\cdots 1.04$ & $\therefore 1.10$ \\
\hline 350,000 & 1.03 & 1.06 & 1.10 \\
\hline 400,000 & 1.04 & 1.06 & 1.10 \\
\hline 450,000 & 1.04 & 1.06 & 1.10 \\
\hline 500,000 & 1.04 & 1.06 & 1.10 \\
\hline
\end{tabular}


Table 3

Data for $A_{T h} 230 / A_{\mathrm{g}} 234$ vs. Time for Various Values of $R$

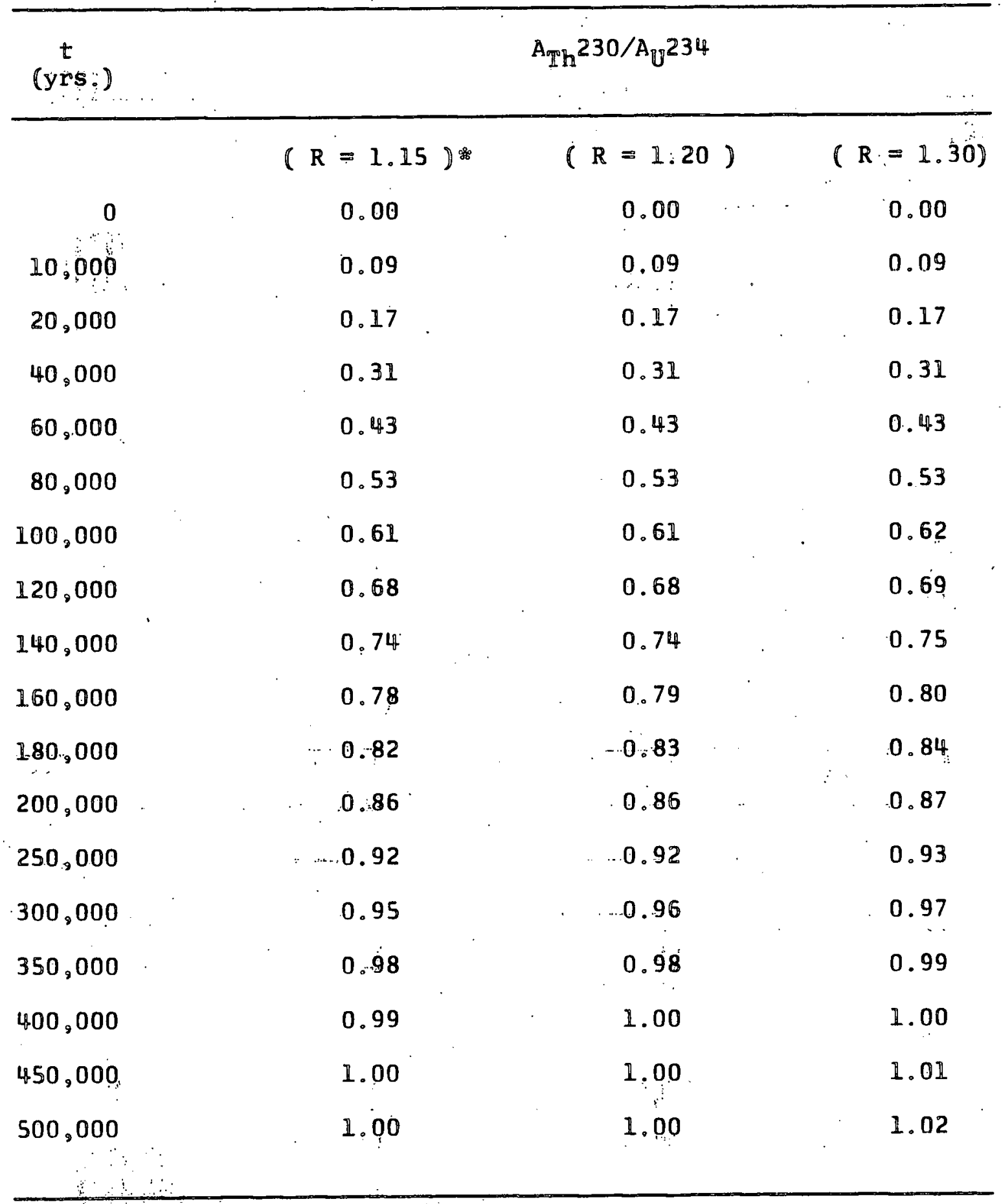

The graphical representation of these data for $R=1.15$ is given in Figure 1 . 
Table \&f

Data for $\AA_{\mathbb{Z}} 234 / A_{0} 238$ vs. Time for Various Values of $R$

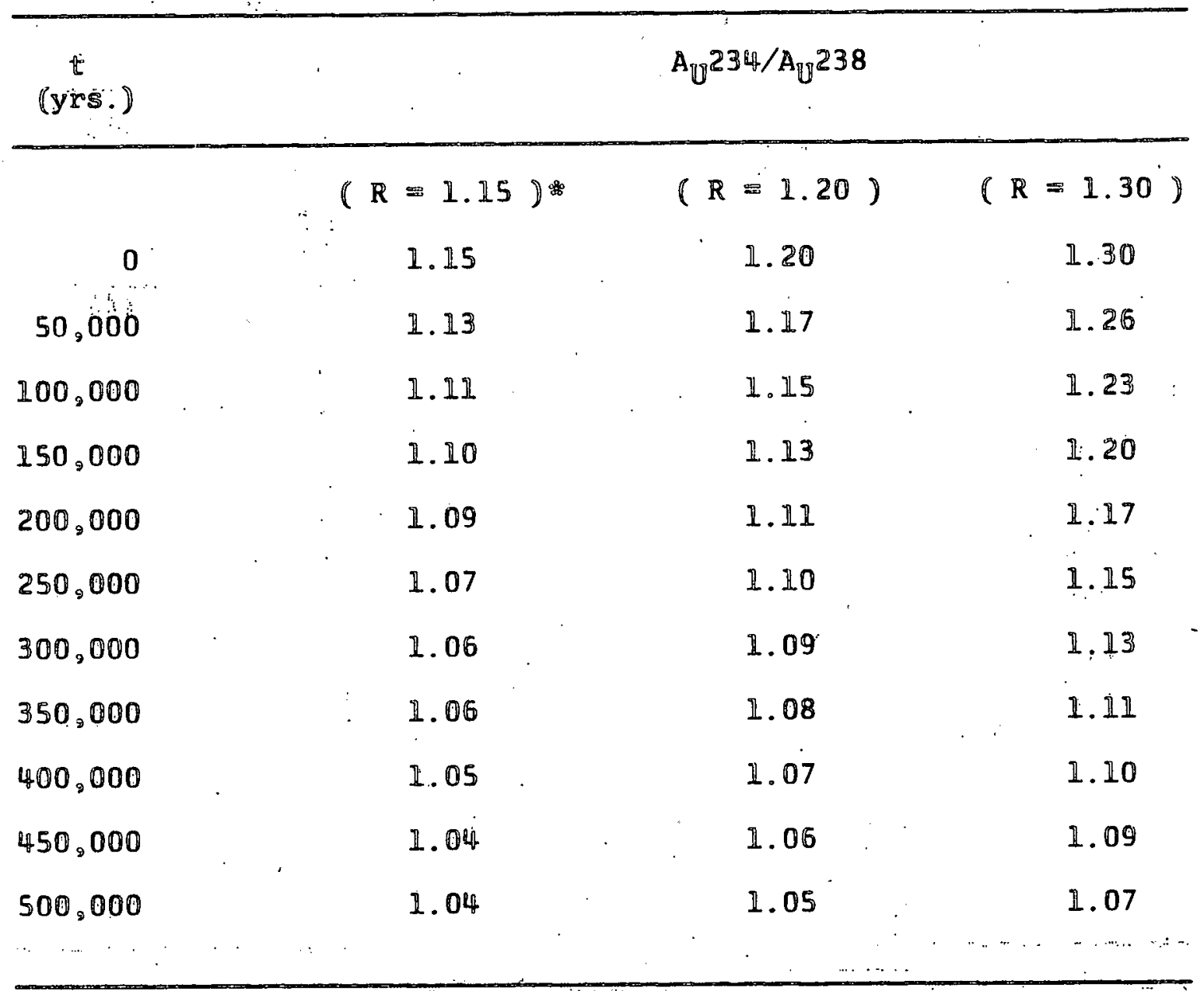

whe graphical representation of these data for $R=1.15$ is given in Figure 1 . 


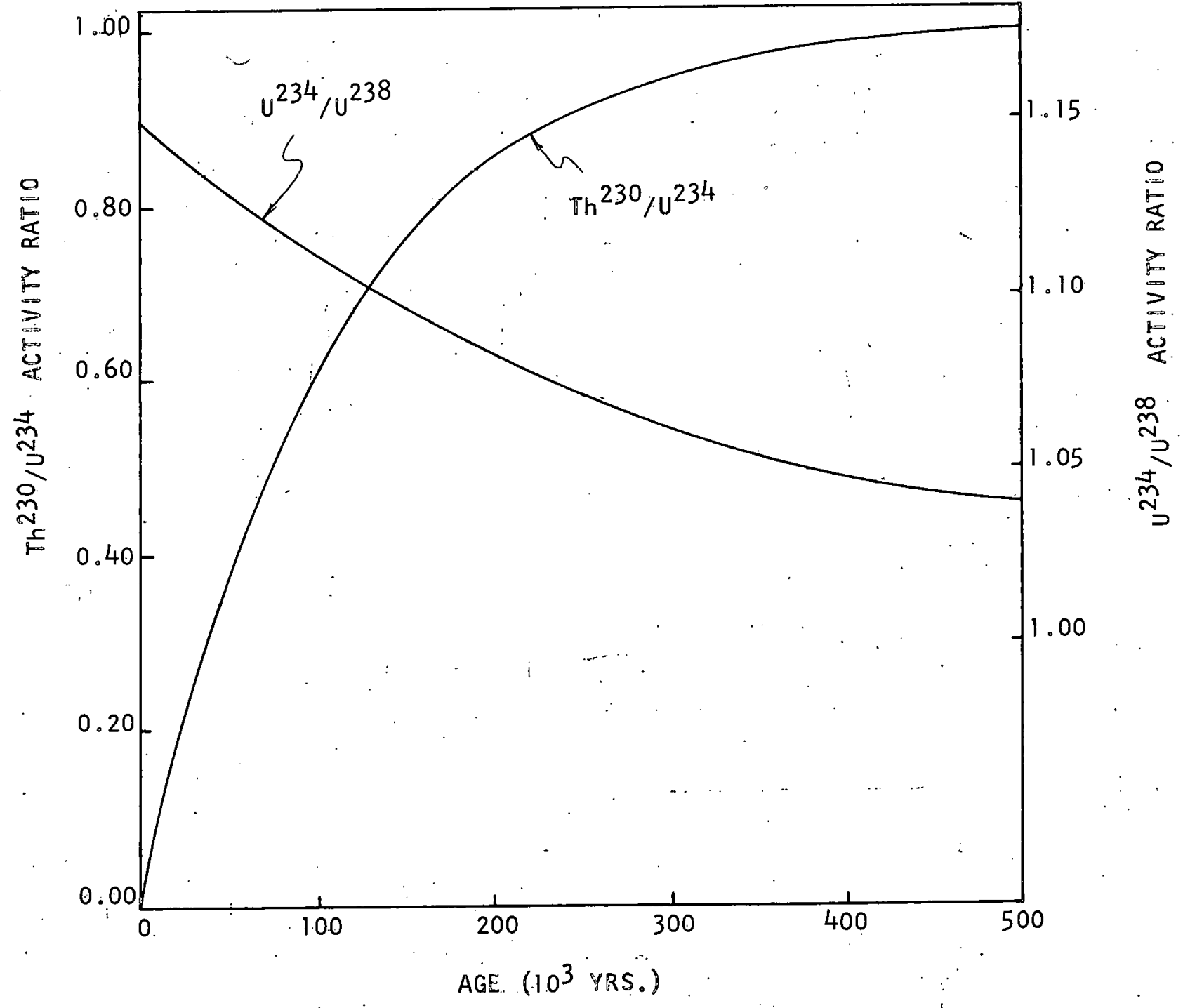

Figure 1. Theoretical Decay and Growth Curves for $\mathrm{U}^{234}$ and $\mathrm{Th}^{230}$ in a Fossil Marine Mol Tusk (R: $=\cdots, 15)$. 


$$
-17-
$$

111. ISOTOPIC THORIUM AND URANIUM COMPOSITIONS OF MODERN AND FOSSIL MARINE MOLLUSCAN SHELLS

\section{INTRODUCTION}

The samples analyzed fall. into the following categories:

(1) A. 1 imestone standard designated as MLS \# 1.

(2) A fossil marine shell sample which shows clear evidence of open "system conditions. This" is designated as Alas.-F-D-1.116.

(3) A series of well preserved marine shells from the first marine terrace on the California coast near Santa Cruz. These samples are designated Cal .-M-1, Cal $C$ - F-1, etc., where "'M" indicates: "modern" and "F." indicates "fossill.....The"fossil shells in this series are stratigraphically equivalent.

...(4) A... series of well preserved fossil-marine shells from Russia designated USSR-F-1, USSR-F-2, etc. The stratigraphic age estimates on these shells range... from 22,000, to $180,000 .:$ years..B.P.

(5). A sample from Greenland collected near the source of sample, 61Ahp453 and 61-Ahp-456, which Blanchard had analyzed and had shown to have $\mathrm{Th}^{230} / \mathrm{U}^{234}$ ages. in good agreement. with the estimated age of the geologic unit from which they were collected. 24.

The she11. samples"'were thoroughly cleaned, as described in. Appendix 1, before analyzing. Total uranium and i sotopic thorium and uranium were determined by the methods described in Appendix 11. Mineralogy of the samples were determined the $x$-ray diffraction me thod given in Appendix I:11.. A detailed description of each sample is given in Appendix IV.

24R. L. Blanchard, Thesis, op. cit., p. 93. 
2. I SOTOPIC THORIUM AND URANIUM COMPOSITIONS

In order to check the validity of the analytical procedure, the Mississippian limestone standard was analyzed for isotopic thorium and uranium content. The results are given in Table 18 (P. 83 -)... The se results show good agreement wi th those obtained by other workers in this and other laboratories as can be seen from the table. Blank analyses on reagents were made but no alpha activity was found. The chemical. yiellds for thorium analyses - we re usually in the range of 80 .to 100 percent.: For uranium analyses the yields: we re - in the : range of 50 to 90 percent. " The results of isotopic thorium and uranium .analyses for all the sample are given in Table 5 . 
Table 5

Isotupic Thorium and Uranium Compositions of Modern and fossil Marine Molluscan Shells

\begin{tabular}{|c|c|c|c|c|c|}
\hline $\begin{array}{c}\text { Sample } \\
\text { Designation }\end{array}$ & 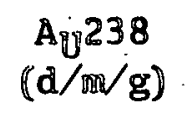 & $\begin{array}{c}A_{\mathbb{U}} 234 \\
(\mathrm{~d} / \mathrm{m} / \mathrm{g})\end{array}$ & $\begin{array}{l}\mathrm{ATh}_{\mathrm{Th}} 232 \\
(\mathrm{~d} / \mathrm{m} / \mathrm{g})\end{array}$ & $\begin{array}{r}A_{T h}^{230} \\
(\mathrm{~d} / \mathrm{m} / \mathrm{g})\end{array}$ & $\begin{array}{l}A_{T h} 228 \\
(d / m / g)\end{array}$ \\
\hline Cal. $-M-1$ & $\begin{array}{r}0.26 \\
( \pm 0.01)\end{array}$ & $\begin{array}{c}0.33 \\
( \pm 0.02)\end{array}$ & $\leqslant 0.002$ & $\leqslant 0.007$ & $\leqslant 0.06$ \\
\hline $\mathrm{Cal} . \mathbb{F}-\mathbb{1}$ & $\begin{array}{c}11.04 \\
( \pm 0.15)\end{array}$ & $\frac{1.31}{(+0.20)}$ & $\begin{array}{c}0.018 \\
( \pm 0.003)\end{array}$ & $\begin{array}{c}0.67 \\
\therefore( \pm 0.04)\end{array}$ & $\begin{array}{c}0.14 \\
( \pm 0.02)\end{array}$ \\
\hline Call $-F-2$ & $\begin{array}{c}0.10 \\
( \pm 0.01)\end{array}$ & $\begin{array}{c}0.11 \\
( \pm 0.01)\end{array}$ & $\begin{array}{c}0.010 \\
(+0.002)\end{array}$ & $\begin{array}{c}0.052 \\
( \pm 0.006)\end{array}$ & $\begin{array}{r}0.025 \\
( \pm 0.004)\end{array}$ \\
\hline Call. $-F-3$ & $\begin{array}{c}1.18 \\
(40: 10)\end{array}$ & $\begin{array}{c}1.49 \\
( \pm 0.13)\end{array}$ & $\begin{array}{c}0.018 \\
( \pm 0.002)\end{array}$ & $\begin{array}{c}0.69 \\
( \pm 0.04)\end{array}$ & $\begin{array}{c}0.093 \\
( \pm 0.007)\end{array}$ \\
\hline Cal $-F-4$ & $\begin{array}{c}0.49 \\
( \pm 0.04)\end{array}$ & $\begin{array}{c}0.56 \\
( \pm 0.06)\end{array}$ & $\begin{array}{c}0.007 \\
( \pm 0.002)\end{array}$ & $\begin{array}{c}0.076 \\
(+0.009)\end{array}$ & $\begin{array}{c}0.033 \\
( \pm 0.007)\end{array}$ \\
\hline$U S S R-F-\mathbb{1}$ & $\begin{array}{c}0.16 \\
( \pm 0.01)\end{array}$ & $\begin{array}{c}0.29 \\
( \pm 0.02)\end{array}$ & $\begin{array}{c}0.063 \\
( \pm 0.004)\end{array}$ & $\begin{array}{c}0.45 \\
(+0.02)\end{array}$ & $\begin{array}{c}0.10 \\
( \pm 0.01)\end{array}$ \\
\hline USSR $-F=2$ & $\begin{array}{c}0.10 \\
( \pm 0.01)\end{array}$ & $\begin{array}{c}0.15 \\
( \pm 0.01)\end{array}$ & $\begin{array}{c}0.033 \\
( \pm 0.004)\end{array}$ & $\begin{array}{r}0.15 \\
(4001)\end{array}$ & $\begin{array}{r}0.05 \\
( \pm 0.01)\end{array}$ \\
\hline USSR-F-3 & $\begin{array}{c}1.01 \\
( \pm 0.09)\end{array}$ & $\begin{array}{c}1.23 \\
( \pm 0.12)\end{array}$ & $\begin{array}{c}0.074 \\
(+0.008)\end{array}$ & $\begin{array}{r}9.31 \\
( \pm 0.03)\end{array}$ & $\begin{array}{c}0.09 \\
(+0.01)\end{array}$ \\
\hline USSR-F-If & $\begin{array}{c}0.23 \\
( \pm 0.01)\end{array}$ & $\begin{array}{l}0.26 \\
( \pm 0,011)\end{array}$ & $\begin{array}{c}0.024 \\
( \pm 0.003)\end{array}$ & $\begin{array}{c}0.20 \\
( \pm 0.02)\end{array}$ & $\begin{array}{c}0.025 \\
( \pm 0.003)\end{array}$ \\
\hline USSR $=\mathbb{F}=5$ & $\begin{array}{c}0.54 \\
( \pm 0.02)\end{array}$ & $\begin{array}{c}0.72 \\
(+0.05)\end{array}$ & $\begin{array}{c}0.059 \\
( \pm 0: 006)\end{array}$ & $\begin{array}{r}0.30 \\
( \pm 0.02)\end{array}$ & $\begin{array}{c}0.11 \\
( \pm 0.01)\end{array}$ \\
\hline USSR $-F-6$ & $\begin{array}{c}0.26 \\
(\$ 0.01)\end{array}$ & $\begin{array}{r}0.37 \\
( \pm 0.03)\end{array}$ & $\begin{array}{c}0.0 .54 \\
( \pm 0.006)\end{array}$ & $\begin{array}{c}0.25 \\
( \pm 0.02)\end{array}$ & $\begin{array}{c}0.057 \\
(0.006)\end{array}$ \\
\hline $\begin{array}{l}\text { Greenild. }-19 \\
-62 A M M 24\end{array}$ & $\begin{array}{r}0.07 \\
( \pm 0.01)\end{array}$ & $\begin{array}{c}0.09 \\
(0.01)\end{array}$ & $\begin{array}{c}0.074 \\
(\$ 0.004)\end{array}$ & $\begin{array}{c}0.077 \\
( \pm 0.005)\end{array}$ & $\begin{array}{r}0.17 \\
( \pm 0.01)\end{array}$ \\
\hline $\begin{array}{c}\text { Alas }-F-F_{-} \\
\text {Dolil6 }\end{array}$ & $\begin{array}{c}1.92 \\
( \pm 0.07)\end{array}$ & $\begin{array}{c}4.90 \\
( \pm 0.26)\end{array}$ & $=$ & - & - \\
\hline Vall \# & $\begin{array}{c}0.73 \\
( \pm 0.03)\end{array}$ & $\begin{array}{c}0.74 \\
(\$ 0.05)\end{array}$ & $\begin{array}{c}0.030 \\
(+0.006)\end{array}$ & $\begin{array}{c}0.76 \\
(+0.05)\end{array}$ & $\begin{array}{r}0.032 \\
( \pm 0.006)\end{array}$ \\
\hline
\end{tabular}


IV. CRITERIA TO BE APPLIED IN EVALUATING RESULTS

For the uranium decay series methods of dating molluscan shells to be valid the specimen; must during aging, behave as a closed system. Such a: specimen would be expected to meet the following criteria $25-27$

1. State of Preservation. The sample should show no evidence of recrystallization:

2. Uranium Content. :The uranium content of the fossil should not differ greatly from that of i.ts modern counterpart.

3. Thorium-232 Content. . The thorium-232 content of the fossil shouild not differ greatly from that of its modern counterpart.

4. $\mathrm{Th}^{228} / \mathrm{Th}^{232}$ Activity Ratio. This ratio should be 1.0 .

5. U $\mathrm{U}^{234} / \mathrm{U}^{238}$ Activity Ratio. This ratio, corrected for decay of the excess $U^{234}$, should fall within the range of $U^{234} / U^{238}$ ratios in modern marine shells.

6. Consistency. Th $\mathrm{Th}^{230} / \mathrm{U}^{234}$ ages should be consistent with stratigraphic data.

25 R. L. Blanchard, Thesis, op. cit.

26D. L. Thurber, W. S. Broecker, R. L. Blanchard, and H. A. Potratz, Science, 149, 55 (1965)

27C. E. Stearns and D. L. Thurber, op. cit. 


\section{DISCUSSION OF RESULTS}

The results obtained in this work will be discussed in their relationship to the criteriated in the foregoing section while failure to mest these criteria can be taken as evidence of open system conditions i.t. can not be argued that a specimen that satisfies all these conditions necessarily represents a closed system.

\section{1.. STATE OF PRESERVATION (MINERALOGY )}

The two most important calcium carbonate polymorphs composing marine molluscan shells are calcite and aragonite. Calcite is rhombohedral and aragonite, the more dense of the two, is orthorhomblc. Under atmospheric conditions, calcite is thermodynamically stable with respect to aragonite. The standard free energy change of the aragonite to calcite transition is -237 calorles per mole. 28 However, certain márine organisms precipitate aragonite which remains unaltered for thousands of years afterwards. Geologice evidence impl.ies that aragonite at low temperature and pressure will remain unaltered for long periods of time when in contact with solutions similar to those: from which the aragonite was precipitated or when dry sealed.29 In addition, the aragonite to calcite transition is a reconstructive phase transformation which helps to explain the persistence of the aragonite structure. It has al soben suggested that the presence of foreign ions, such as $\mathrm{Pb}^{++}$and $\mathrm{Sr}^{++}$, might stabilize aragonite with respect to calcite at earth surface conditions:

In. the attempt to understand the basic factors influencing the

28W. M. Latimer The Oxidation States of the Elements and The ir Potentials in Aqueous Solutions, p.o 320 (1.959)

29p.E. Cloud, Geochím. et Cosmochim. Acta 26, 867-884:(1962) 
precipitation of calcium carbonate by marine organisms, investigators turned to controlled laboratory experimentation. These experiments show that the formation of aragonitic calcium carbonate is favored by high temperature, a low concentration of precipitating ions, $\mathrm{CO}_{3}^{--}$and $\mathrm{Ca}^{++} 30$, high $\mathrm{pH}^{31}$, and particularly by the presence of divalent cations with an ionic radius larger than that of calcium ion.32-35

... The mineralogy of the calcium carbonate deposited by a marine organism is: not genetically fixed. Lowenstam noted compositions varying from 100. percent calcite to 100 percent aragonite in the same species, in going from:latitudes.590.40! N. to. $7^{\circ} 19^{\prime} \cdot \mathrm{N} .35$ An increased temperature results in a loss of $\mathrm{CO}_{2}$, wi.th an attendant rise in $\mathrm{pH}$. and a reduction of bicarbonate ion, carbonic acid and carbonate ion concentrations. The laboratory investigation mentioned above indicated that all three of these

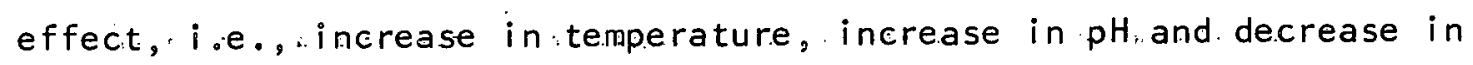
carbonate ion concentration, favor the formation of the aragonite form of calcium carbonate.

When divalent ions larger than calcium ion are incorporated into the crystal lattice the formation of aragonite is favored. Thompson and Chow 36

30 J.L. Wray and F. Daniels, J. Amer. Chem. Soc. 29, 2031-2034 (1957)

31 E.J.-Zeller and J. L. Wray, Bull. Amer. Ass. Petrol. Geol. 40, 140-152. (1956)

32 W. L. Bragg, Atomic Structure of Minerals, p. 1.14 (1.937)

33T. G. Thompson and T. J. Chow, Papers in Marine Biology and Oceanography,..Suppl... to Vol. 3 of Deep Sea Reasearch, 20-39 (1955)

${ }^{34} \mathrm{~F}$. Daniels, Geochim. et Cosmochim. Acta 22, 65-74 (1961)

35 H. A... Lowenstam, Proc. Nat. Acad. Sci.40, 39-48 (1954)

${ }^{36} \mathrm{~T}$. G. Thompson and T. J. Chow, op. cit: 
and Kulp, Túrekian and Boyd 37 have reported that aragonitic calcium. carbonate deposited by marine organisms contains many times more strontium than does organically deposited calcitic calcium carbonate.

The salinity of the ocean water also appears to have an effect in determining the mineralogy of a marine she 11 . Lowenstam 38 , found that low salinities tend to raise the aragonitic fraction synthesized and that fluctuation in composition might be due in part to fluctuations in salinity. The aragonite-calcite ratios of the modern and fossil shells are. determined by $x$-ray diffraction analysis. If the analysis shows calcite to be absent one may conclude that there has been no recrystallization. The presence of calcite, however, cannot be taken as proof that recrystallization has occurred, because some organisms deposit a mixture of calcite and aragonite. The recrystallization process is likely to lead to violation of the closed system assumption.

The results of $x$-ray diffraction analysis are listed in Table 17 (P. 78$)$. In 91 percent of the samples analyzed.,. calcite was below the limit of detection (1-2\% calcite), an observation which we take as evidence that little or no recrystallization has occurred in these samples.

\section{URAN IUM CONTENT}

For the dating: methods based on the uranium-decay series to be useful, the carbonate samples must contain a measurable amount of uranium.

There-are several factors which may influence the uranium content of marine deposited calcium carbonates. One factor is the concentration

37J. L. Kulp, K. Turekian and D. N. Boyd, Bull. Geol. Soc. Amer. 63, 701-706 (1952)

38H. S. Lowenstam, op. cit. 
$-24-$.

of uranium in the ocean waters from which the calcium carbonates have been. deposited. During the time span for which the ionium-uranium ard uraniumuranium ratio might be useful, the uranium concentration in the ocean has probably changed very little. Holland and Kulp have estimated that the uranium concentration has changed less than 20 percent in 107 year. 39 For very old.carbonates, other factors such as the recrystallization of the calcium carbonate are more important in determining their present uranium content. 40

The concentration of calcium in ocean water is $0.4 \mathrm{~g} . / 1.41$

Taking the concentration of uranium in ocean water as $3.0 \times 10^{-6} \mathrm{~g} .11$. , one may calculate the atomic ratio of $\mathrm{U} / \mathrm{Ca}$ to be $1.2 \times 10^{-6} .42$ This is approximately the $U / C a$ ratio one finds in living and fossil aragonitic corals but is much greater than the $U / C$ a ratio in.living: mollusks... This difference may be related to the very porous nature of coral resulting in a large surface area. If the uranium were incorporated after the material was deposited by the exchange of the ionic species in the ocean water and in the solid, the resulting exchange would probably be much more rapid. in.a material such as coral than in a very hard and compact mațerial such as a shell.

39H. D. Hollard and J. L. Kulp, Geochim. èt cosmochim. Acta 5, $197(1954)$

$40 R$. L. Blanchard, Thesis, op. cit.

41 K. Rankama and T. G. Sahama, Geochemistry, p. 287 (1950)

42M. Nakanishi, Bul1. Chem. Soc. Japan 24;36 (1951) 
Table 6

The Uranium Content of Modern and Fossil Marine Mollusks

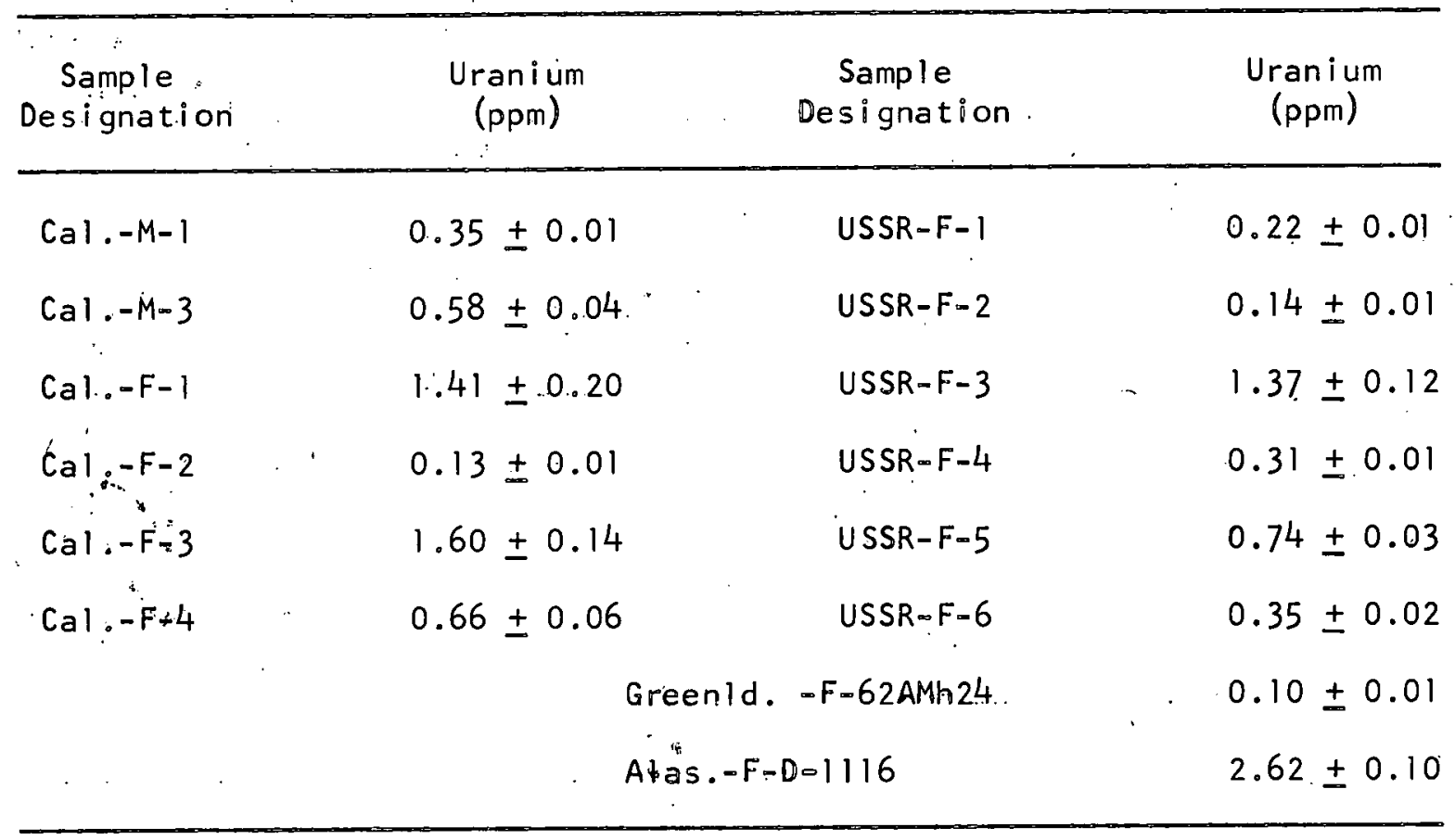

Uranium contents of the shells are listed in Table 6. Fossil mollusks Cal $\mathrm{F}-1$ and $\mathrm{Cal}-\mathrm{F}-3$ contain appreciably more uranium than the ir contemporary counterparts Cal.-M-1 and Cal.-M-3. Both Blanchard 44 and Broecker 43 reported that fossil mollusks have higher uranium concentrations than living mollusks. This relationship. is. clearly demoristrated by the histogram in Figure 2 which is obtained by combining the results of Broecker, 43 Blanchard, 45 Stearns and Thurber, 46 and the data in Table 6 . Two possible explanations are given for this difference. 43,44 Either the ocean contained more uranium during the years these fossil

43 w. S. Brocker, op. cit.

${ }^{44}$ R. L. Blanchard, Thesis, op. cit.

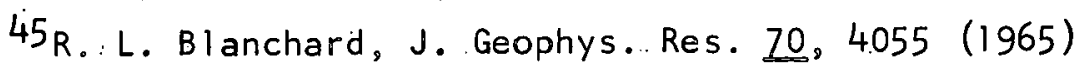

${ }^{46}$ C. E. Stearns and D. L. Thurber, op. cit. 
shells were developing, contrary to the estimates of Holland and Kulp, or the excess üranium was added after death of the organism.

Stearns and Thurber commenting on the results of Broecker and Blanchard have pointed out that $50 \%$ of the living organism shells that were analyzed contained $<0.06 \mathrm{ppm} \mathrm{u}^{238}$, but that fossil shells both within the range of radiocarbon dating and beyond $\left(>25,000\right.$ years $\left.B_{0} P_{0}\right)$ contained significant amounts of $u^{238}(65 \%$ of the fossil shells tested contained between 0.25 and $2.0 \mathrm{ppm} \mathrm{U}^{238}$ ). Moreover, fossils less than 20,000 years old do not, in general contain less $\mathrm{U}^{238}$ than fossils greater than 20,000 years old. They:conclude, therefore, thatu uranium is fixed rapidly by some process such as the degradation of organic material, and that the event dated by $\mathrm{Th}^{230 / 4234}$ ratios is close in time to the death of the organism. 47

Certainly the origin of the uranium in mollusks. must be better understood before the usefullness of these materials for inequilibrium dating can be evaluated.

Another interesting observation from Table 6 is the relatively high uranium concentrations in certain. fossil shells collected from the Cal.ifornia.Coast, (Cal. $-F-i$ and Cal.-F-3), from Russia, (USSR-F-3), and from Alaska,.(Alas.-F-D-1116). Following the arguments of Stearns and Thurber one might assume that, this, excess uranium entered the shell soon after death of the organism. Some evidence to be considered later, however, indicates that this is probably not the case.

Sample Alas.-F-D-1116 has been subjected to extreme and unusual conditions for thousands of years as described on page 41 of this dissertation. During this time physical and chemical changes in the shell material could have occurred... It is not unreasonable to assume that the

47C. E. Stearns and D. L. Thurber, ibid. 


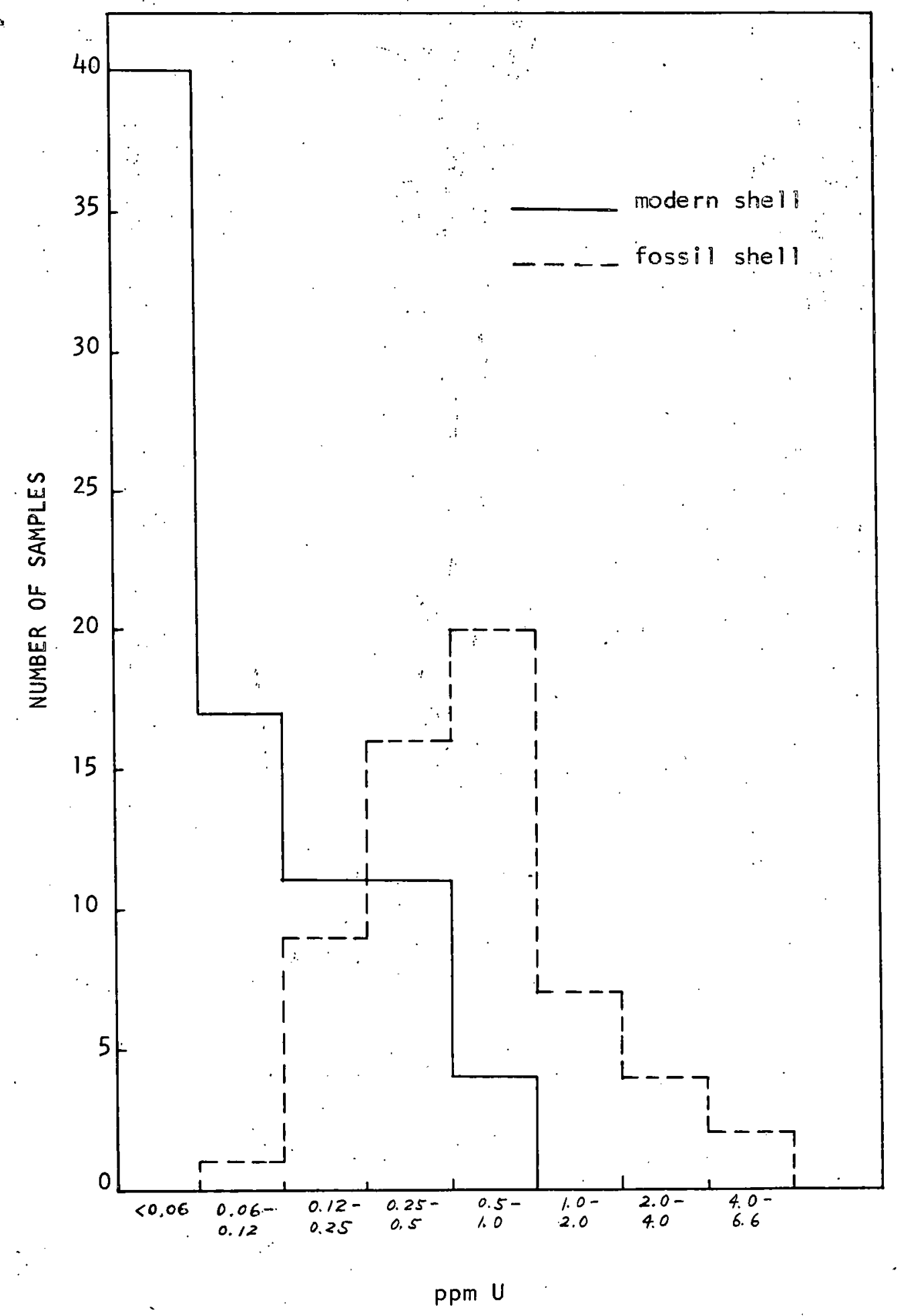

Figure 2. Histogram of Uranium Concentrations in Modern and Fossil Marine Molluscan Shells. 
trace element composition of these shells may have been considerably altered by the prolonged contact with circulating ground waters and possibly also by the recent exposure to direct weathering.

Sample USSR-F-3 contains no detectable calcite; so one may conclude that there has been lift.le or no recrystallization. There was not sufficient sample to permit a check on the possibility of surface contaminàtion by uranium. : Such a check was however made on another fossil sample that was high in uranium content, Cal.-F-3. This was done by dissolving the outer and the inner half of the whole shell separately with $\mathrm{HNO}_{3}$, and determining the concentration of uranium in each fraction by the method given in the appendix. The results obtained were as follows:

BFMC -3 Inside fraction $1.60 \pm 0.13 \mathrm{ppm}$

Outside fraction $1.36 \pm 0.16 \mathrm{ppm}$

The uranium difference between fractions was within the limit of experimental error, indicating: uniform distribution.

Blanchard. has observed that moderî marine shells collected from the California Coast average: somewhat higher. in uranium content than do modern marine shells from other localities. 48 The results here reported, samples Cal.-M-1 and Cal.-M-3, Table 6 and Figure 2 ,. confirm this. Whether this variation in uranium content of the shells is related to the variation. in uranium content of the coastal waters have not been determined.

48 R. L. Blanchard, Thesis, op. cit., p. 29. 


\section{THORIUM-232 CONTENT}

Because of the very low concentration of $\mathrm{Th}^{232}$ in ocean water, appreciable quantities of this isotope would not be expected in marine shells. Blanchard looked for Th232 in 30 modern marine shell specimens collected from 14 locations. In all specimens $T^{232}$ was below hi.s 1 imit of detection which was generally about $0.005 \mathrm{~d} / \mathrm{m} / \mathrm{g} .49$ The data for Cal.-M-1 (Table 7) support.Blanchard's observation. The $\mathrm{Th}^{232}$ content of this shel:1 is less than $0.002 \mathrm{~d} / \mathrm{m} / \mathrm{g}$.

Further examination of the data in Table 7 reveals that the fossil marine mollusks unlike their modern counterparts contain a considerable amount of $\mathrm{Th}^{232}$, an amount such that $A_{T h} 232$. approaches : $A_{T h} 230$ in some specimens. It seems reasonable to assume that this $\mathrm{Th}^{232}$ must have entered the shell after death of the organism. If $\mathrm{Th}^{230}$ entered along with $\mathrm{Th}^{232}$, and it seems likely that this would be the case, then the $T h 230 / \mathrm{U}^{234}$ ratio can not serve as an, age measure.

Tatsumoto and Goldberg have suggested that the concentration of $\mathrm{Th}^{232}$ might provide a means for evaluation of the extraneous $T^{230}$ content of the sample. 50 However, the $\mathrm{Th}^{230} / \mathrm{Th}^{232}$ activity ratio commonly varies between 1 and 4 in surface water (Thurber; unpublished) and between 6 and 30 in sea water. 51,52 Therefore, it is difficult to predict in what proportions these two thorium isotopes would be added to the shell.

This problem of contamination by thorium apparently does not arise or at least appears to be much less serious in corals that have been de-

49 R: L. Bilanchard, Thesis, op cit, , p. 78 .

50 M. Tatsumoto and E. D. Goldberg, Geochim. et Cosmochim. Acta, 1Z, $201^{\prime \prime}(1959)$

51 E: B. Goldberg and M. Kòide, Science, 128, 175 (1958)

52 W. S. Moore and W. M. Sackett, J. Geophys. Res., 69, 5401 (1964) 
Table 7

Thorium Content of Modern and Fossil Shells

\begin{tabular}{|c|c|c|c|c|c|}
\hline $\begin{array}{c}\text { Sample } \\
\text { Designation }\end{array}$ & $\begin{array}{c}A_{T h} 232 \\
(d / m / g)\end{array}$ & & $\begin{array}{l}A_{T h} 230 \\
(\mathrm{~d} / \mathrm{m} / \mathrm{g})\end{array}$ & & $\frac{A_{T h} 230}{A_{T h}^{232}}$ \\
\hline Cal. $-M-1$ & $\leqslant 0.002$ & & $\leqslant 0.007$ & & $\leqslant 9$ \\
\hline Cal.-F-l & $0.018 \pm 0.003$ & & $0.67 \pm 0.04$ & & $37 \pm 7:$ \\
\hline Cal.-F-2 & $0.010 \pm 0.002$ & & $0.052 \pm 0.0 .06$ & & $5 \pm 1$ \\
\hline Cal.-F-3 & $0.018 \pm 0.002$ & & $0.69 \pm 0.04$ & : & $38 \pm 5$ \\
\hline Cal. $-\mathrm{F}-4$ & $0.007 \pm 0.002$ & 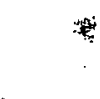 & $0.08 \pm 0.01$ & & $11 \pm 3$ \\
\hline USSR-F-1 & $0.063 \pm 0.004$ & & $0.45 \pm 0.02$ & - & $7 \pm 1$ \\
\hline USSR-F-2 & $.0 .033 \pm 0.004$ & . & $0.15 \pm 0.01$ & & $5 \pm 1$ \\
\hline USSR-F-3 & $0.074+0.008$ & $\therefore$ & $0.31 \pm 0.03$ & & $4 \pm 1$ \\
\hline USSR-F-4 & $0.024 \pm 0.003$ & & $0.20 \pm 0.02$ & & $8 \pm 1$ \\
\hline USSR-F-5 & $0.059 \pm 0.006$ & & $0.30 \pm 0.02$ & & $5 \pm 1$ \\
\hline USSR-F- 6 & $0.054 \pm 0.006$ & & $0.25 \pm 0.02$ & & $5 \pm 1$ \\
\hline $\begin{array}{l}\text { Green1d.-F- } \\
\text { 62AMh24 }\end{array}$ & $0.074 \pm 0.004$ & & $0.077 \pm 0.005$ & & $1 \pm 0.1$ \\
\hline $\begin{array}{l}\text { Alas }-F- \\
D-1116\end{array}$ & $-{ }^{*}=-$ & $\cdot$ & -- & & $139 \pm 57$ \\
\hline MLS \# 1 & $0.030 \pm 0.006$ & , & $0.76 \pm 0.05$ & & $25 \pm 5$ \\
\hline
\end{tabular}


posited and remain in a marine environment as illustrated by the datain Table: 8 .

In this Table modern and fossil mollusk specimens with $\mathrm{Th}^{230} / \mathrm{U}^{234}$ activity ratios over the range 0.00 to 1.00 are paired with modern and fossil coral specimens of similar $\mathrm{Th}^{230} / \mathrm{U}^{234}$ activity ratios. One observes that unlike the mollusks, the fossil corals show no evidence of $\mathrm{Th}^{232}$ uptake. The average $T^{232}$ content in the fossils is no different than in the modern specimen. Also, as indicated by the $\mathrm{Th}^{230} / \mathrm{Th}^{232}$ activity ratios, $\mathrm{A}_{T h} 230$ in the fossil corals is usually several hundred times $A_{T h} 232$.

4. $\mathrm{Th}^{228} / \mathrm{Th}^{232}$

In fossil shells $\mathrm{Th}^{228}$, with a half-life of 1.90 years, should be in radioactive equilibrium with its parent $T^{232}$, i.e.s Th ${ }^{228} / T^{232}$ activity ratio should be equal to one. Any excess $\mathrm{Th}^{228}$ would indicate recent contamination of the shell with thorium and/or Ra228 which is the parent of $\mathrm{Th}^{228}$

$\mathrm{Th}^{228} / \mathrm{Th}^{232}$ activity ratios for the modern and fossil shells are listed in Table 9. The results show that in most of the fossil shells this activity ratio is greater than one. This is good evidence that the system is open or has been open very recently.

Koczy, Picciotto, Poulaert, and Wilgain have observed an excess of $\mathrm{Ra}^{228}$ in coastal waters and have suggested a redissolution of $\mathrm{Ra}^{228}$ from near shore bottom sediments or its introduction from rivers. 53 Thurber 54 has shown that river waters contain unsupported Th ${ }^{22.8}$. Modern shells are known to contain more $\operatorname{Ra}^{226}$ than can be supported by the uranium present 55,56

53F. F. Koczy, E. Picciotto, G. Poulaert and S. Wilgain, Geochim. et Cosmochim. Acta, 11, 103 (1957)

$54 \mathrm{~B}$. L. Thurber, unpublished data

55.R. L. Blanchard, Thesis, op. cit., p. 32

56 W. S. Broecker, op cit. 
Table 8

Comparison of Thorium and Uranium Activities in Mollusks and

Typical Pacific Coral Samples*

\begin{tabular}{|c|c|c|c|c|c|c|c|c|}
\hline Sample & $:$ & $\begin{array}{l}A_{U} 234 \\
(d / m / g)\end{array}$ & $\begin{array}{l}A_{T h} 232 \\
(d / m / g)\end{array}$ & $A_{T h} 230 / A_{U 234}$ & & $A_{T h} 230 / A_{T h} 232$ & . & . \\
\hline $\begin{array}{l}\text { Cal. - M-1 - } \begin{array}{l}\text { Modern } \\
\text { Loc. } 15\end{array} \text { (Modern }\end{array}$ & $\begin{array}{l}\text { mollusk) } \\
\text { Coral })\end{array}$ & $\begin{array}{l}0.33 \\
2.76\end{array}$ & $\begin{array}{r}\leqslant 0.002 \\
0.007\end{array}$ & $\begin{array}{r}\leqslant 0.02 \\
0.004\end{array}$ & $\cdot$ & $\begin{array}{l}\leqslant 9 \\
1.5\end{array}$ & . & $\cdot$ \\
\hline $\begin{array}{ll}\text { Cal }-F-1 & \text { (Fossil } \\
\text { Mu } 7-13 & \text { (Fossil }\end{array}$ & $\begin{array}{l}\text { mollusk) } \\
\text { coral })\end{array}$ & $\begin{array}{l}1.31 \\
2.34\end{array}$ & $\begin{array}{l}0.018 \\
0.002\end{array}$ & $\begin{array}{l}0.51 \\
0.58\end{array}$ & & $\begin{array}{r}37 \\
660\end{array}$ & & \\
\hline $\begin{array}{ll}\text { USSR-F-6 } & \text { (Fossi) } \\
\text { Mu 7-23 } & \text { (Fossi) }\end{array}$ & $\begin{array}{l}\text { mollusk) } \\
\text { Coral })\end{array}$ & $\begin{array}{l}0.37 \\
2.18\end{array}$ & $\begin{array}{l}0.054 \\
0.004\end{array}$ & $\begin{array}{l}0.69 \\
0.68\end{array}$ & & $\begin{array}{r}5 \\
340\end{array}$ & & \\
\hline $\begin{array}{ll}\text { USSR-F-4 } & \text { (Fossil } \\
\text { Mu } 7-34 & \text { (Fossi) }\end{array}$ & $\begin{array}{l}\text { mollusk) } \\
\text { coral ) }\end{array}$ & $\begin{array}{l}0.26 \\
1.96\end{array}$ & $\begin{array}{l}0.024 \\
0.006\end{array}$ & $\begin{array}{l}0.76 \\
0.79\end{array}$ & & $\begin{array}{r}8 \\
300\end{array}$ & & \\
\hline $\begin{array}{ll}\text { Grnld:-F- } & \\
62 A M h 24 & \text { (Fossil } \\
\mathrm{K}-1-16 & \text { (Fossi) }\end{array}$ & $\begin{array}{l}\text { mollusk) } \\
\text { coral })\end{array}$ & $\begin{array}{l}0.09 \\
2.74\end{array}$ & $\begin{array}{l}0.074 \\
0.005\end{array}$ & $\begin{array}{l}0.86 \\
0.87\end{array}$ & & $\begin{array}{r}1 \\
435\end{array}$ & & .. \\
\hline $\begin{array}{l}\text { USSR-F-2 } \\
\text { F-1 }\end{array}$ & $\begin{array}{l}\text { mollusk) } \\
\text { coral }\end{array}$ & $\begin{array}{l}0.15 \\
1.56\end{array}$ & $\begin{array}{r}0.033 \\
0.010\end{array}$ & $\begin{array}{l}1.03 \\
1.00\end{array}$ & & .5 & &. \\
\hline
\end{tabular}

* Data on coral samples are from Thurber, Broecker; Blanchard and Potratz, Science, 149, 56 (1965) 
Table 9

$\mathrm{Th}^{228} / \mathrm{Th}^{232}$. Activity Ratios in. Modern. and. Fossil Shells

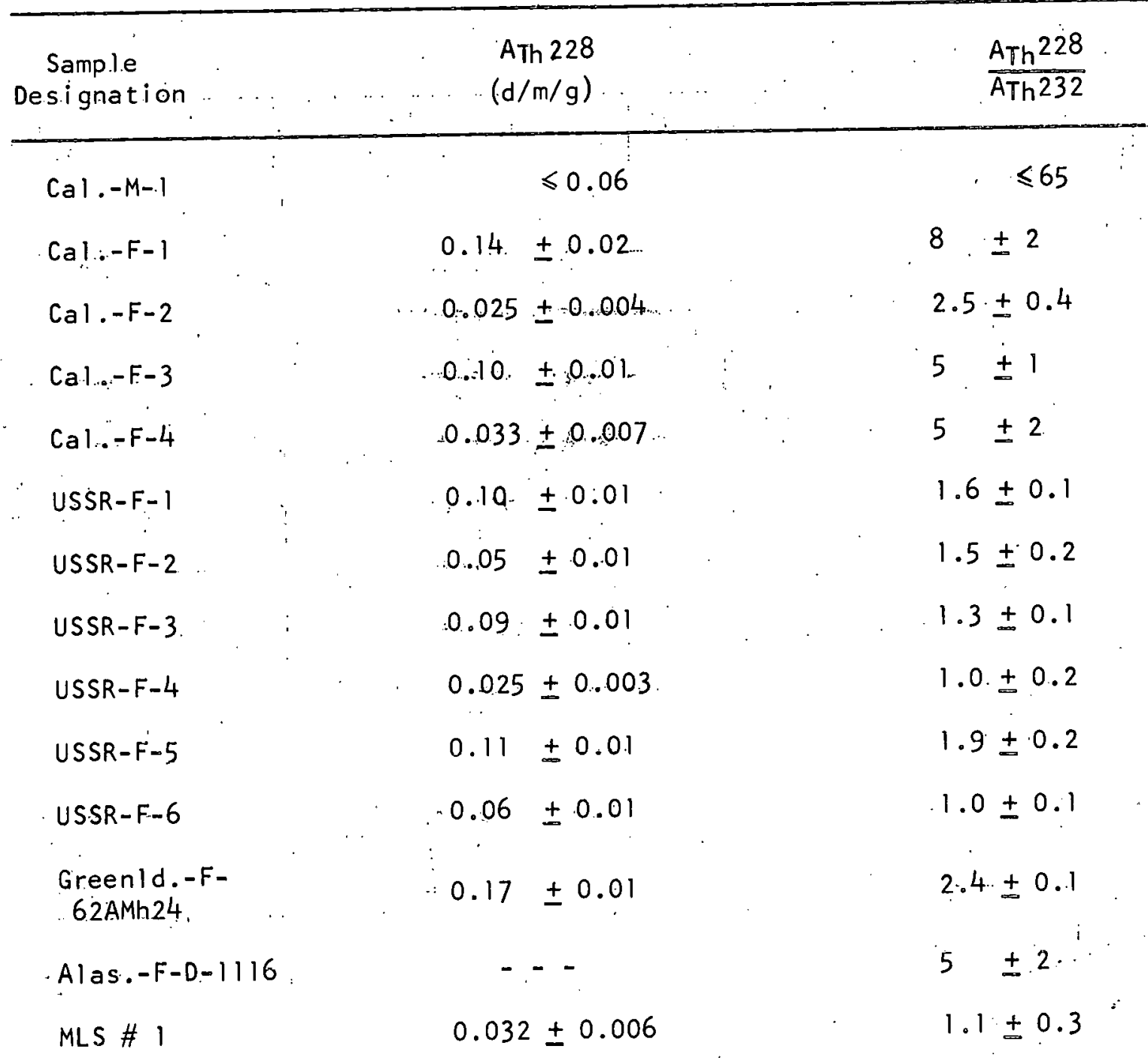


Moore and Sackett have confirmed the presence of excess $R a^{228}$ in coastal waters. 57 Considering the relatively high mobility of radium compared to thorium, these observations lead one to suspect that the excess $\mathrm{Th}^{228}$ in fossil shells may arise from decay of $\mathrm{Ra}^{228}$ which has come into the specimen from ground waters. However we have no data to confirm this.

5. U234/U238 ACTIVITY RATIO

Radioactive disequilibrium between $U^{234}$ and $U^{238}$ in minerals and rocks was initially observed by Cherdyntsev and co-workers. 58,59 The fractionation of these two isotopes is attributed to a hot-atom effect. In minerals the products of $U^{238}$ decay are displaced by recoul into different sites of the crystalline lattice where they reside in the form of foreign, generally-weakly bound, inclustions. During the interaction of weathering solutions with minerals, the radioactive-decay product $U^{234}$ passes into solution to a greater extent than does $U^{238}$. Rosholt et al ${ }^{60}$ showed that U234 preferentially leached at one locality may be subsequently deposited at another, thus giving rise to a deficiency at one location and an excess at another, as compared.with the equilibrium amount:

Figure 3 shows the variation of the $\mathrm{U}^{234} / \mathrm{U}^{238}$ activity ratios in some natural waters - deep ocean water, 61 river: waters ${ }^{62}$ and coastal waters. 63

57W. S. Moore and.W. M. Sackett, J. Geophys. Res., 69, 5401 (1964) 58 V. V. Cherdyntsev, D. P. Orlov, E. A. I sabaev and V. I. Ivanov, Geochemistry USSR. (English Transi.) No:' 10, 927 (1961)

$59 \mathrm{~V}$. V. Cherdyntsex, Abundance of Chemical Elements, p. 107, Univ: of Chicago Press, Chicago (1961) (1963).

$60 \mathrm{~J}$. N. Rosholt, W. R. Shields, and E. L. Garner, Science, 139, 224

$(161 M$. Koide and E. D. Goldberg, Progress in Oceanography, vol. 3 , p. $173 \cdot(1965)$ $\therefore 4$

$62 \mathrm{D}$. L. Thurber, unpublished data.

63.R: L. Blanchard, y Gephys. Res, 70, 4055 (1965) 


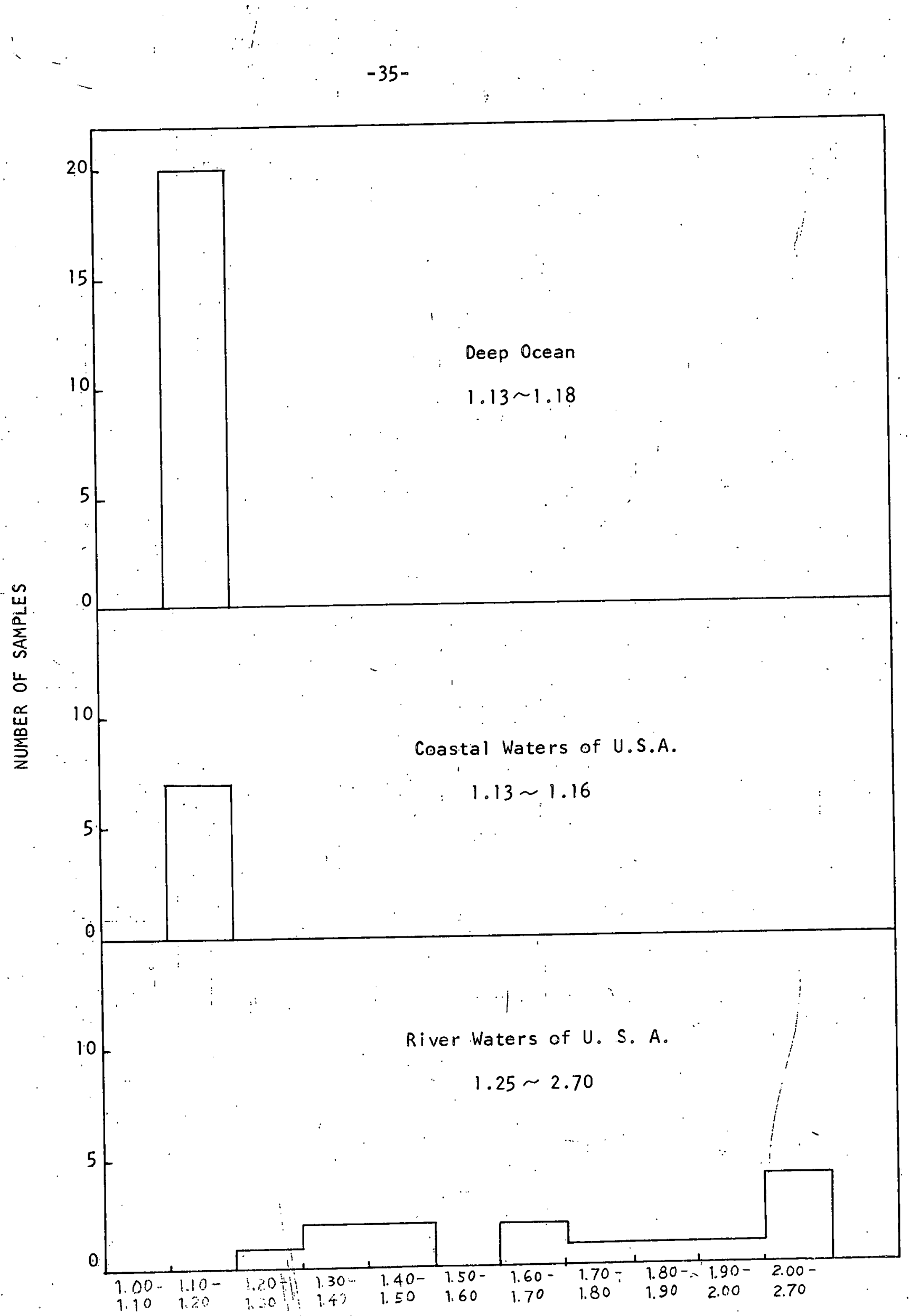

Figure 3. Variation of $A_{U} 234 / A_{U} 238$ in Natural Waters. 
As can be seen from the figure the average ratio for river water is far higher: than "that "of-deep : ocean"water.

If closed system conditions have prevailed, the $U^{234} / U^{238}$ activity ratio in alfossil marine shell, corrected for decay of the excess $\mathrm{u}^{234}$, should not differ from the $U^{234} / \mathrm{U}^{238}$ ratio in a modern marine she 11 . Two assumptions are implicit in this statement. Namely, the $U^{234} / U^{238}$ ratio in all modern marine shells is the same and the $U^{234} / U^{238}$ ratio in living marine shells is the same now as it was in the fossil shells at the time of their formation. The latter assumption seems reasonable but is not subject to direct proof. The assumption that all modern marine shells have identical or nearly identical $\mathrm{U}^{234} / \mathrm{U}^{238}$ activity ratios may be correct. However, tọo few modern specimens have been analyzed to permit a definite conclusion. Coastal surface waters in some locations may have relatively high $U^{234} / \mathrm{U}^{238}$ activity ratios. One would expect this might be the case near a river mouth if the $U^{234} / \mathrm{U}^{238}$ activity ratio in the river water is. high, as it is known to be in some rivers. The $U^{234} / U^{238}$ activity ratio in the coastal water should be reflected in the $U^{234} / U^{238}$ ratio in the marine: organism living in this water.

The $U^{234} / U^{238}$ activity ratios of the marine carbonate samples are l-isted in Table:10.. The ratio for the modern shell, Cal.-M-1, is $1.27^{\prime} \pm$ 0.06 which is somewhat higher than the ratio in ocean water. Whether this relates to a relatively high $U^{234} / U^{238}$ ratio. in the coastal water from which this sample was collected has not been determined. Blanchard 64 has 'analyzed some modern molluscan shells collected at seven locations on the seacoast of the United States and found $U^{234} / \mathrm{U}^{238}$ activity ratios that fall within the range of 1.07 to 1.17. Relatively few modern shells and

${ }^{64}$ R. L. Blanchard, ibid. 
Table 10. $U^{234} / U^{238}$ Activity Ratios in. Modern and Fossil Specimens

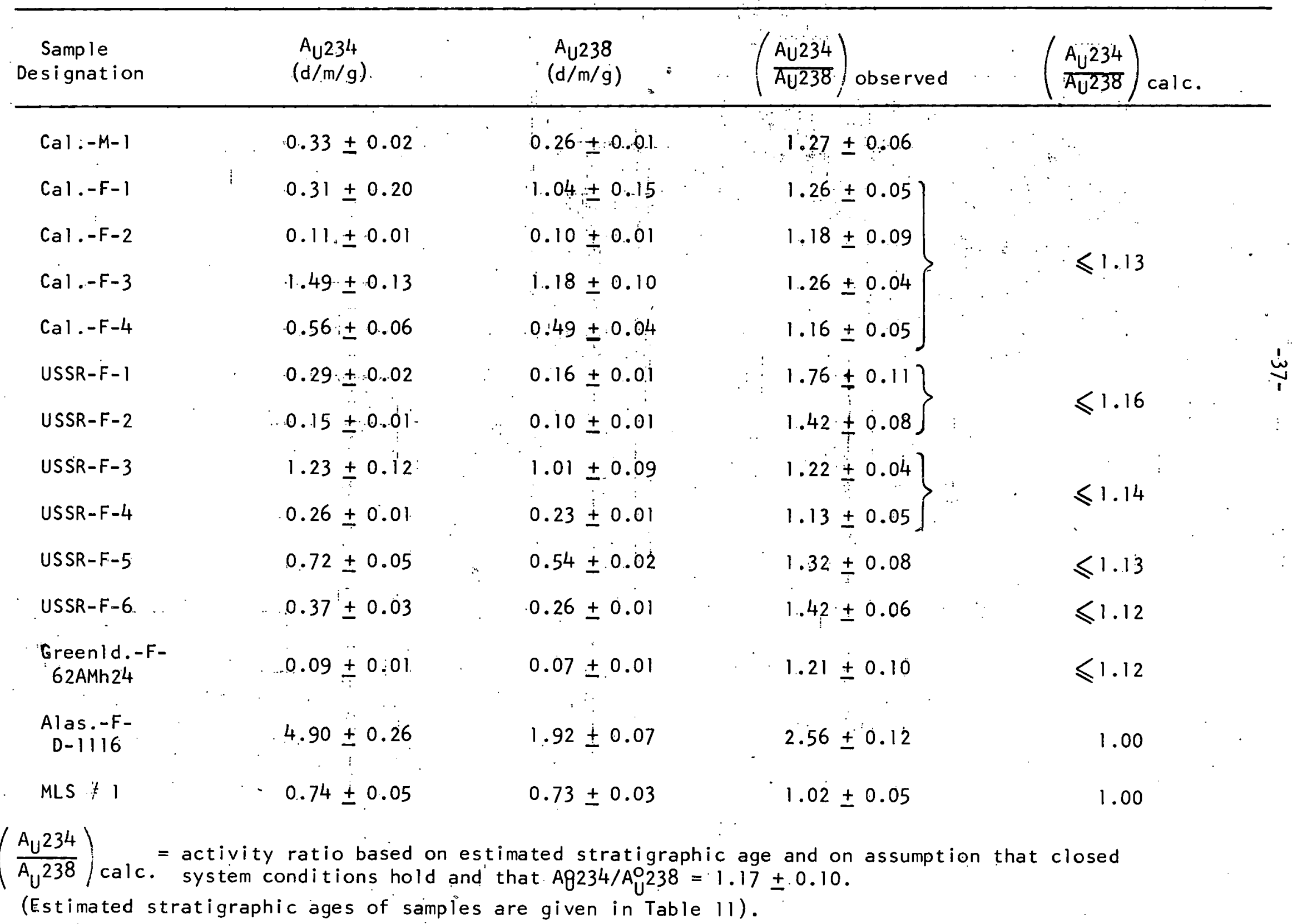


even fewer coastal water-samples have been-analyzed for $U^{234} / U^{238}$, therefore, it-is rather difficult to specify a $U^{234} / U^{238}$ ratio for modern marine shells. From the limited number of results we will tentatively set a ratio of $1.17 \pm 0.10$ for modern marine mollusks.

The $u^{234} / u^{238}$ activity ratio in fossil mollusks then should always be lower.than 1.27 and should approach: 1.00 in the 0.1 dest samples if closed system conditions are met. In Table 10 observed $U^{234} / \mathrm{U}^{238}$ activity ratios are compared with $U^{234} / U^{238}$ activity ratios calculated from the estimated stratigraphic ages of the samples on the assumption that closed system conditions hold and that $A_{U}^{O} 234 / A_{U}^{O} 238=1.17 \pm 0.10$.

In the shells of the Cal. $-F$-series the $U^{234} / U^{238}$ ratios, within limits of experimental error are identiral. The disagreement with the calculated $\mathrm{U}^{234} / \mathrm{U}^{238}$ ratio is not significant because of the uncertainty in the stratigraphic age estimate for these samples (see Table 11).

Most of the samples in the USSR series have $U^{234} / U^{238}$ ratios significantly higher than the calculated ratios. Contamination by ground waters, a subject to be discussed later-, may be the explanation. This al so is assumed to account for the high $U^{234} / U^{238}$ ratio in sample Alas.-F-D-1116 (see page 40).

6. $T^{230} / \mathrm{U}^{234}$ AGES SHOULD BE. CONSISTENT WITH STRATIGRAPHIC DATA

The fossil samples from the California...coast are stratigraphically

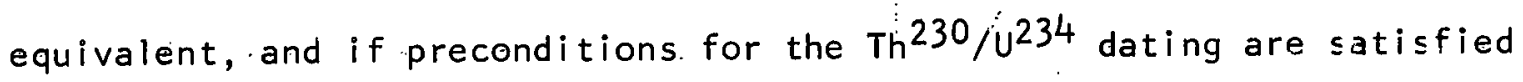
the $\mathrm{Th}^{230} / \mathrm{U}^{234}$ ratios in these specimens should be identical. As can be seen by reference to Table 11, this is not the case. The fact that the stratigraphic age estimate on these shells may be in error is irrelevant.

The samples in the USSR series also lack internal consistency; samples from the same stratum differ widely in observed $\mathrm{Th}^{230} / \mathrm{U}^{234}$ 
Table 11

$\mathrm{Th}^{230} / \mathrm{U}^{234}$ Ratios and Estimated Geological Ages of Fossil Shells

\begin{tabular}{|c|c|c|c|}
\hline $\begin{array}{c}\text { Sample } \\
\text { Designation }\end{array}$ & $\left(\frac{A_{T H} 230}{A U^{234}}\right)_{\text {Obs }}$ & $\begin{array}{l}\text { Estimated } \\
\text { Stratigraphic } \\
\text { Ages } \times 10-3 \text { yrs. }\end{array}$ & $\left(\frac{A_{T h} 230}{A_{U} 234}\right)_{\text {calc. }}$. \\
\hline
\end{tabular}

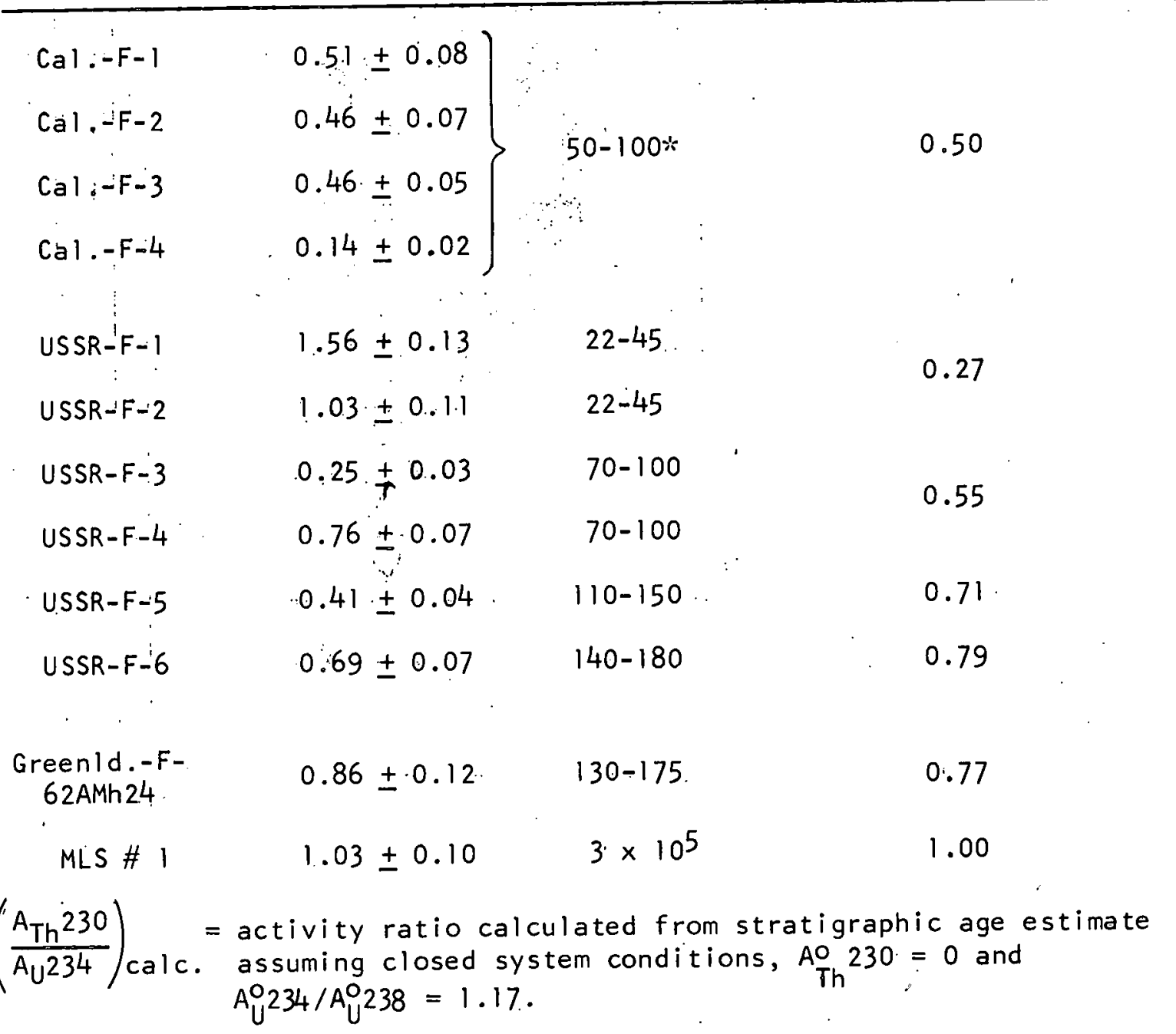

* The samples in the Cal.-F series are stratigraphically equivalent. 
activity ratios. These ratios, moreover, are completely out of line with stratigraphic age estimates. Note, for example, that the shells from the most recent stratum have the highest $\mathrm{Th}^{230} / \mathrm{U}^{234}$ activity ratios. The, stratigraphic age estimates may well be correct. The fact that the $T_{\text {Th }} 230 / \mathrm{U}^{234}$ ratios in these shells lack internal consistency rules out any possibility of calculating absolute ages from these ratios.

To account for these results we assume that the original trace element compositions including the thorium and uranium contents of these shells have been altered by contact with ground waters.

Excess $T h^{230}$ in a shell (USSR-F-1) in which there is no evidence of recrystallization seems surprising but has been observed before (see, for example, sample Alas.-F-D-1116, Table 12) and has been discussed in some detail by Blanchard -who comments as follows: 65

"The following. hypothesis is offered as an explanation for the presence of excess Th230.... Acidic ground waters (rain.water-, etc.) percolating through -.. silt dissolve uranium and thorium. These waters then react with the shells $\left(\mathrm{CaCO}_{3}\right)$. The reaction leads to precipitation of thorium, and possibly uranium. Assuming that the uranium in the ground waters is in the +6 oxidation state the reaction with $\mathrm{CaCO}_{3}$ favors precipitation of thorium over uranium, thus increasing the Th - U ratio in the shell.."'

\section{CLOSED SYSTEM VER SUS OPEN SYSTEM CONDITIONS}

From the data presented thus far it is evident that the fossil mollusks that were analyzed generally fail to satisfy the criteria that have been set as tests of closed system conditions. As has already been indicated (Table 8), fossil coral samples come closer. to obeying these criteria. 66

65.R. L. Blanchard, Thesis, op. cito, P. 56

660. L. Thurber, W. S. Broecker, R. L. Blanchard, H. A. Potratz, op. cit. 
In Table 12 data on a typical coral sample, Mu-7-34, which shows no evidence of open system conditions, are compared with data for a.fossil mollusk, Alas.-F-D-1116, which failes to meet any of the criteria and is obviously an open system.

These mollusk shells, collected from the Intermediate Beach near Nome, Alaska and submitted by D. M. Hopkins, U. S. Geological Survey, consisted of a mixture of small and large sea shells, all showing evidence of weathering. The deposit from which these shells were collected is presumed to have been laid down during the Aftonian interglacial interval. These shells were exposed from 14 to 24 years on a "tailings-pile" of a placer-gold mine prior to collection in 1959. The pre-mining history of the shell sample is described by D. M. Hopkins as follows: 67

"The sediments beneath the coastal plain at. Nome are generally perennially frozen to bedrock, but in some places a layer of sediment resting immediately upon bedrock is thawed and contains cipculating ground water. Evidence in the region indicates that the perennially frozen ground probably thawed out completely during the last (Sanamon) interglacial cycle. Thus, specimen D-1116 probably has been subjected to thawing temperatures for at least a few tens of thousands of years of its history and will have been in contact with circulating.ground water during that interval."

It is not unreasonable to assume that the trace element composition of these shells may have been considerably altered by the prolonged contact with circulating waters and possibly also by the recent exposure to direct weathering.

The other sample in Tabie 12, sample MLS \# 1, is from a Mississippi Lime Company mine near Ste. Genevieve, Missouri. The oolitic portion of the Spergen formation from which this sample was taken lies about 160 feet

67D. M. Hopkins, personal communication (1962) 
Table 12. Closed System versus Open System Conditions in Fossil Marine Carbonates

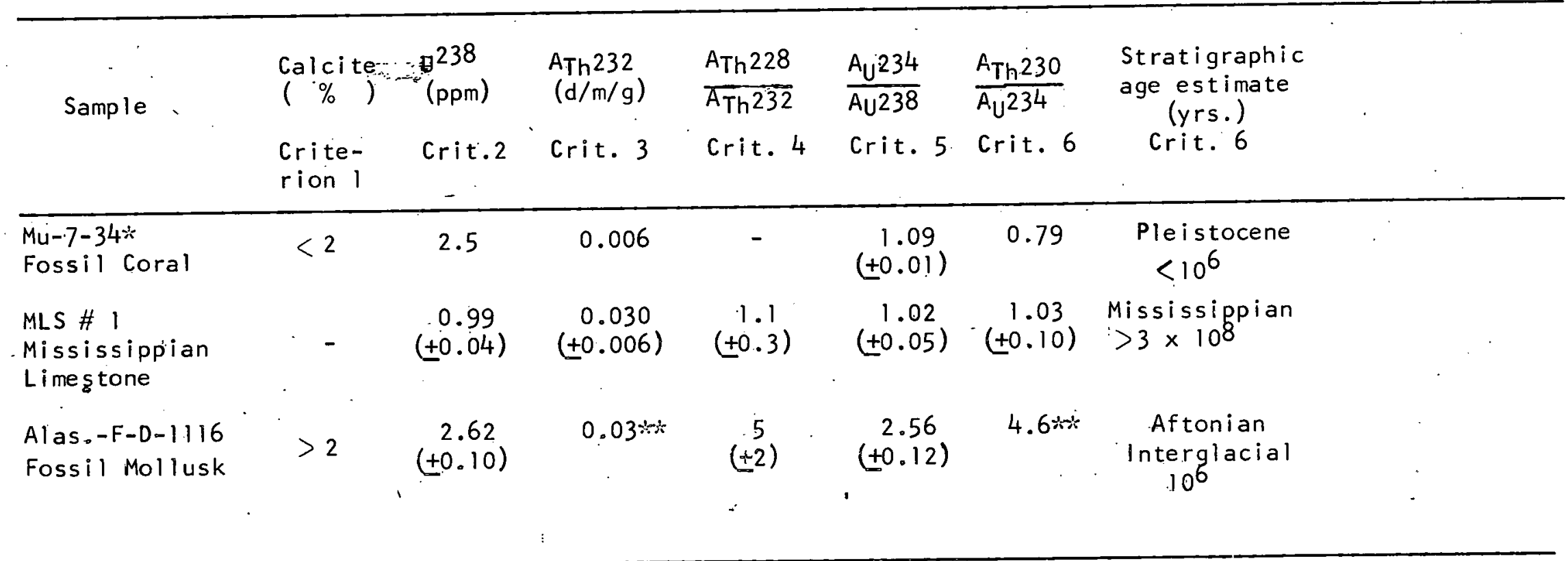

* Data on this coral sample are from Thurber, Broecker, Blanchard and Potratz, Science 149, 56 (1965).

* Calculated from data in Blanchard's thesis $\left(A_{T h} 228+A_{T h} 232\right.$ and $\left.A_{T h} 230 / A_{U} 238\right)$ using our measured values of $A_{U} 234 / A_{U} 238$ and $A_{T h} 228 / A_{T h} 232$ for this sample. 
below the surface. Above it lies gray Spergen 1 imestone and above this a stratum of $s t$. Louis limestone about 100 feet in thickness.68 Early in the geologic history of this material while original marine carbonate was being consolidated into limestone the system was probably open, and though the mineralogy of this sample has not been investigated it is not unreasonable to assume that the material is mainly calcite. 69 During, Pleistocene and recent times, however, it seems. likely that closed system conditions have prevailed. The $U^{234} / \mathrm{U}^{238}, \mathrm{Th}^{228} / \mathrm{Th}^{232}$ and $T^{230} / \mathrm{U}^{234}$ activity ratios bear out this assumption.

68 J. M. Weller and S. St. Clair, Mo. Bureau of Geology and Mines, Vol. 22, 2nd Series (1928)

69J. K. Osmond, J. R. Carpenter, and H. L. Windom, op. çit. 


\section{VI, SUMMARY}

Work previously reported indicates that the extent of disequilibrium between $\mathrm{Th}^{230}$ and $\mathrm{U}^{234}$ may be used as a measure of age of corals and oolites that have formed and remain in a marine environment. The information obtained is, however, of limited use because of the limited distribution of these materials and because of the difficulty of collecting many significant samples. The present work relates to an attempt to extend the scope of the $\mathrm{Th}^{230} / \mathrm{U}^{234}$ dating method by applying it to marine mollusks collected from terrestrial environments..

If reliable absolute ages are to be obtained from $\mathrm{Th}^{230} / \mathrm{U}^{234}$ ratios three conditions must be satisfied. (1) the original marine-deposited calcium carbonate must contain a measurable amount of uranium; (2) it must be initially free of $\operatorname{Th}^{230}$; and (3) the specimen must, during aging, behave as a closed system.

Earlier work has shown that the first two conditions are satisfied in shells of living marine mollusks and in marine shells that have been deposited during recent times. It is not unreasonable to assume that fossil marine shells also were originally free of Th230. Whether or not closed system conditions have prevailed in a fossil specimen during its entire history can probably never be established with certainty. One may, however, set criteria which are consistent with closed system conditions and reject all specimens which fail to meet these criteria. In judging the reliability of $\mathrm{Th}^{230} / \mathrm{U}^{234}$ ages of fossil marine mollusks the following criteria were used.

(1.) The sample should show no evidence of recrystallization.

(2) The uranium content of the fossil should not differ greatly from that of it's modern counterpart. 


\section{$-45-$}

(3) The Th232 content of the fossil should not differ greatly from that of its modern :counterpart.

(4) The $\mathrm{Th}^{228} / \mathrm{Th}^{232}$ activity ratio should be 1.0 .

(5) The $U^{234} / U^{238}$ activity ratio: corrected for decay of the excess $\mathrm{U}^{234}$, should fall within the range of $U^{234} / \mathrm{U}^{238}$ activity ratios in modern marine sheils.

(6) $\mathrm{Th}^{230} / \mathrm{U}^{234}$ ages should be consistent with stratigraphic data.

From the results obtained in. this work one may conclude that age determination of fossil marine carbonates by uranium decay series disequilibrium measurements, while apparently applicable, in certain instances, to fossil corals and possibly other fossil marine carbonates that have formed and have remained in a marine environment, does not yield consistent results when applied to fossil marine mollusks collected from terrestrial environments, Data obtained, in isotopic uranium and thorium analyses indicate open system conditions in these fossil mollusks. Stratigraphically" ." equiyalent samples collected from a marine terrace near Santa Cruz, California gave varying $-T^{230} / \mathrm{U}^{234}$ activity ratios in the range 0.14 to $0.51 \%$ Th $230 / \mathrm{U}^{234}$ ratios in fossil shells from deposits associated with. Anzhu. 11 . Karginian, Kazant.sevian and Sanchugovian transgressions in the USSR are not consistent with stratigraphic age estimates. Fossil mollusks contain more Th $232 .$. than do modern mollusks. indicating. that this nuclide, presumably accompanied by unknown amounts of $\mathrm{Th}^{230}$ entered the shells after they were deposited. $\mathrm{Th}^{228} / \mathrm{Th}^{232}$ activity ratios greater than 1.0 observed in most of the fossil specimens indicate open system conditions. The $u^{238}$ concentration in many fossil moliusks is higher than in modern shells. and $U^{234} / U^{238}$ ratios in some fossil specimens as compared to $u^{234} / \mathrm{u}^{238}$ ratios in modern shells also indicate open system conditions 
$-46-$

in. the fossils.

Table 13 summarizes experimental data that were obtained on fossil shells from California, Russia and Greenland. These data are compared with data based on criteria for closed system conditions. Only one sample (USSR-F-4) comes close to meeting all criteria. In this sample the absolute age calculated from the $\mathrm{Th}^{230} / \mathrm{U}^{234}$. ratio agrees with the stratigraphic age estimate. The agreement may well be fortuitous. 
Table 13 - Summary

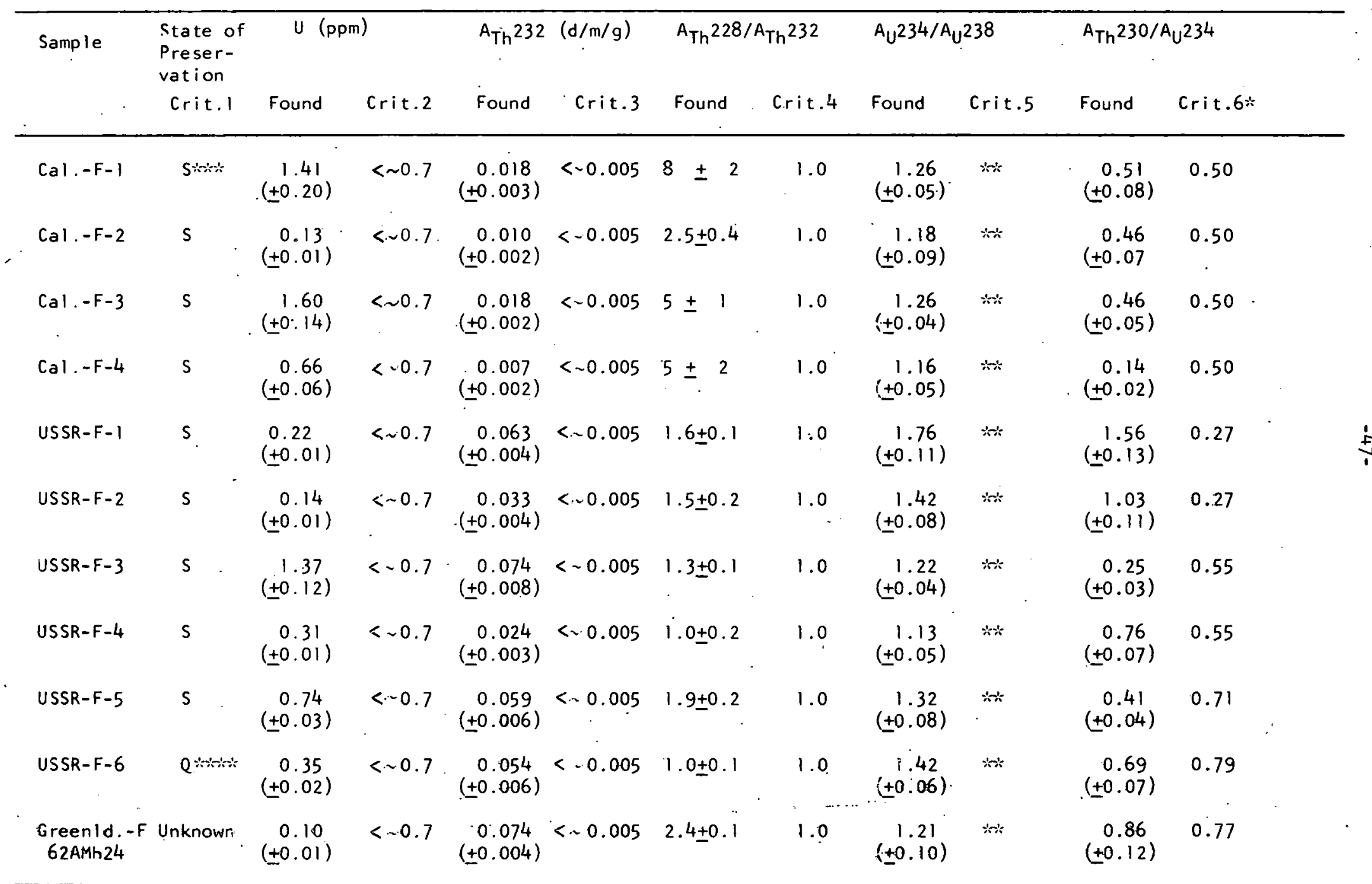

* The $T^{230 / U^{2}} 32$ activity ratios listed under criterion 6 were calculated from stratigraphic age estimates assuming closed system conditions, $A$ O $230=0$, and $A_{U} 234 / A_{U} 238=1.17$.

$\therefore$ This ratio.should be in the range $1.00^{2}-1.27$.

S = satisfactory.

a $=$ questionable. 
$-4 \dot{8}-$

\section{APPENDIX 1 - PREPARATION OF SAMPLES}

\section{CLEANING PROCESS}

The shells are first scrubbed with a hard bristle brush and distilled water to remove silt and clay and then cleaned with detergent solution and distilled water in a supersonic cleaner.* After the shells are thoroughly cleaned, they are dried and crushed to a fine powder.

\section{DISSOLVING PROCESS}

100.0 gram of the sample is dissolved by adding concentrated $\mathrm{HNO}_{3}$ dropwise..untill no further foaming is observed. Fifty milliliters of concentrated $\mathrm{HNO}_{3}$ is added and the solution. is heated to fumes and digested for two hours to oxidize the organic material present. The solution. is then diluted to $500 \mathrm{ml}$. with $2 \mathrm{M} \mathrm{HNO}_{3}$ in a $500 \mathrm{ml}$. volumetric flask.

*SONOGEN Automatic Cleaner, Cole-Parmer Instrument \& Equipment Co., Chicago, 111 . 


\section{$\because \quad-49-$ \\ APPENDIX $\|$ - PROCEDURES}

1. ISOTOPIC THORIUM AND URANIUM ANALYSIS

Alpha spectrometry is used for the isotopic analysis of thorium and uranium.

For this work it is important to have very thin sources in order to get a good peak resolution. The electrodeposition technique is used for preparing these sources.

It is also important to separate thorium from uranium because of the similarity in energy of the alpha particles emitted by $\operatorname{Th}^{230}(4.69 \mathrm{Mev}$.) to, those emitted by $U^{234}(4.72 \mathrm{Mev}, 2,47 \mathrm{Mev}$.$) .$

The anion exchange technique is used for the separation of thorium from uranium. Rather thorough investigations have been made on the adsorption of element's on anion.exchange resins. Some results of these studies have been published and are reproduced here. Figure 4 is for a chloride system, 70 and Figure 5 for a nitrate system.71 The failure of thorium to form anionic chloride complexes, to an appreciable extent, can be utilized to separate it from uranium. The separation procedure is summarized as fol lows:

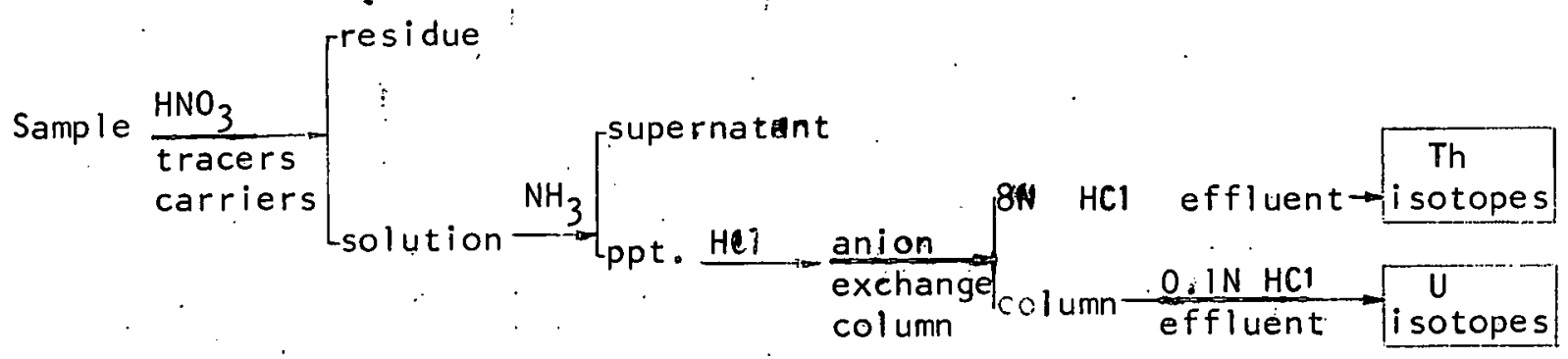

70K. A. Kraus and F. Nelson, Proc.. First Int. Conf. on the Peaceful Uses of Atomic Energy, Geneva,. 1, 113-125 (1955)

$7 l_{R}$. F. Buchanan and J. P. Faris, Proc. Int. Atomic Energy Agency, Copenhagen, September (1960);or Radioisotopes in the Physical Sciences and Industry, vol. 11, 361 (1962) 


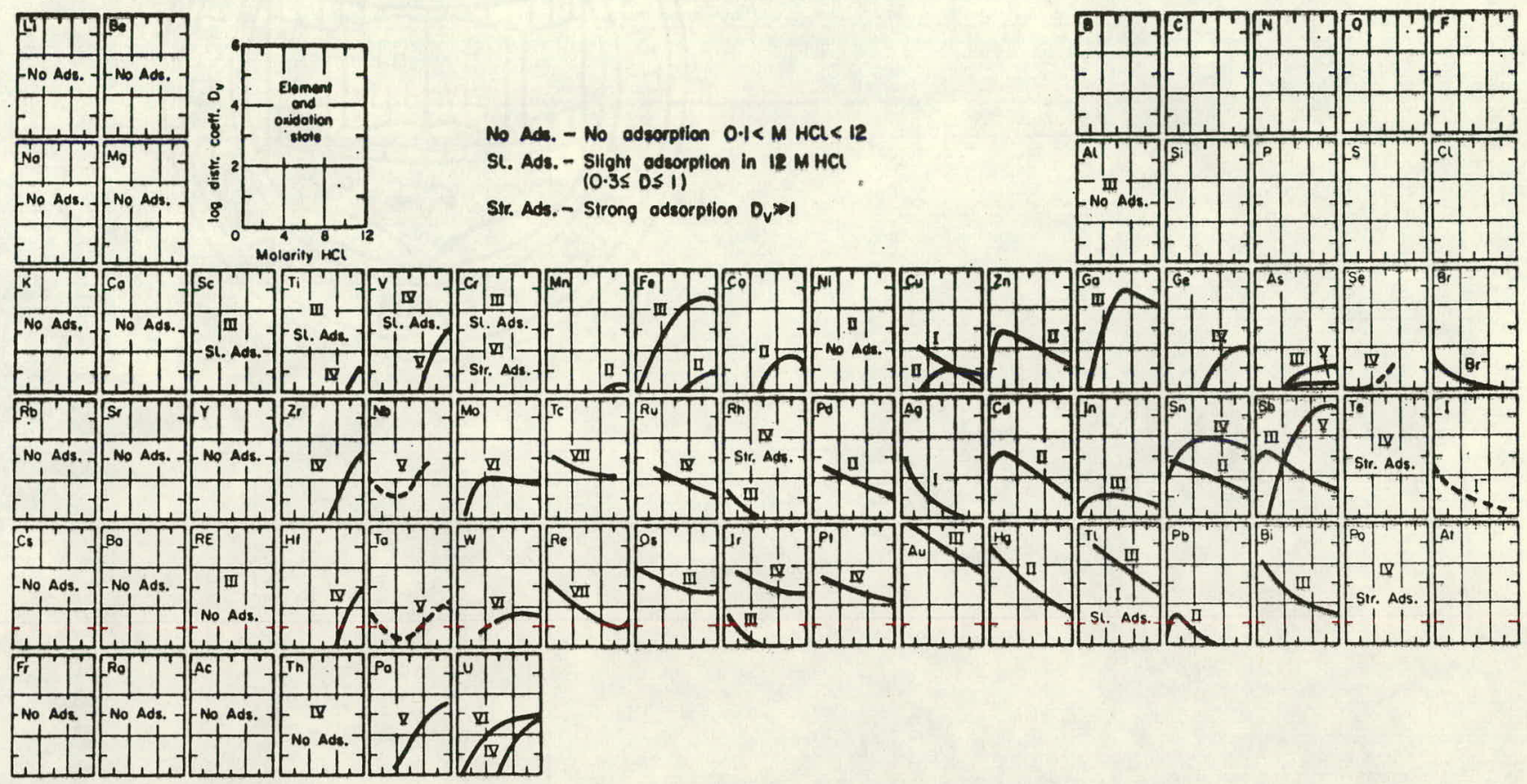

Figure 4. Adsorption of the Elements from $\mathrm{HCl}$ on strongly Basic Anion Exchange Resin

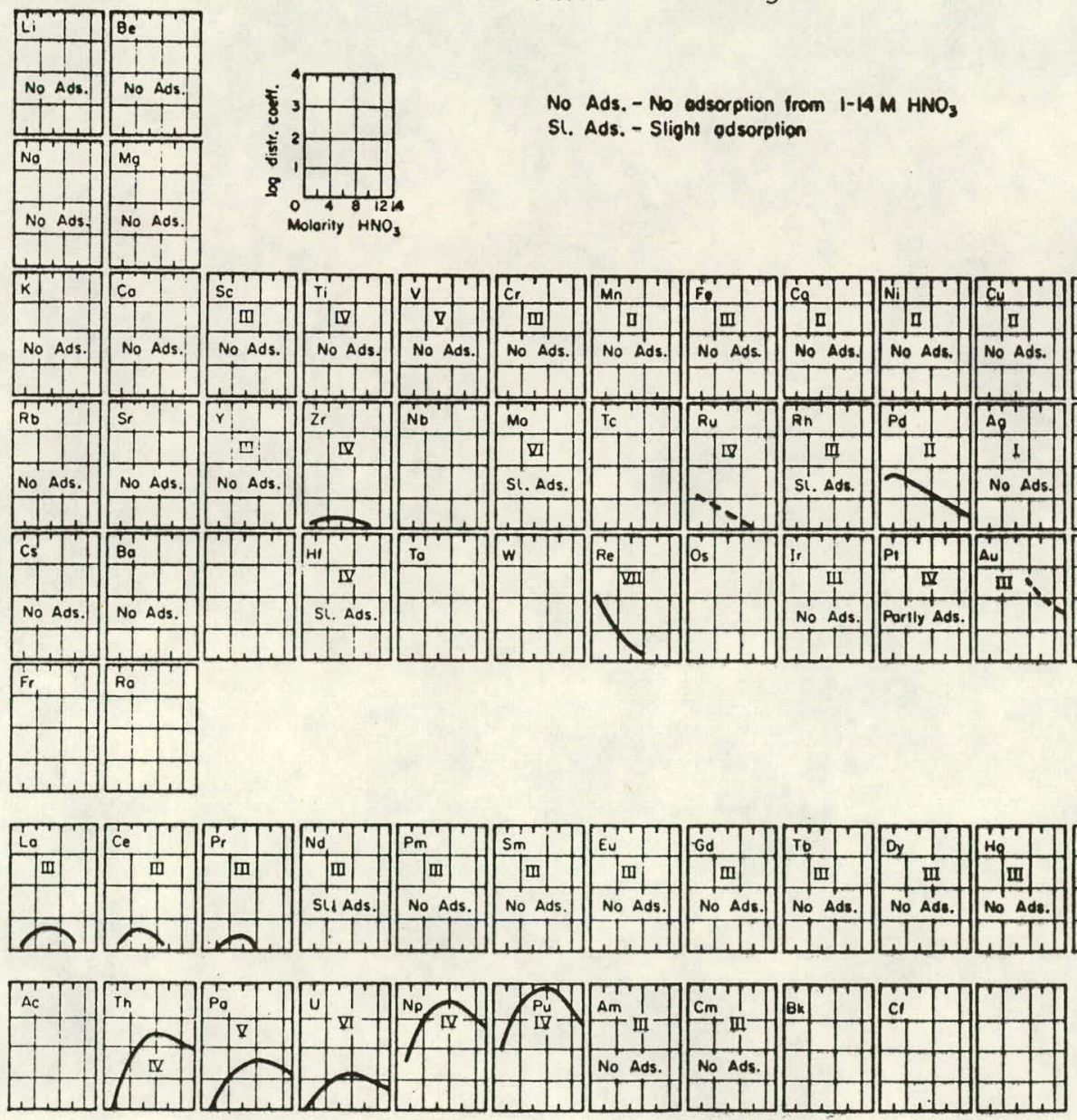

\begin{tabular}{|c|c|c|c|}
\hline 11 & c) & {$\left[\mathrm{NT}^{2}\right.$} & \begin{tabular}{|l|l|}
0 \\
\end{tabular} \\
\hline & & & \\
\hline$\Delta_{d}$ & & & \\
\hline & & & \\
\hline$i$ & 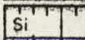 & {$[7$} & \\
\hline III & & 7 & \\
\hline No Ads. & & No Ads. & \\
\hline 71 & & & \\
\hline im & 69 & As & \\
\hline No Ads. & & No Ads. & \\
\hline & & & \\
\hline & sn & sb & $\frac{10}{10}$ \\
\hline 叫 & \begin{tabular}{|l|}
$\pi$ \\
\end{tabular} & 8 & $\mid \overline{\mid l}$ \\
\hline No Ads. & St. Ads & No A Ads. & No Ads. \\
\hline لـ & 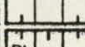 & & \\
\hline 11 & $\mid b^{B b}$ & & \\
\hline & SL, Ads & & \\
\hline & 11 & & \\
\hline
\end{tabular}

i.1.1. $0.3 \leq 0 \leq 1$

-

No Ads.

$-$ 


\section{A. Separation of Thorium and Uranium}

Step 1. Pipette an aliquot of sample solution (an amount equal to 20 to $50 \mathrm{gm}$. of sample) into a beaker. Ádd tracers in known amounts (approximately 300 counts per minute of $\mathrm{Th}^{234}$ and 20 counts per minute of $\mathrm{U}^{232}$ ). Add $\mathrm{l} \mathrm{mg}$. of $\mathrm{Fe}^{+++}$and $1 / 4 \mathrm{mg}$. of $\mathrm{Al}^{+++}$carriers per gram sample. Dilute the solution to a volume of $20 \mathrm{ml}$. per gram sample. Boil the solution for ten minutes and make up to the volume with distilled water. (Note 1)

Step 2. Allow the solution to cool $\therefore$ Add carbonate-free $\mathrm{NH}_{4} \mathrm{OH}$ dropwise until pH=8. Digest the mixture for ten minutes. Let the $\mathrm{Fe}(\mathrm{OH})_{3}$ and $\mathrm{Al}(\mathrm{OH})_{3}$ precipitates stand for an hour, centrifuge in a $250 \mathrm{ml}$. centrifuge bottle and decant. (Note 2)

Step 3. Dissolve the hydroxide precipitates in $1 \mathrm{ml}$. of $8 \mathrm{~N} \mathrm{HCl}$ per gram sample and transfer quantitatively into a $90 \mathrm{ml}$. centrifuge tube. Add carbonate-free $\mathrm{NH}_{4} \mathrm{OH}$ dropwise until $\mathrm{pH}=8$. Put the centrifuge tube in a Temp-Block module heater* and digest the mixture for 10 minutes or until the precipitate floats on the surface. Cool, centrifuge and decant. Step 4. Reprecipitate $\mathrm{Fe}(\mathrm{OH})_{3}$ as in Step 3. Wash precipitate once with distilled water. Dissolve the precipitate with $0.5 \mathrm{ml}$. of concentrated $\mathrm{HCl}$ and rinse down the sides of the centrifuge tube with $8 \mathrm{~N} \mathrm{HCl}$. At this point if there is any insoluble residue present, heat the residue in three successive portions of $1 \mathrm{ml}$. of $6 \mathrm{~N} \mathrm{HCl}$ with a centrifugation between each heating and combine the supernatants with the solution obtained above. (Note 3)

Step 5. Transfer the $8 \mathrm{~N} \mathrm{HCl}$ solution quantitatively to the top of

*Temp-Block Module Heater, Lab-Line Instruments, Inc., Melrose Park, lllinois. 
a $4 \mathrm{~mm}$. $\times 7 \mathrm{~cm}$., Dowex 1-X8,200-400 mesh, conditioned, an ion exchange column and allow the solution to flow through under atmospheric pressure. (Note 4)

Step 6. When the liquid level reaches the resin, wash the column with three $2 \mathrm{ml}$. portions of $8 \mathrm{~N} \mathrm{HCl}$, then flush with $5 \mathrm{ml}$. of $8 \mathrm{~N} \mathrm{HCl}$. Uranium and iron are adsorbed on the column and thorium and aluminum are i.n the effluent. Thorium and uranium are purified by the following procedures.

\section{B. Purification and Electrodepositlon of Thorium}

Step 1. To the thorium-bearing $8 \mathrm{~N} \mathrm{HCl}$ effluent of the anion exchange column add $5 \mathrm{mg}$ of $\mathrm{Fe}^{+++}$carrier. Heat the solution for ten minutes. and add $\mathrm{NH}_{4} \mathrm{OH}$ dropwise to precipitate aluminum and iron hydroxides and coprecipi.tate.thorium. Put the centrifuge tube in a Temp-Block module heater and digest the mixture for ten minutes. Cool, centrifuge and decant..

Step 2.. Dissolve the precipltate in .10.ml. of: $7 \mathrm{M} \mathrm{HNO}_{3}$ and reprecipitate the hydroxides as above. Wash precipitate once with distilled water. (Note 5)

Step 3. Dissolve the precipitate in $1 / 2 \mathrm{ml}$. of conc. $\mathrm{HNO}_{3}$ and rinse down the sides of the centrifuge tube with $7 \mathrm{M}^{-\mathrm{HNO}_{3}}$. Transfer the $7 \mathrm{M} \mathrm{HNO}{ }_{3}$ solutian to the top of a $3 \mathrm{~mm} . \times 4 \mathrm{~cm}$., Dowex 1-x8, 200-400 mesh, nitrate-form, conditioned, anion-exchange column and allow the solution to flow through under atmospheric pressure. (Note 6)

Step 4. When the liquid level reaches the resin, wash the column with three $2 \mathrm{ml}$. portions of $7 \mathrm{M} . \mathrm{HNO}_{3}$, then flush with $3 \mathrm{ml}$. of $7 \mathrm{M} \mathrm{HNO}_{3}$. Aluminum and iron are in the effluent and thorium is adsorbed on the column.

Step 5. Elute thorium from the column with $7 \mathrm{mil}$. of $1 \mathrm{~N} \mathrm{HCl}$. Collect the effluent in a $30 \mathrm{ml}$. beaker. Evaporate the solution to near dryness 
several times with concentrated $\mathrm{HCl}$.

Step 6. Take up the residue in $1 \mathrm{ml}$. of $1 \mathrm{~N} \mathrm{HCl}$ and transfer it quantitatively into an.electroplating cell with $6 \mathrm{ml}$. of saturated $\mathrm{NH}_{4} \mathrm{Cl}$ solution. (Note 7)

Step 7. Electroplate thorium isotopes onto a one inch diameter platinum planchet (cathode) at 3.5-4.0 v.., 0.3 amp. for two hours. Adjust the pH to 2 every thirty minutes with a few drops of $\mathrm{NH}_{4} \mathrm{OH}$. At the end of electroplating, add several drops of $\mathrm{NH}_{4} \mathrm{OH}$. to make the solution basic. Whi le the voltage is still on, pipette out half the solution from ithe cel1, add distilled water to full.. Repeat this process several times unt.il the current is zero. (Note 8)

Step 8. Turn off the current and remove the platinum planchet from the electroplating: cell. Peel off the rubber cement and wash the planchet with water. Dry under a heat lamp and heat the planchet to. redness over a Bunsen burner.

Step 9. Count the alpha and the beta activities of thorium isotopes on the planchet by proportional counters and analyze the alpha particle energies by. alpha spectrometry.

\section{Purification and Electrodeposition of Uranium}

Step 1. Elute uranium from the uranium-bearing anion exchange column with $10 \mathrm{ml}$. of $0.1 \mathrm{~N} \mathrm{HCl}$. Collect the effluent in a $30 \mathrm{ml}$. beaker and evaporate the solution to dryness.

Step 2. Take up residue in $8 \mathrm{~N} \mathrm{HCl}$ and transfer the solution quantitatively into a $50 \mathrm{ml}$. graduated test tube with $10 \mathrm{ml}$. of $8 \mathrm{~N} \mathrm{HCl}$. Add $10 \mathrm{ml}$. of isopropyl ether, cap the test tube tightly with a polyethylene stopper, mix the two phases with a Vortex mixer for three "minutes 
and centrifuge. Discard the ether layer. Repeat the isopropyl ether extraction of iron twice: In the second or the third ether extraction, if the yellow collor of iron is not extracted into the ether layer add a few drops of concentrated $\mathrm{HCl}$ and shake the mixture again.. After the third ether layer is discarded, transfer the aqueous layer quantitatively into a $30 \mathrm{ml}$, beaker and evaporate to almost dryness: Fume with concentrated $\mathrm{HNO}_{3}$ several times until all the chloride is converted to nitrate. (Note 9)

Step 3. Take up the residue in $2 \mathrm{ml}$. of $0.1 \mathrm{~N} \mathrm{HNO}_{3}$ and transfer the solution quantitatively into an electroplating cell with' $5 \mathrm{ml}$. of $4 \mathrm{M} \cdot \mathrm{NaNO}_{3} \cdot \quad($ Note 7$)$

Step 4. Electroplate uranium isotopes onto a one inch diameter stainless steel planchet (cathode) at 6.0-6.5 v.,1.5 amp. for two hours. Adjust the $\mathrm{pH}$ to 2 every fifteen minutes with a few drops of $4 \mathrm{~N} \mathrm{HNO}_{3}$. After the completion of electroplating, pipette out half the solution from the cell and add distilled water to full. Repeat this process several times until the current is zero (Note 8)

Step 5. Turn off the current and remove the stainless steel planchet from the electroplating cell. Peel off the rubber cement and wash the planchet with distilled water. Dry the planchet under a heat lamp.

Step 6. Count the alpha activity of uranium isotopes on the planchet with a proportional counter and analyze the alpha particle energies by alpha spectrometry. (Note 10)

\section{Count ing and Alpha Spectrometry of Thorium and Uranium Isotopes}

The instruments used for the measurement of gross alpha and beta activities are: 

A) Nuclear Measurements Corp. decade scaler Model DS - IA.
B) Nuclear Measurements Corp. windowless gas-flow proportional counter Model:PCC-IIA (lead shield) for beta measurements and Model PCC-1OA (no lead shield) for alpha measurements. P-10. counter gas which consists of. $90 \%$ argon and $10 \%$ methane is used.

The instruments used for alpha pulse height analysis are:
A) Oak Ridge Technical Enterprised Corp. Model 101-201 low noise amplifier system.
B) Oak Ridge Technical Enterprised Corp. silicon surface barrier semi- conductor radiation detector.

C) Nuclear Diode vacuum chamber.

D) RIDL Model 34-12 400 channcel pulse height analyzer.

The source is placed approximately $5 \mathrm{~mm}$ below the detector. The chamber is then evacuated... Alpha particles impingeing on the detector generate electrical pull ses proportional... to the ir energy... The pulses are amplified and fed into a multi-channel analyzer which records the number of pulses received in each energy interval. The data stored by: the analyzer are read out by using an: IBM typewriter modified for this purpose. Energy calibration of the analyzer is accomplished.by the use of al pha standards. A block diagram of the circuit used for alpha spectrometry is shown in Figure 6 . 
To Detector

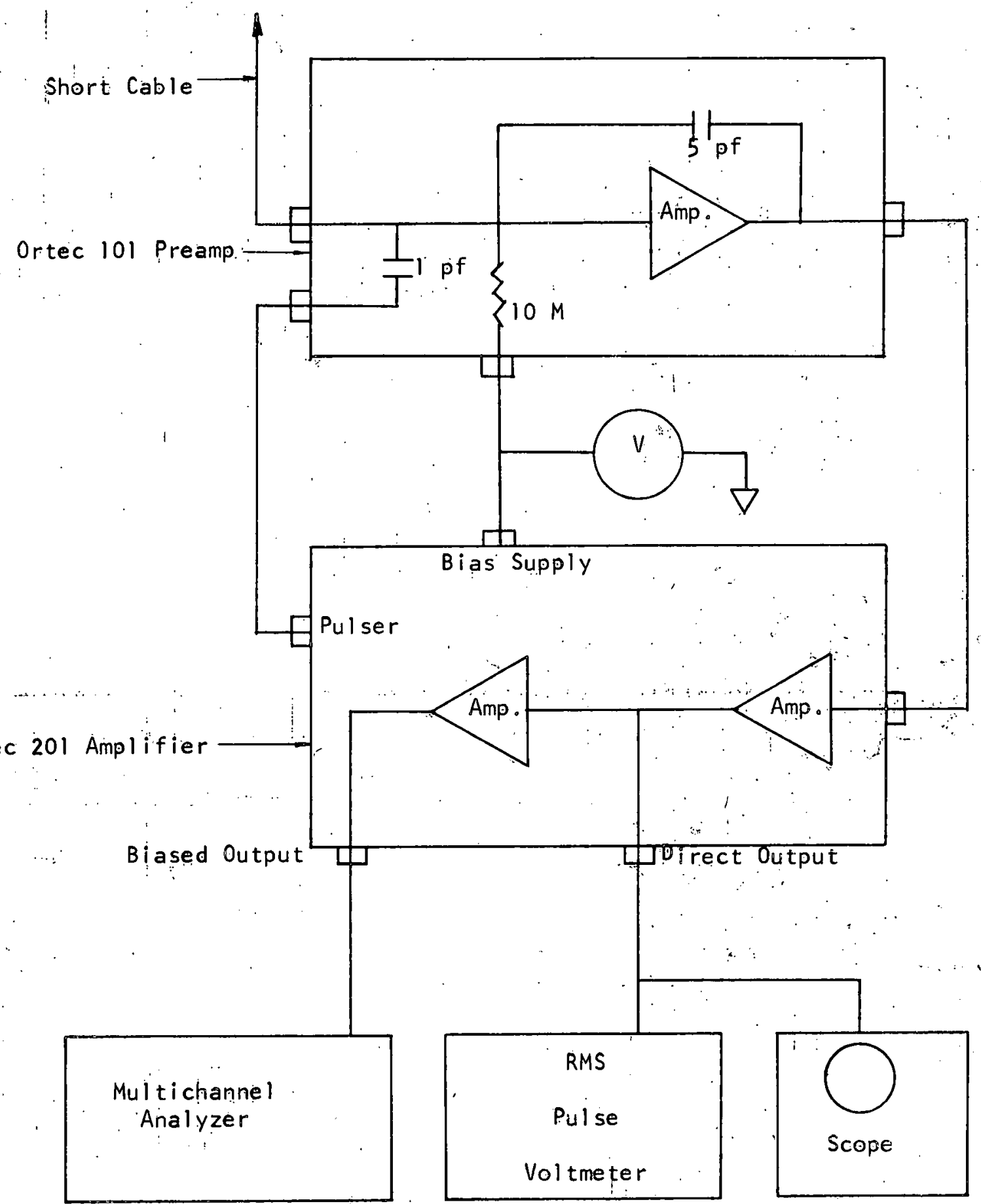

Figure 6. Block Diagram of the Circuit Used for Alpha Spectrometry. 


\section{E. Calculation of I sotopic Thorlum and Uranium Contents}

A) Thorium Spectra

Table 14 gives the energy values of the alpha particles of the naturally occuring thorium alpha emitters and those emitted by the daughters of $\mathrm{Th}^{228}$.

Figure 7 shows the alpha-spectrum of thorium isotopes isolated from sample USSR-F-3. The peaks beyond channel number 170 are the peaks of $\mathrm{Th}^{228}$ daughters which have grown in. The alpha particles from the small amount of $\mathrm{Th}^{227}$ activity present are not resolved but contribute to

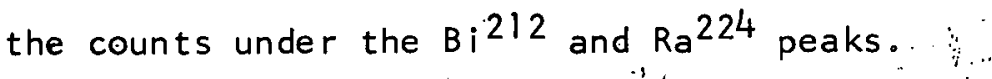

The yield of thorium is calculated from the recovery of the beta emitting $\mathrm{Th}^{234}$ tracer.

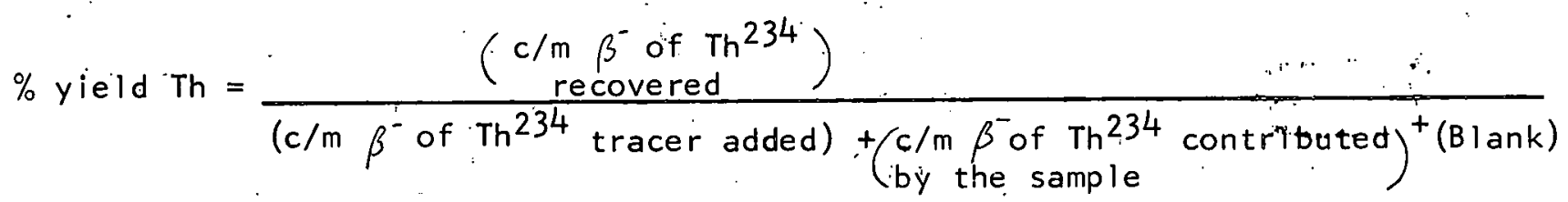

Counts per -minute beta of $\mathrm{Th}^{234}$ contributed by the sample is calculated from the activity of $\mathrm{U}^{238}$ by assuming $\mathrm{U} 238$ and $\mathrm{Th}^{234}$ in the sample are in secular equilibrium. This correction is rather small, on the order of less than one: percent... The correction for the blank is even smaller. The sums for $\operatorname{Th}^{232}, \mathrm{Th}^{230}$ and $\mathrm{Th}^{228}$ peaks are computed and the following corrections are made:

1) The correction for background.

2)... The correction for blank.

3) The correction for the $\mathrm{Ra}^{224}$ which appears in the $\mathrm{Th}^{228}$ region. From Table 14-we see that. 4.9 per cent of Ra224. alphas are emitted with an amount of energy such thit they are registered under the $T^{228}$ peak. Therefore, the counts under. the $\mathrm{Ra}^{224}$ peak are summed up and 4.9/95.1 times this sum is. subtracted from the $T^{228}$ peak sum. After the 
Table $\cdot 14$

The Nuclear Characteristics of Certain Thorium Isotopes

and Daughters of $\mathrm{Th}^{228}$

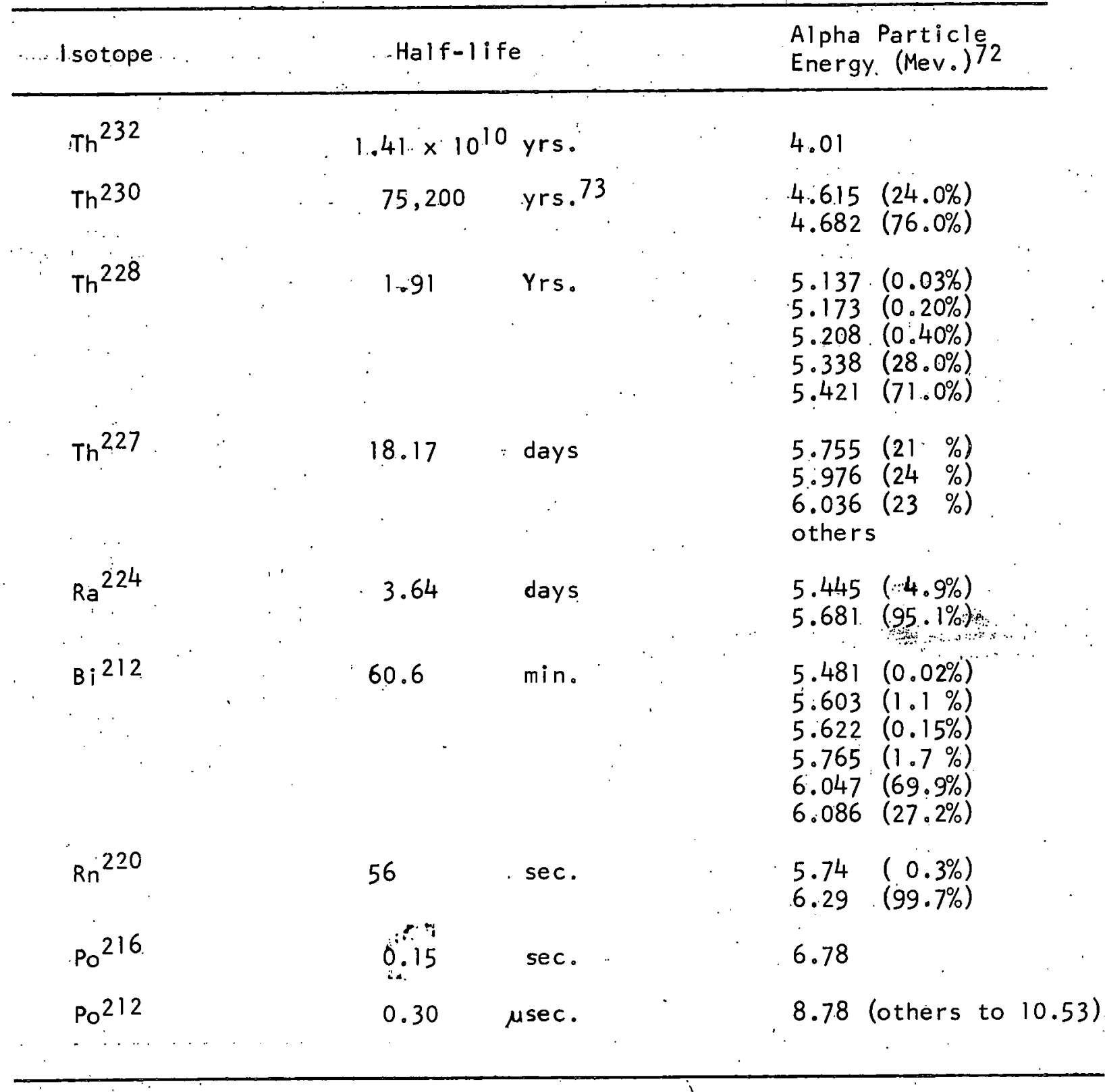

$72 \mathrm{D}$. Strominger, J. M. Hollander, and G. T. Seaborg, Rev. of Mod. Phys. 30, : 78.8-81.8 (1958)

$73 R_{\text {. W. Wt }}$ Atree et al., Canadian J. Phys., 40, 194:(1962) 


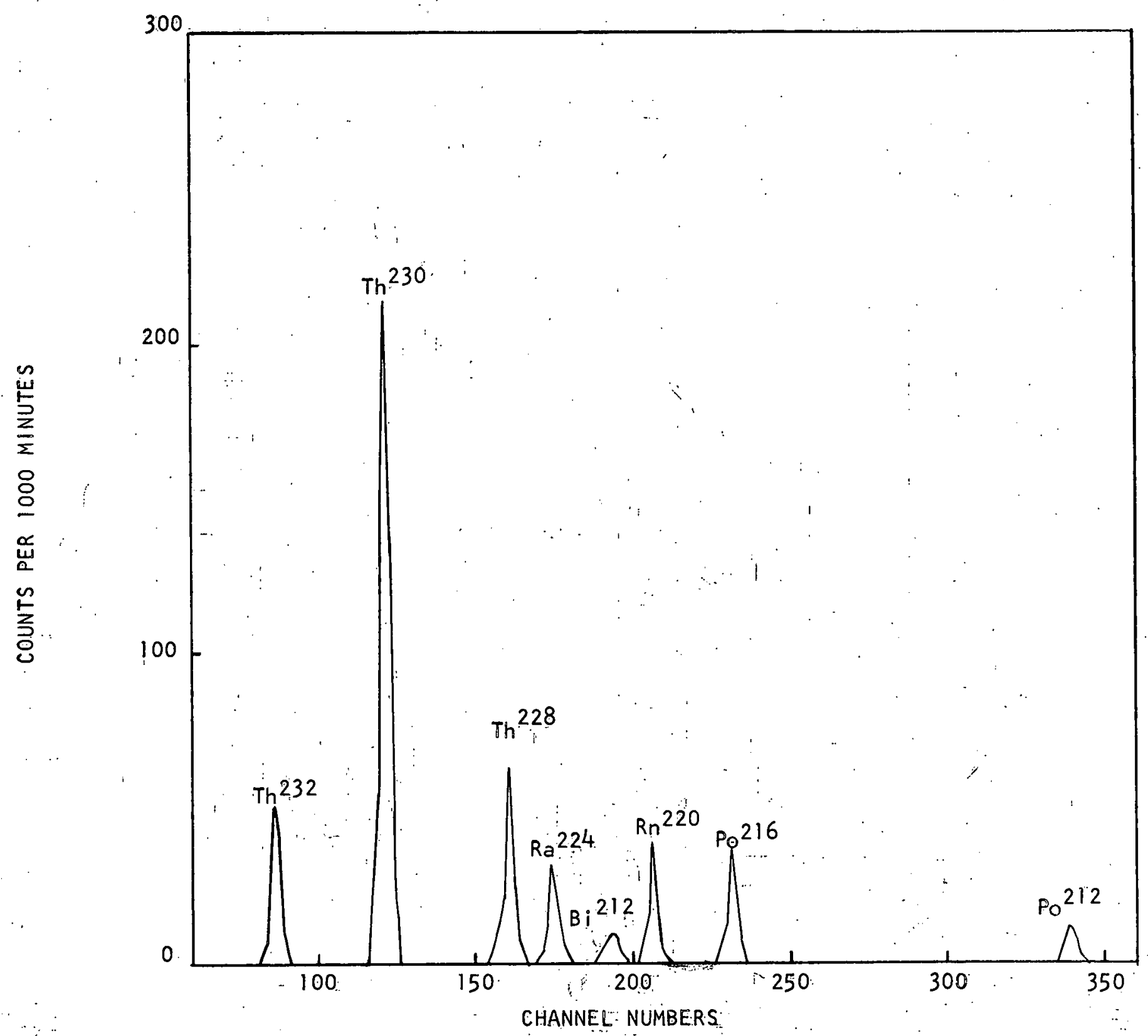

Figure 7. The Alpha-Spectrum of Thorium Tsotopes-I solated from Sample USSR-F-3. 
corrections are made, the net number of counts of each thorium peak is obtained and the percent it represents of the total number of counts under all the peaks in the spectrum.can be calculated. If the total alpha activity of the thorium source in disintegrations per minute per gram of sample, at the time of al.pha pul.se height analysis is represented by $A$ and the activity of a thorium isotope by $A_{i}$, then

$$
\begin{aligned}
& A_{i} \ldots=\frac{A \times \text { the percent of the total alpha activity contributed) }}{\text { by the isotope }} \\
& (\mathrm{d} / \mathrm{m} \% \mathrm{~g})=\frac{\text { (the percent yield of thorium) }}{\text { An example of the calculation of isotopic thorium compositions is }}
\end{aligned}
$$
given below:

We ight of sample (USSR-F-3) = $12.17 \mathrm{gm}$.

Uranium content of the sample $=1.37 \pm 0.12 \mathrm{ppm}$.

$A_{U} 238=1.37 \times 12.17 \times 0.735=12.2$ dis. $/ \mathrm{min}$.

$\mathrm{c} / \mathrm{m} \beta^{-}$of $\mathrm{Th}^{234}$ recovered $=509 \pm 5$

$\mathrm{c} / \mathrm{m} \beta^{-}$of $\mathrm{Th}^{234}$ tracer added $=(620 \pm 6) \times 0.8011 \%$

$\mathrm{c} / \mathrm{m} \beta^{-}$of a blank run $=1.5$

$\mathrm{c} / \mathrm{m}$ alpha at the time of alpha pulse height analysis $=4.0 \pm 0.3$

Geometry of the proportional counter $=0.50 \pm 0.01$

\begin{tabular}{|c|c|c|c|c|c|c|c|c|}
\hline \multirow{2}{*}{$\overline{T \text { Total }} \overline{T^{232}}$} & \multirow{2}{*}{ Counts } & \multirow{2}{*}{188} & \multicolumn{2}{|c|}{ Bkgd. } & \multirow{2}{*}{$\frac{\text { Blank }}{0}$} & \multirow{2}{*}{$\begin{array}{l}\text { Correction } \\
\text { for Ra-224 } \\
-\end{array}$} & \multicolumn{2}{|c|}{ Net counts of } \\
\hline & & & 0 & . & & & $T h^{232}$ & 188 \\
\hline $\mathrm{Th}^{2.30}$ & 11 & 786 & 0 & & 0 & - & $T h^{230}$ & 786 \\
\hline $\mathrm{Th}^{228 .}$ & 11 & 268 & .26 & & 0 & $5.4 \%$ & $T h^{228}$ & 237 \\
\hline $\mathrm{Ra}^{224}$ & 11 & 134 & 28 & , & 0 & - & $\mathrm{Ra}^{224}$ & 106. \\
\hline \multicolumn{2}{|c|}{$\begin{array}{l}\text { All the } \\
\text { peaks }\end{array}$} & 1786 & 109 & & 3 & - & \multicolumn{2}{|c|}{$\begin{array}{c}\text { All the } 1674 \\
\text { peaks }\end{array}$} \\
\hline
\end{tabular}

Alpha spectrum of the sample -- see Figure 7 .

$* 0.8011$ is the correction factor for $\mathrm{Th}^{234}$ decay?

in $5.4=.106 \times 4.9 / 95.1$

$77_{H}$. W. Kirby, Anal. Chem., 26, 1063-1072 (1954) 
$\%$ yield Th $=$ 509 $=101 \pm 2 . \%$

The percent of the total activity contributed by each thorium isotope is,

$$
\begin{aligned}
& \operatorname{Th}^{232}=188 / 1674=11.2 \pm 0.9 \% \\
& \operatorname{Th}^{230}=786 / 1674=47.1 \pm 2.0 \% \\
& \operatorname{Th}^{228}=236 / 1674=14.1 \pm 1.0 \%
\end{aligned}
$$

$A=$ total alpha activity at the time of alpha pulse height analysis $=2 \times 4.0 / 12.17=0.66 \pm 0.05 \mathrm{~d} / \mathrm{m} / \mathrm{g}$. Therefore the activities of each thorium isotope are:

$$
\begin{aligned}
& A_{T h}{ }^{232}=0.66 \times 0.112 / 1.00=0.074 \pm 0.008 \mathrm{~d} / \mathrm{m} / \mathrm{g} \\
& A_{T h} 230=0.66 \times 0.471 \% 1.00=0.31 \pm 0.03 \mathrm{~d} / \mathrm{m} / \mathrm{g} \\
& A_{T_{T h}}{ }^{228}=0.66 \times 0.141 / 1.00=0.093 \pm 0.009 \cdot \mathrm{d} / \mathrm{m} / \mathrm{g}
\end{aligned}
$$

B) ... U.ranium Spectra

Table 15. gives the energy values of the alpha particles emitted by certain uranium i sotopes.

Table 15

The Nuclear Characteristics of Some Uranium. I sotopes

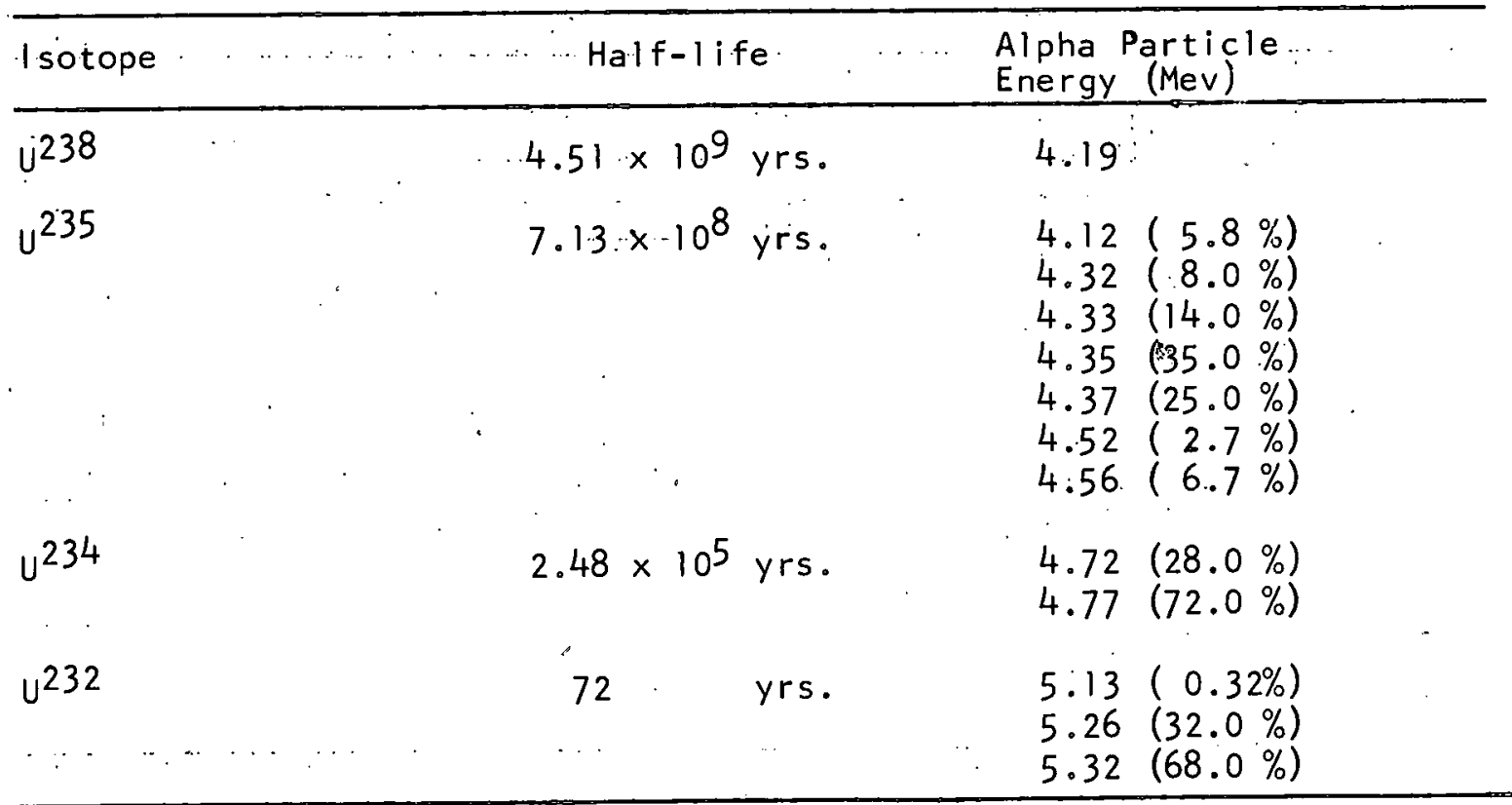




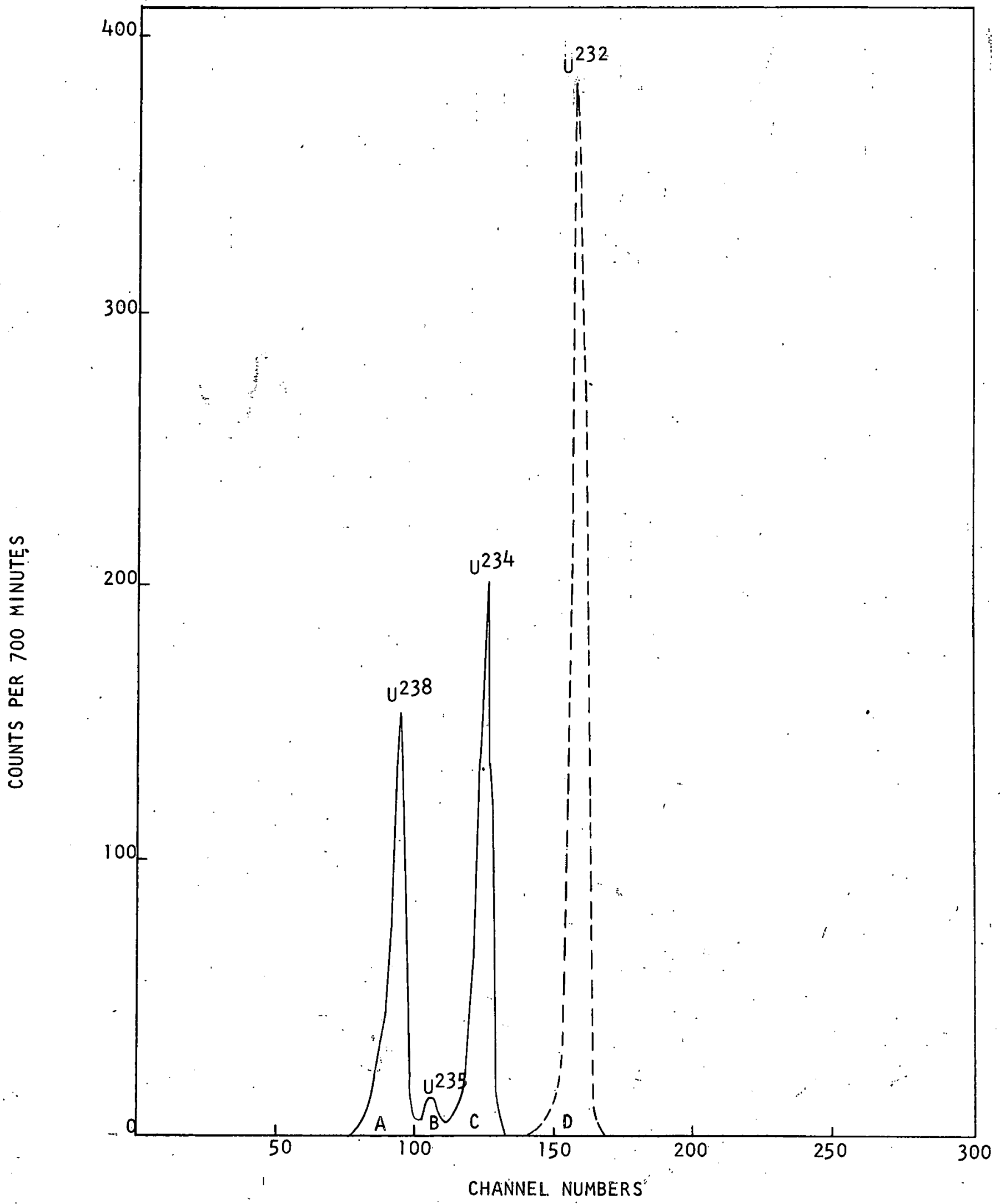

Figure 8. The Alphar-Spectrum of Uranium Isotopes isolated from Sample Cal. $-\mathrm{F}-4$. 
Figure 8. shows the alpha spectrum of uranium isotopes isolated

from sample Cal-F-4. The dashed-line peak is at the position of $U^{232}$.

This peak appears when $U^{232}$ tracer . is added to the sample.

." The sum for each uranium peak is computed and the following corrections are made.

1). The correction for background

2) The correction. for blank...

3) The correction for $U^{235}$ which appears in the $U^{238}$ peak. From Table15 we see that 5.8 per cent. of $U^{235}$ alphas are emitted with an amount of energy such that they are recorded in the $U^{238}$ peak. Therefore. $5.8 \%$ of the theoretical $U^{235}$ is subtracted from the $U^{238}$ peak sum. The theoretical $U^{235}$ count is found by wsing the value of 21.96 as the ratio of specific activities of $\mathrm{U}^{238}$ to $\mathrm{u}^{235}$ ard dividing this figure into the $u^{238}$ peak count.

4.) The correction. for the tailing of $U^{234}$ alphas. into the $U^{235}$ peak. The theoretical.value of $U^{235}$ as found above. is always, slightly lower than the experimentally ascertained $U^{235}$ activity. . The difference is ascribed to. tailing of the U.3.4 and is added to the $U^{234}$ activity.

When $U^{232}$ is run alone it shows a peak only in the $U^{232}$ region, so no correction need be made for impurities in the $U^{232}$ tracer.

If the total count under each peak in the $\mathrm{U}^{238}, \mathrm{U}^{235}, \mathrm{U}^{234}$ and $\mathrm{U}^{232}$ regions are represented by $A, B, C$, and $D$ respectively, then

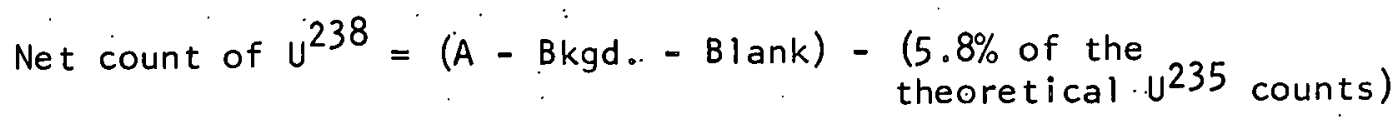
- . - . - - - - (1)

the theoretical $U^{235}$ count $=$ (net count of $U^{238}$ )/21.96

substitute (2) into (1) we obtain, 
Net count of U238 $=21.96(A-B k g d=B l a n k) / 22.02$

$\mathrm{U}^{234} \mathrm{tailing}=(\mathrm{B} .-\mathrm{Bkgd} .-\mathrm{Blank})-[($ net. count of U238)/21.96].[0.942]

$$
=(B-B k g d .-B l a n k)-[(A-B k g d . B l a n k) / 22.02] \cdot[0.942]
$$

Net count of $U^{2} 344=(C:-B k g d .-B l a n k)+\left(U^{234}\right.$ tailing $)-\ldots$ substitute (3) into (4), we obtain, Net count of $U^{234}=(C-B k g d .-B l a n k)+(B-B k g d .-B l a n k)$

$$
-[(A \ldots-. B k d g \cdot-B l a n k) / 22.02] \cdot[0.942]
$$

Net Count of $U^{232}=(D-B k g d .-B l a n k)$

From these corrected values, the activity ratios $u^{234} / u^{238}$, $U^{238} / U^{232}$ and $U^{234} / U^{232}$ are computed. By multiplying the last two ratios by disintegration: per minute $U^{232}$ added, the dpm of $U^{238}$ and $U^{234}$ in the sample are obtained. The specific activities are calculataj as follows:

$$
\begin{aligned}
A_{U} 234(d / m / g) & =\frac{\left(d p m U^{232} \text { added) (net count of } U^{234}\right)}{\left(w t \text { of sample) (net count of } U^{232}\right)} \\
A_{U} 238(d / m / g) & =\frac{\left(d p m U^{232} \text { added) (net count of } U^{238}\right)}{\left(w t . \text { of sample) (net count of } U^{232}\right)}
\end{aligned}
$$

Since 1. $\mu$ g of uranium of normal isotope abundance gives 0.735 disintegration per minutes of $u^{238}$,

$$
\frac{A_{U} 238}{0.735}=\text { ppm } U^{238} \text { in the sample. }
$$

F. Notes

Note 1. (a) $\mathrm{Th}^{234}$ tracer is prepared by périodically "milking" the same uranyl perchlorate- $\mathrm{HClO}_{4}$ solution. Mallinckrodt $A$. R. uranyl nitrate hexamydrate is used for the preparation of the uranyl perchlcrate solution. The uranyl perchlorate solution is transferred to the top of a Dowex-50-x4, 200-400 mesh cation exchange column and is allowed to flow through under atmospheric pressure. When the liquid level reaches the resin the inside of the tube is washed down, with several $1 \mathrm{ml}$. portions of $3 \mathrm{~N} \mathrm{HCl}$ until the yellow color has completely disappeared from the effluent. $3 \mathrm{ml}$. of $0.5 \mathrm{M}$ oxalic acid is added to the column and the effluent 
is collected in a $30 \mathrm{ml}$. beaker.. $5 \mathrm{ml}$. of concentrated $\mathrm{HNO}_{3}$ : is added to the beaker and the solution is heated to fumes until approximately 2 $\mathrm{ml}$. of solution remains. The solution is cooled and $2 \mathrm{mi}$. of $72 \% \mathrm{HClO}_{4}$ is added: The solution is heated to fumes of $\mathrm{HClO}_{4}$ and evaparated to a volume of $\mathrm{l} \mathrm{ml}$...After the solution has cooled d ml. of concentrated $\mathrm{HCl}$ and $2 \mathrm{ml}$. of distilled water are added. The perchlorate solution is passed through a second: Dowex-50- $\times 4$ column identical to the first. When the liquidelevel reaches the resin, the inside of the tube is washed down witheight $1 / 2 \cdot \mathrm{ml}$. portions of $3 \mathrm{~N} \cdot \mathrm{HCl}$ The. Th234 on the column is eluted

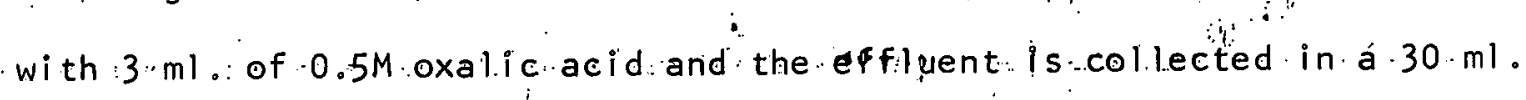
beaker...To the beaker $5 \mathrm{ml}$. of concentrated $\mathrm{HNO}_{3}$ is added, and the solution. is heated to fumes and evaporated tọ a volume of approximately $2 \mathrm{mil}$. The solution is cooled; $2 \mathrm{ml}$. of $72 \% . \mathrm{HCl} 0_{4}$. is added. The solution is. evaporated to dryness. and the residue is taken up. in $3 \mathrm{M} \mathrm{HNO}_{3}$. The final solution: is diluted to the desired $\mathrm{Th}^{2} 34$ activity with $3 \mathrm{M} \cdot \mathrm{HNO}_{3}$. T.wo: 100 lambda tracer aliquots are mounted on platinum planchets - one by evaporation and flaming, and the other by electrodeposition. The mounted sources are counted with a proportional counter. $621 \pm 6$

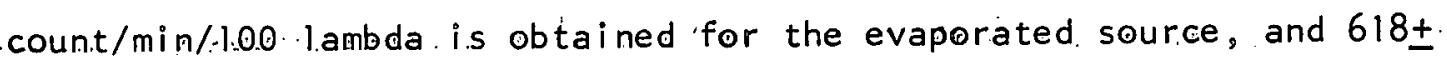
6 count/min./100.lambida for the electroplated source... The difference between the se two counts is swthin the limit of counting statistics. The average of these : two activities is compared with the $\mathrm{Th}^{2} 34$ activity recovered from the sample. to determine: the-yield of the thorium analysis. (b) $\mathrm{U}^{232}$, tracer solution: is prepared from U232, that was obtained from the Argonne National Laboratory. The tracer solution is in $4 \mathrm{~N} \cdot \mathrm{HNO}_{3}$. (c) - The solution is diluted because precipitates formed from a very concentrated solution are often in the form of extremely fine crystals with colloidal properties. 
(d) The solution is boiled to expel $\mathrm{CO}_{2}$ and to promote exchange between the thorium, uranium in the tracer and the thorium, uranium in the sample.

Note 2. Carbonate free concentrated $\mathrm{NH}_{4} \mathrm{OH}$ is used to insure complete precipitation of uranium, since uranyl carbonate complexes are highly soluble. The mixture is digested, and is allowed to stand to help the floculation of the precipitates.

Note. 3. Reprecipitation removes calcium and magnesium from the precipitate.

Note 4. This column is prepared as follows. Dowex-1-x8 $\mathrm{Cl}^{-}$. form 200 400 mesh resin is washed once wi th distilled water. The water resin slurryis added to water filled column until the resin.fills the column to the desired length... The column: is then washed with $5 \mathrm{ml}$. $\mathrm{H}_{2} 0$ and $5 \mathrm{ml}$. $8 \mathrm{~N}$ HCl al ternately three times. Just before the sample is passed through the column, the column. is washed once more with $5 \mathrm{ml}$. of $8 \mathrm{~N} . \mathrm{HCl}$.

Note 5.: Sometimes peptization occurs when the precipitate is : washed with pure water. When this happens the mixture is brought to near boiling.: to coagulate the precipitates.

Note...6: .This column: is :prepared as follows. Dowex-1-x8 $\mathrm{Cl}^{-}$- form 200-400 mesh resin is washed once with distilled water. The water resin slurry is added to the water filled column unt the resin fills the column to the desired length. In order to free the resin from impurities, the column is cleaned by expanding: and contracting the resin bed by changing to various anion forms. The column is washed with $5 \mathrm{ml}$ of iN $\mathrm{HCl}$ and $5 \cdot \mathrm{ml}$. of $\mathrm{H}_{2} \mathrm{O}$-alternately three times. . I t is then converted to $\mathrm{NO}_{3}{ }^{-}$form by passing $20 \mathrm{ml}$. of $2 \mathrm{M} \mathrm{NaND}_{3}$ through it. The conversion to the nitrate form. is insured by testing the effluent for $C^{*}$ with $0.1 M$ 
$\mathrm{AgNO}_{3}$ solution. After it is converted to $\mathrm{NO}_{3}^{-}$form, the column is washed with $5 \mathrm{ml}$. of $\mathrm{H}_{2} \mathrm{O}$ and $5 \mathrm{ml}$. of $7 \mathrm{M} \mathrm{HNO}_{3}$ alternately three times. Just before the sample is passed through the column, the column is washed 'once more with $2 \mathrm{ml}$. of $7 \mathrm{M} \mathrm{HNO}_{3}$.

Note 7. The electrodeposition cell is shown in Figure 9. The Sargent-Slomin Electrolytic Analyzer is used:for electroplating. A clean coiled platinum electrode inserted into the stainless steel chuck on the motor bracket of the analyzer is used as a revolving anode. A platinum planchet or a stainless steel planchet forms a cathode and is held in place on the bottom of the glass cell by applying Carter's rubber cement between the contact surfaces. The distance between the electrodes is about 0.5 centimeters.

Note 8 . The platinum planchets and the stainless stell planchets are cleaned and degreased by treating with concentrated ritric acid and carbon tetrachloride. Platinum disks are heated to dull red before and after mounting the source in order to improve the resolution in the a) pha spectrum:

Note 9. Sometimes. a third:l iquid phase appears in the extraction of ferric chloride-by isopropyl-ether. When this happens, distilled water is added to the graduated test tube and the mixture is shaken over again. This is repeated until the system is back to a two-phase system. Possible explanations for the formation of the third phase are given by Nachtrieb et al.75 and Laurene et al 76

Note 10. It is possible that $\mathrm{Pa} 231$ is -present with the uranium isotopes on the planchet.. As : protactinium.is.strongl.y adsorbed on Dowex-1 anion exchange column from $8 \mathrm{~N}, \mathrm{HCl}$. it may be eluted from the column with 0:IN HCl and electrodeposited onto the stainlesis steel planchet, along 


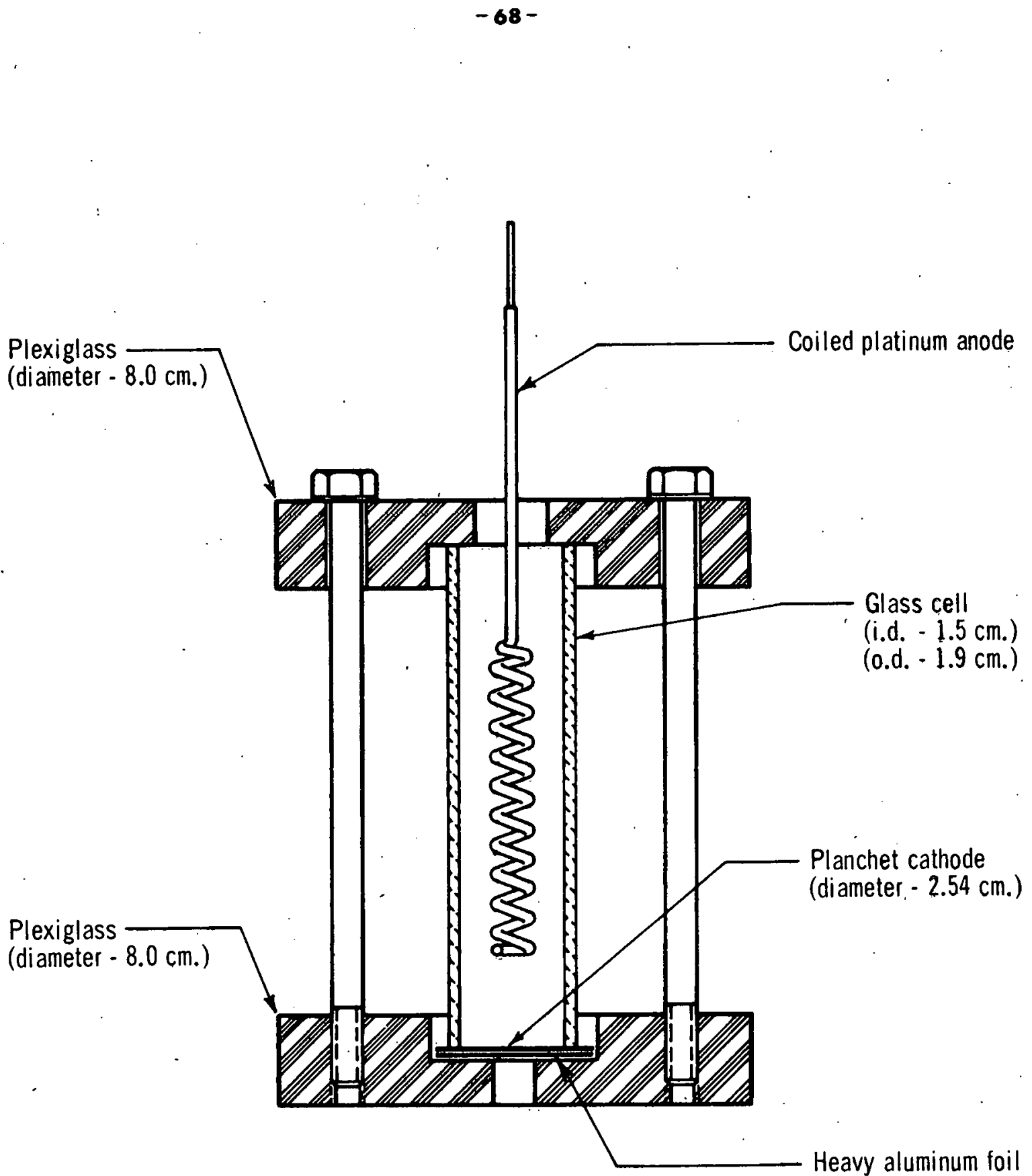

Heavy aluminum foil

Figure 9. Electrodeposition Cell 
with uranium. This is not certain for the tendency of protactinium to deposit on the walls of glass vessels is well-publicized. The exact amount of Pa 23.1 present is not known, however, one can estimate the maximum amount... which may be present.

$\mathrm{Pa}^{231}$, a 32480 year alpha emitter, is a decay product of $\mathrm{U}^{235}$. Fifteen percent of Pa 231 alpha particles have energies such that they appear.in the U234 peak region...

The deficiency of Fa 231 in ocean water leads one to expect that Pa231. in modern.marine molluscan shelis is nearly zero 77.78 the maximum activity of $\mathrm{Pa} 23$ ! in. fossit shells is determined by assuming that Pa 23 ! . is in secular equilibrium with $U^{235}$. The maximum activity of $\mathrm{Pa}^{231}$ which may appear in the energy range of $\mathrm{U}^{234}$ is calculated to be $0.7 \%$ of $\mathrm{U}^{234}$ activity by assuming the activity ratio of $U^{234}$ to $U^{238}$ to be 1.0 in fossil shells, and by using the value of 21.96 as the ratio of specific activities of $u^{238}$ to $U^{235}$. This is smaller than the uncertainty from counting. statistics." If $\mathrm{Pa} 231$ is present, $85 \%$ of its alphas should appear between the $U^{234}$ and $U^{232}$ pea.ks. No peak was observed in whis region so no correction for $\mathrm{Pa} 231$ was made...

\section{TOTAL -URANIUM ANALYSIS}

\section{A: Fluorimetric Method:}

The very low uranium content of naturally occuring calcium carbonates, 0.01 to $5 \mathrm{ppm}$, makes it necessary to use a sensitive method for the uranium determinations. Exposure of certain uranyl salts to ultraviolet light of wavelength $3400-3650 \AA$ results in fluorescence bands in

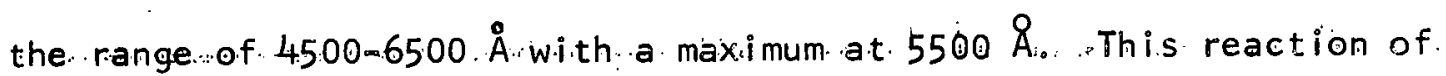
uranyl -ions; ; in the wavelength region stated, is specific for uranium 2, ,

77 W. M. Sackett, Science, 132,1761 (1960)

78 W. S. Moore and W. M. Sackett, J. Geophys. Res, 69, 5401 (1964) 
and permits the determination of uranium in amounts as low as $10^{-11} \mathrm{~g}$. The fivorescence output is a linear function of the uranium content of the sample. The fluorescence is markedly enhanced by fusion of the sample with sodium filuoride, li thium fluoride, or a mixture of alkali fluerides with alkali carbonates:

A number of elements and compounds are known to quench the uranium fluorescence with the degree of quenching action depending on their concentration. $\mathrm{Ag}, \mathrm{Au}, \mathrm{Ca}, \mathrm{Ce}, \mathrm{C} \odot, \mathrm{Cr}, \mathrm{Cu}, \mathrm{Fe}, \mathrm{HNO}_{3}, \mathrm{H}_{3} \mathrm{PO}_{4}, \mathrm{Ir}, \mathrm{Mg}, \mathrm{Mn}, \mathrm{Ni}$, $\mathrm{Pb}, \mathrm{Pt}, \mathrm{Pu} ; \mathrm{Si}$. Th and $\mathrm{Zn}$ are the materials possessing possible queriching action.

Two basic techniques can be used to minimize the effect of quenching agents. Where the uranium content of the sample is sufficiently high, dilution of the solution may overcome quenching difficulties. The other technique consists of spiking aliquots of the sample solution with various known amounts of standard uranium solution.

The following procedure is a modification of one described by Grimaldi and Levine. 79

A) Uranium Extraction Procedure

Step 1. Pipette an aliquot of sample solution equivalent to 2 to 3 grams of solid sample into a $30 \mathrm{ml}$. beaker. Heat and swirl beneath heat lamp until. a thick paste is obtained. Dissolve the paste in $0.35 \mathrm{ml}$. of concentrated $\mathrm{HNO}_{3}$ and wash quantitatively with distilled water into a. 50 $\mathrm{ml}$. graduated test tube. Make the volume to $5 \mathrm{ml}$. either by adding distilled water or by evaporațing beneath a heat lamp. (Note 1.)

Step 2. Add 7.0 grams of $\mathrm{Al}\left(\mathrm{NO}_{3}\right)_{3} \cdot 9 \mathrm{H}_{2} \mathrm{O}, \mathrm{A}$. R. grade to the $5 \mathrm{ml}$. of solution. Heat gently over a low flame until the aluminim nitrate

79 F. S. Grimaldi and H. Levine, Geol. Survey Bull, 1006, 43 (1954) 
is completely dissolved. Allow the solution to cool to room temperature.

Step. 3. Add $10 \mathrm{ml}$. of A. R. grade ethyl acetate to the solution, cap tightly with a polyethylene stopper, shake with a Vortex mixer for three minutes and centrifuge for about 30 seconds at $750 \mathrm{rpm}$. Transfer the ethyl acetate layer quantitatively through a funnel fitted with a dry No. 2 Whatman paper into a. $30 \mathrm{ml}$. beaker. (Note 2.)

Step 4: Repeat the ethyl acetate extraction twice using $10 \mathrm{ml}$. of ethyl acetate each time; and filtering through the same filter paper and into the same $30 \mathrm{ml}$. beaker. After the third extraction wash the filter paper.with $5 \mathrm{ml}$. of ethyl acetate and evaporate the combined extracts to dryness under a heat lamp. (Note 3.)

Step 5. Dissolve the residue. in $1 \mathrm{ml}$. of concentrated $\mathrm{HNO}_{3}$ transfer quantitatively to a $5 . \mathrm{ml}$. volumetric flask and make up to volume with $\sim$ distilled water.

\section{B) Spiking and 'Fusion Procedure}

Step 1. To three of six clean gold dishes add an appropriate al iquot of a standard uranium solution. This is normally $100 \lambda$ of a 1 microgram/ml. uranium solution. Evaporate to dryness beneath a heat lamp. (Note. 4.)

Step 2. To all sixidishes add an appropriate al iquot of the sample solution (normally, $0.1 . \mathrm{ml}$. for samples containing 0.1 to $1.0 \mathrm{ppm}$. uranium) and take to dryness beneath. a. heat lamp.... (Note 5..) ...

Step 3. Add $300 \pm 2 \mathrm{mg}$. of flux to each dish, al so, to a seventh clean dish to be employed as a blank. Fuse between 625 and 650 degrees centigrade for 15 minutes in a muffle furnace. Remove and allow to cool in a dessicatör for 20 minutes. Read the fluorescence of each dish. (Note 6.) 


\section{C) Calculation of Uranium Content}

As the fluorescence intensity is directly proportional to the amount of uranium present; a direct proportion can be set up which will give the uranium content of the final sample aliquot. Letting $A$ equal. the fluorescence reading; corpected for blank, of the sample aliquot, and A she fluoresence reading, corrected for blank; of the spiked sample aliquot, the micrograms of uranium in the final sample aliquot may be calculated:

$\frac{\dot{A}}{A_{S}-A}=\frac{\text { micrograms of uranium in final sample al iquot }}{\text { micrograms of uranium added in spike }}$
Since the total as imple volume is $5 \mathrm{ml}_{\ldots-2}$ and the we ight of the sample is known, the above =value can reasily be converted to ppm. of uranium in the sample.

D.) Notes:

Note 1. The ameunt of $\mathrm{HNO}_{3}$ used gives a final concentration of about $7 \% \mathrm{HNO}_{3}$, by volume ... At this $\mathrm{HNO}_{3}$.concentration no appreciable change in ethyl acetate volume i.s observed during the extraction.

Note 2.0 The ethyl acetate is equilibrated with $7 \% \mathrm{HNO}_{3}$, to reduce the amount $r$ of aqueous phase dissolving into the organic phase, one

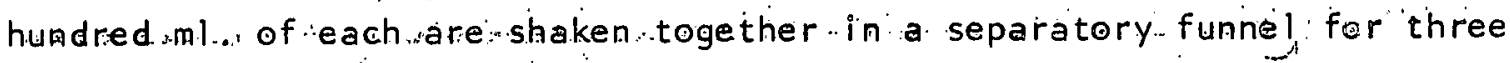
minutes and the aqueous phase irs drained off.

A polyethylene. stopper is used to cap the test tube since ethyl acetate dissolves rubber produci ig a. gummy residue.

In the event alumilinum nitrate separates out of solution, redissolve .......t, by warming before commencing.., the next extraction.

Nate 3. .l.t will lube necessary to evaporate part of the solution before the final extraction to allow sufficient volume in the $30 \mathrm{mil}$ : beaker. 
Note 4.- A: preliminary of one aliquot of sample solution is. made-todetermine the approximate uranium content. The aliquot of sample solution or the urani um standard-solution mis adjusted so the fluorescence of both can be read between 10 and 90 on the same sensitivity setting.

Note 5. The städard turanium solution is prepared-by weighing

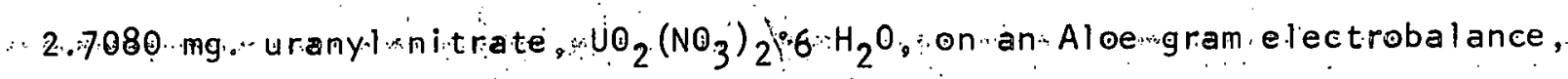
dissolvimg in $7 \% \mathrm{HNO}_{3}$ and making up the volume to 1 witer with $7 \% \mathrm{HNO}_{3}$. $\therefore$ The solution contains -284 m i.crogram uran i.um/-ml

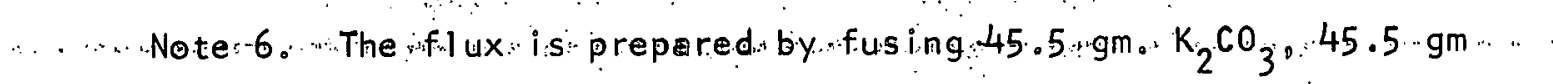
$\mathrm{Na}_{2} \mathrm{CO}_{3}$ and 9 gm. $\mathrm{NaF}$ in a large platinum dish and grinding the cooled flux to a f.i ne powder.

... If the fluorimetric readings for the triplicates are erratic, refuse for an additional ' 5 minutes s...However, avo i d exceeding. 650 degrees ...centrigrade as this willil. resul t. in a sharp decrease in filuorescence. This may happen for only one or two dishes in the hot part. of the furnace producinger ratic result.ts. The instrument used is a Jarrell. Ash JA-2600. Gal vanek Morrison. Fluorimeter.

The gold dishes, approximately $15 \mathrm{~mm}$. in diameter and $4 \mathrm{~mm}$. deep; are pressed from a. $20 \mathrm{mil}$. gold sheet.

\section{B. Alpha Pulse Height Analysis Method}

The total uanium content of a sample can be obtained from'the result of alpha pulse height analysis on the uranium isotopes isolated from the sample which is spiked with $\mathrm{U}^{232}$.

The method is described on page 49 to 64 of this thesis. A comparison of some of the uranium results obtained by the fluorimetric method and the alpha pulse height analysis method is shown in Table 16. 
Table 16 .

Comparison of Uranium. Results

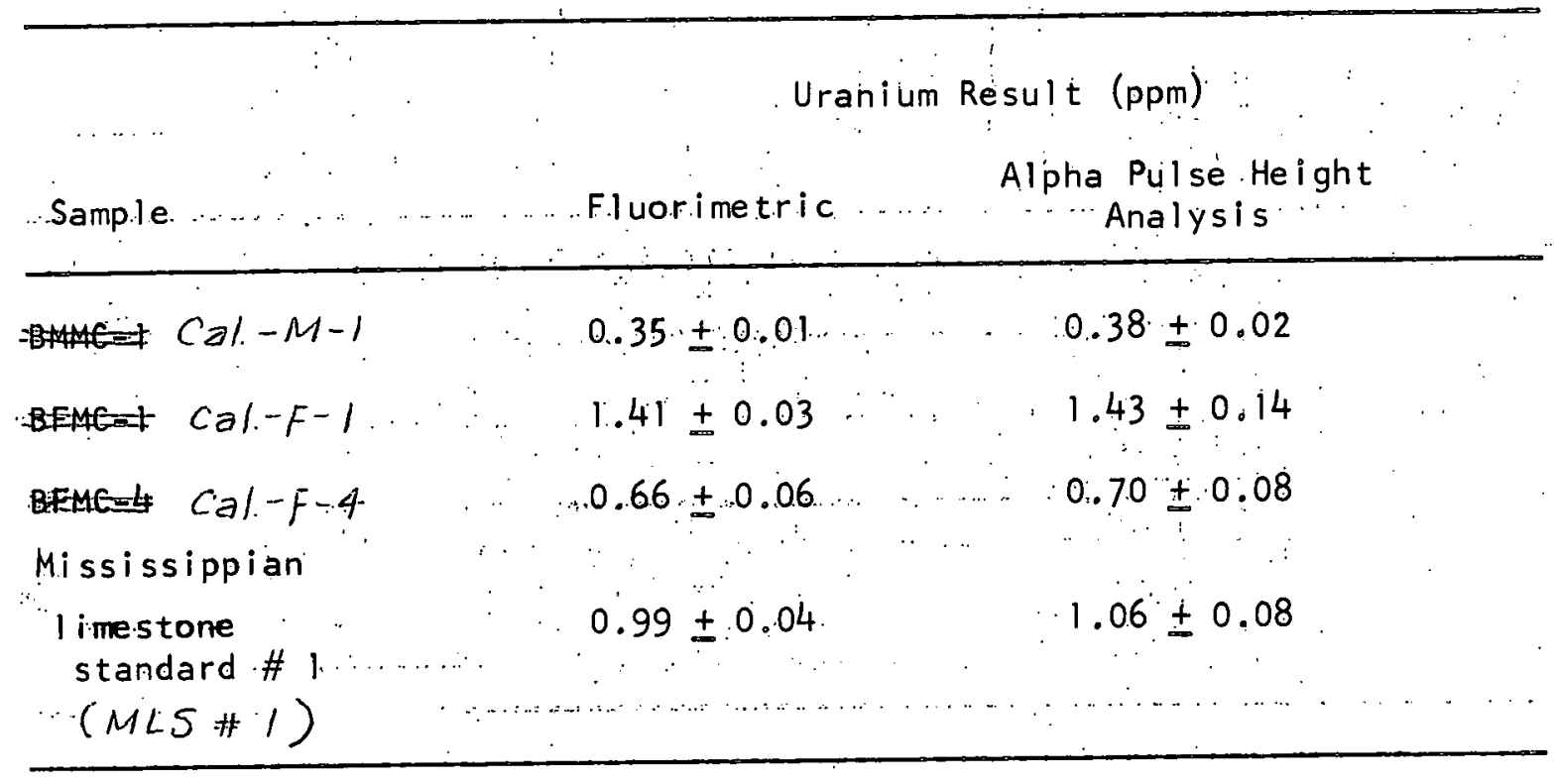


APPENDIX III DETERMINATION OF CALCIUM CARBONATE MINERALOGY -BY X-RAY DIFFRACTION*

The aragonite-calcite ratios in the calcium carbonate shells are determined by the method described by Davies and Hooper. 80 All samples are ground to pass a 170 mesh sieve and are caught on a. 270 mesh sieve. The radiation from a copper target ( $C_{u} K_{\alpha}$ radiation). is used with a Picker diffractometer. A nickel filter is inserted in front of the GeigerMueller tube to absorb the $k_{\beta}$ radiations emitted from the copper target as their reflection interfered with the principal aragonite reflection. The 4 ines used for the analysis are the: 1074 calcite line and the 111 and 021 aragonite lines combined. (Figure $10 \%$.

The calibration curve is constructed by mixing pure calcite and pure aragonite in different proportions, measuring the $I_{c} /\left(1_{c}+l_{a}\right)$ iratio and plotting these values against weight percent calcite: (Figure 11 ). Having constructed the calibration curve, the percent aragonite in the sample can be determined from the curve.

The lowest level of calcite detection is greater than $3 \%$ for randomly oriented samples. When compressed slightly, calcite orients on its clevage face and can be easily detected at $3 \%$ but is not detectable at $1 \%$. Table 17 shows the results obtained.

:Mineralogical analyses were made by M. W. Reams, Department of Earth Sclences, Washington University. (1963)

${ }^{80}$ T. T. Davies; and P. R. Hooper, Mineralogical Magazine, 33, 608 


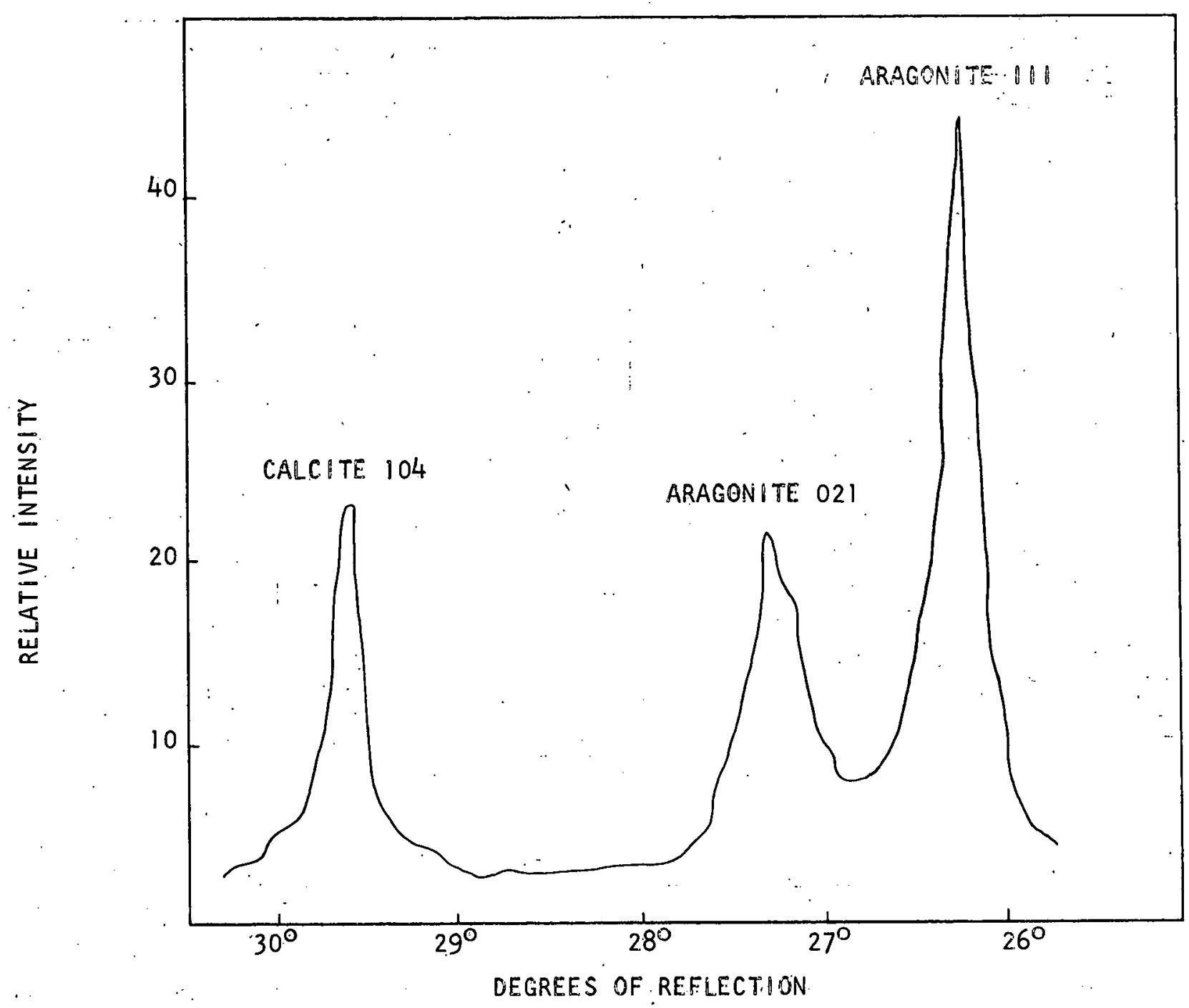

Figure 10. The X-Ray Spectrum of $90 \%$ Aragonite, Pure STROMBUS GlGAS, mixed with 10\% Pure.Calcite. (A'fter Davies and Hooper). 


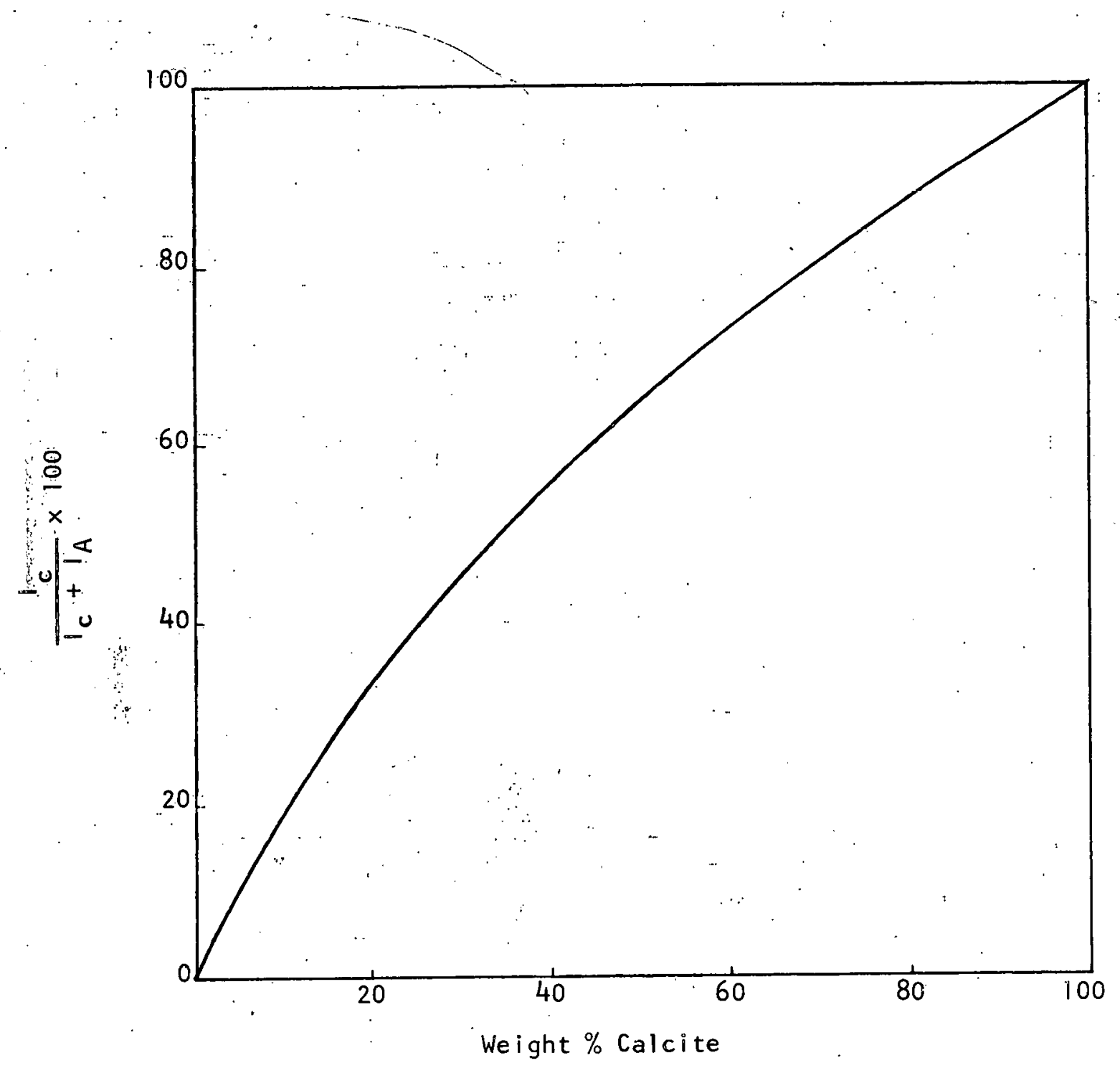

Figure 11. Calcite: Aragonite Calibration Curve. (After Davies and Hooper). 
Table 17

Mineralogy of the Molluscan Shell Samples

...Sample Des.ignat.ion... General. Location

Percent Calcite

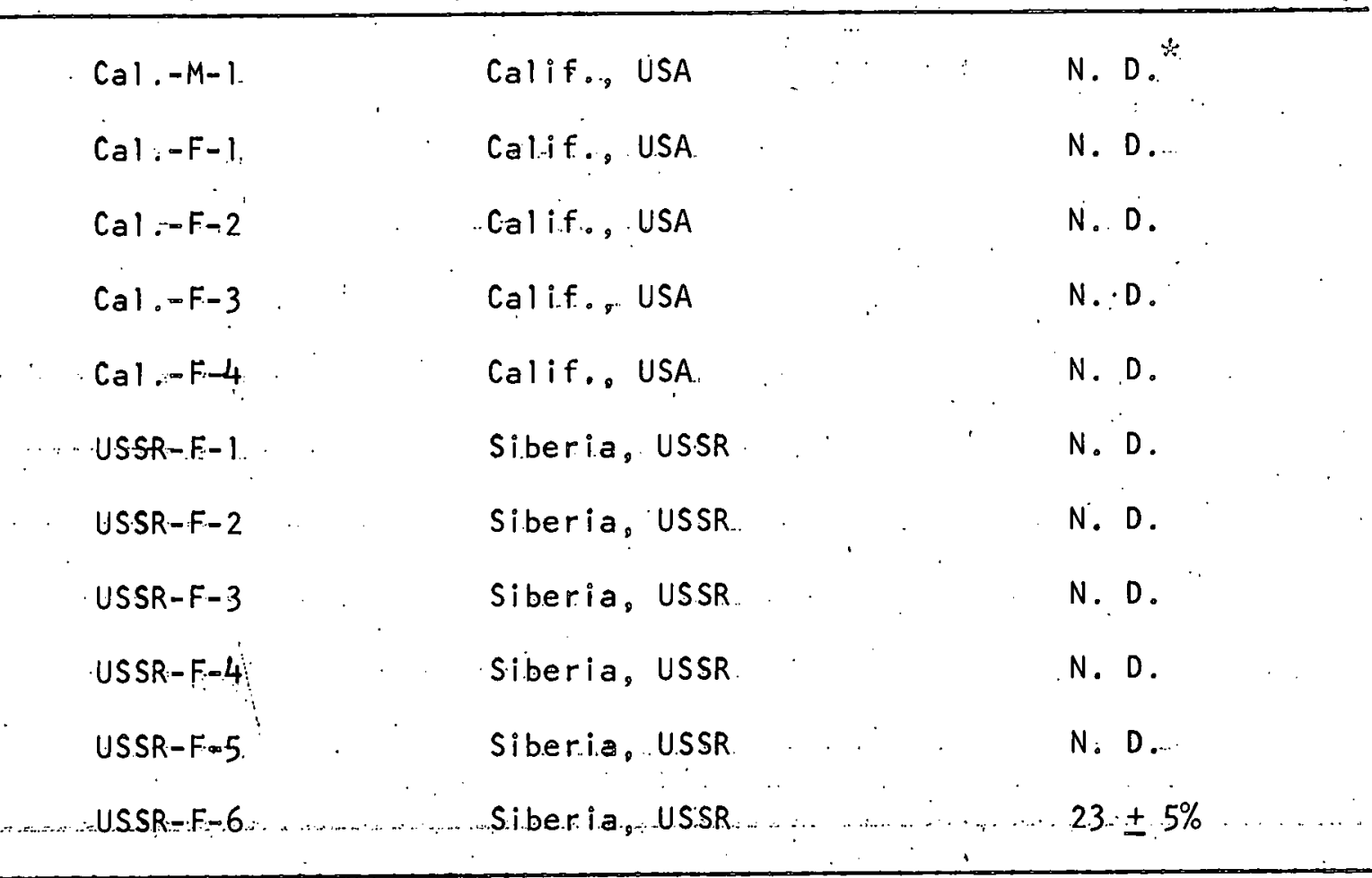

$\because$ N. D. = not de tectable. (less than 1-2\%)

USSR-E-6 is the only sample containing a rel lably de tectable amount of calcite.. It was noticed that one of the generain this sample, Nuculana, had been preserved with its valves unseparated o: This allowed mud to fill the cavilty.... Separate diffafraction. patterns of the Nuculana fraction and - the other genera indicated that calci.te was almostexclusively in the Nuculana fraction of the sample. Whe the r the mud filling the cavities of Nuculana was originally aragonite or calcite or a mixture of the two was inot determined. 
1. Samples received from W. C. Bradley* (collected by W. 0. Addicott)--- United States Geological Survey

Sample designation

Cal $-M-1$

Cal : $-M-3$

Cal. $-F-1$

Cal . F-2

C'al. $.-F-3$

Cal o $-\mathrm{F}-4$
Description*

Modern Protothaca staminea, a sand-dweller, was collected at Point Año Nuevo, Califơrnia.

Modern Schizothaerus nuttalli a sand-dweller; was collected from the intertidal zone at Point: Año Nuevo, Cal ifornia

Pleistocene Protothaca staminea, a sand-idweller,"was collected from the basal:marine deposits on the first - marine terrace at Santa Cruz, Cal if.; along West Cliff Drive. The deposits are about 15 ' thick at the collecting location.

Pleistocene Panitella penita, a rock borter" "was collected from holes in the bed rock platform of the first terraceion the north side of Point Año Nuevo, California

(P)

Pleistocene Schizothaerus nuttalli. a sand-dweller, was collected from the basal, marine deposits on the first màine terrace at Santa Cruz, Calif., along West Cliff Drive. The deposit's are 'about $15^{\circ}$ thick at the collecting location.

$" \therefore$ :

Pléistocene Macoma inquinata, a sandswe l ler: was collected from the basal marire deposits of the first marihe terrace along the south side of Año Nuevo Point, 20 miles north of SantaCruz, California.

*W. C. Bradley, personal communication (1965) 
2. Samples Received from D. M. Hopkins* (collected by D. S. McCulluch) -. United States Geological Survey

Sample Designation

Greenl:d. -F.-62 AMh 24

Alas. $-F-D-1116$

\section{Description}

The shells: were collected in 1962 from Northeast shore of Baldwin Penninsula, Gréenland $\left(66^{\circ} 34^{\circ} 02^{\prime \prime}\right.$.N. lat. and $161056.25 . " W_{0}$ long)

One hundred grams of firm, apparently well-preserved shel is were picked out for analysis:

The shelly were collected from the intermediate Beach near Nome, Alaska and consisted of a mixture of small and large sea shells, all showing evidence of weathering. The deposit from which these shells were collected is presumed to have been laid down during "the Aftonian interglacial interval $(1,300,000$ yrs. B.P $)$... The sedimehts beneath the coastal plain at' Nome are generally perennially: frozen'to bedrock, but in some places a. layer of sediment resting immediately upon bedrock is thawed and contains circulating ground water. Evidence in the region indicates that the perennially frozen ground probably thawed out completely during the last (Sangamoh) interglacial cycle. Thus, specimen Alas:-F-D-1116 probably has been subjected to thawing temperatures for at least a. few tens of thousands of years of its history and will have been in contact with circulating ground water during that interval. 
3. Samples-rece-ived-from T.-Karilstrom. (collected by V. A. Zubakov) -.. United States Geological Survey.

Identifications of the Pelecypods are by H. L. Levin, Washington University, Department of-Earth Sciences

- Sample-designation

USSR-F- 1

USSR-F-2

USSR-F-3

USSR-F-4

USSR-F-5

USSR-F-6

\section{Description}

Astarte and Yoldia

The Anzhu II Transgression, New

Siberia. Island, plus $20-40 \mathrm{~m}$.

Geol. Age; $1113^{a}$ (Approx. 22-45,000

yrs. B. $\left.P_{0}\right)$

Astárte

The Kaŕginian Transgression N. Enisey

District, $69^{\circ} 5^{\circ} \cdot \mathrm{N}$. Lat., plus 22-30 m.

Geol: Age: $11 I_{3} \mathrm{Krg}$ (Approx. 22-45,000

yrs: $\left.B_{i} \cdot P_{i}^{\prime}\right)$

\section{Astarte}

The Kazantsevian Transgression, N . Enisey District, Kazant, $70^{\circ} \mathrm{N}$. Lat., plus $60-80 \mathrm{~m}$.

Geol. Age: Ill, Kz (70-100,000 yrs:

B. P.)

Amiantist

The Kazantsevian Transgression,. R. Agàpa, N. Enisey. District, $70^{\circ}, N$. Lat., plus $60-80^{\circ} \mathrm{m}$.

Geol. Age: I Il, Kz (70-100,000 yrs. B. $\left.P_{0}\right)$

Entodesma*, Macoma*", and Yoldia

The Sanchugovian 'Transgression, R.. Bol. Kheta, N. Enisey District, $69^{\circ}$.N. Lat., plus $100-150 \mathrm{~m}$.

Geol. Age: : 1/4s $(110,000-150,000$ yrs. B. $\left.P_{0}\right)$

\section{Nuculana}

The Sanchugovian Transgression, River.'Enisey $65^{\circ} \mathrm{N}$. Lat.

Geol. Age $\because, 11_{4}$ s equals Eniseyian

horizon (1/4 e) (140-180;000 yrs. B.P.)

*The generic name of the-shell is questioned because of the poor preservation which makes the identification difficult. 
4. Mississippian limestone standard received from R. B. Martin -Mississippi Lime Company, St. Genevieve, Missouri (Mississippian Limestone standard \# 1)

The limestone is representative of the oolitic portion of the Spergen formation of the Mississippian age. The supplier furnished the following analytical data:

$$
\begin{aligned}
& \mathrm{CaCO}_{3} \\
& \mathrm{MgCO}_{3} \ldots \\
& \mathrm{SiO}_{2} \\
& \mathrm{Al}_{2} \mathrm{O}_{3} \\
& \mathrm{Fe}_{2} \mathrm{O}_{3} \\
& \text { Others }
\end{aligned}
$$

The sample was placed in a parge polyethylene bag and agitated manually for about ten minutes. Portions of the sample were then removed and. sent to a number of laboratories for uranium analysis. The results which were reported are tabulated below:

Me thod

Fluorimetric

Fluorimetric

Fluorimetric

Flourimetric

Colorimetric

I sotope

Dilution

Neutron

Activation

Alpha Spectrometry
Analyst

Alice Caemmerer U.S.G.S.

Edward J. Fennelly U.S.G.S.

William M. Sackett Washington University

Mary M.. H. Cheng Washington University.

Mitsunobu Tatsumoto Scripps Institution of Oceanography

James Cobb Lamont Geological observatory

William M. Sackett Wäshington University Mary M. $H_{\text {. Cheng }}$ Cheng
Washington University
Report (ppm U)

1.1 .1 .2

0.8

$1.02(+0.05)$

$0.99(+0.04)$

$1.09( \pm 0.05)$

$1.04(+0.06)$

$1.07(0.05)$

$1.06( \pm 0.08)$ 
Table 18

Uranium, Thorium and Radium Content of Mississippian Limestone Standard \#1

\begin{tabular}{|c|c|c|c|c|c|c|c|c|c|}
\hline $\begin{array}{l}A_{U} 238 \\
(d / m / g)\end{array}$ & $\begin{array}{l}A_{T h} 230 \\
(d / m / g)\end{array}$ & $\begin{array}{c}A_{\mathrm{Ra}} 226 \\
(\mathrm{~d} / \mathrm{m} / \mathrm{g})\end{array}$ & $\begin{array}{l}A_{T h^{232}} \\
(d / m / g)\end{array}$ & $\begin{array}{l}A_{T h} 228 \\
(d / m / g)\end{array}$ & $\begin{array}{r}A_{T h} 227 \\
(d / m / g)\end{array}$ & $\frac{A_{T h} 230}{A_{U^{2}} 238}$ & $\frac{A_{R_{a}}{ }^{226}}{A_{U^{238}}}$ & $\frac{A_{U^{2}} 23}{A_{U^{2}} 238}$ & $\begin{array}{l}\text { Analyst } \\
\text { (Date) }\end{array}$ \\
\hline $\begin{array}{c}0.75 \\
(+0.04)\end{array}$ & $\begin{array}{c}0.72 \\
( \pm 0.07)\end{array}$ & - & $\begin{array}{r}0.035 \% \\
( \pm 0.003)\end{array}$ & $\begin{array}{c}0.03 \\
(+0.01)\end{array}$ & - & $\begin{array}{c}0.96 \\
(+0.10)\end{array}$ & - & - & $\begin{array}{l}\text { Sackett } \\
(1958)\end{array}$ \\
\hline - & $\begin{array}{c}0.79 \\
(+0.08)\end{array}$ & $\begin{array}{c}0.76 \\
(+0.04)\end{array}$ & $\begin{array}{r}0.035 \% \\
( \pm 0.003)\end{array}$ & $\begin{array}{c}0.06 \\
( \pm 0.02)\end{array}$ & $\begin{array}{c}0.01 \\
+0.03)\end{array}$ & $\begin{array}{c}1.04 \\
(+0.10)\end{array}$ & $\begin{array}{l}1.01 \times 1 \times 1 \\
( \pm 0.08)\end{array}$ & $\begin{array}{c}1.01 \\
(+0.02)\end{array}$ & $\begin{array}{c}\text { Blanchard } \\
(1963 \\
1965)\end{array}$ \\
\hline- & $\begin{array}{r}0.78 \\
(+0.08)\end{array}$ & $\begin{array}{c}0.76 \\
(+0.04)\end{array}$ & $\begin{array}{r}0.035 * \\
( \pm 0.003)\end{array}$ & $\begin{array}{c}0.04 \\
( \pm 0.02)\end{array}$ & $\begin{array}{c}0.04 \\
(+0.04)\end{array}$ & $\begin{array}{c}1.03 \\
(+0.10)\end{array}$ & 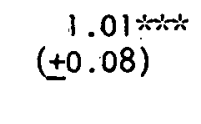 & $\begin{array}{c}0.99 \\
(+0.02)\end{array}$ & $\begin{array}{c}\text { Blanchard } \\
(1963, \\
1965)\end{array}$ \\
\hline $\begin{array}{c}0.76 \\
(+0.03)\end{array}$ & - & $\begin{array}{r}0.78 \\
(+0.04)\end{array}$ & - & - & - & - & $\begin{array}{c}1.03 \\
+0.07)\end{array}$ & - & $\begin{array}{c}\text { Broecker } \\
(1963)\end{array}$ \\
\hline $\begin{array}{c}0.73 \\
(+0.04)\end{array}$ & $\begin{array}{c}0.76 \\
+0.05)\end{array}$ & - & $\begin{array}{l}0.030 * x \\
(+0.006)\end{array}$ & $\begin{array}{c}0.032 \\
( \pm 0.006)\end{array}$ & - & $\begin{array}{c}1.04 \\
+0.09)\end{array}$ & - & $\begin{array}{r}1.02 \\
( \pm 0.05)\end{array}$ & $\begin{array}{l}\text { Cheng } \\
(1966)\end{array}$ \\
\hline- & - & - & - & - & - & - & - & $\begin{array}{r}1.01 \\
(+0.01)\end{array}$ & $\begin{array}{r}\text { Thurber } \\
(1962)\end{array}$ \\
\hline
\end{tabular}

* Th ${ }^{232}$ determined by neutron activation - by H. A. Potratz.

*t: Th ${ }^{232}$ determined by alpha spectrometry - by M. H. Cheng.

wh: Calculated by using Blanchard's radium value and Sackett's uranium value. 
Attree, R. W., Cabell, M. J., Cushing, R. L. and Pieron, J. J., Calorimetric Determination of the Half-Life of Thorium-230 and a consequent Revision to Its Neutron Capture Cross Section, Canadian J. Physics, 40, $194(1962)$

Barnes, J. W." Lang, E. J: and Potratz, H. A., Ratio of Ionium to Uranium in Coral Limestone, Science, 124, 175 (1956)

Bateman, H.., Solution of a System of Differential Equations Occurring in the Theory of Radio-active Transformations, Proc. Cambridge Phi 1. Soc., 15.423 (1910)

Blanchard, R. L., Uranium. Decay Series Disequilibrium in Age Determination of Marine Calcium Carbonates, PhD Thesis, Washington University, St. Louis; Missouri (1963).

Blanchard, R. L., U234/U238 Ratios in Coastal Marine Waters and Calcium Carbonates, J. Geophys: Res:, 20, 4055 (1965).

Bradley, W. C., Carbon-14 Date for a Marine Terrace at Santa Cruz, California, Bull. Geol. Soc. Amer., 67, 675 (1956).

Bragg, W. L., Atomic Structure of Minerals, Cornelli University Press, I thaca, p. $114(1937)$.

Broecker, W. S., A Preliminary Evaluation of Uranium Series Inequilibrium as a Tool for Absolute Age Measurement on Marine Carbenates, J. Geophys. Res., 68, 2817. (1963).

Broecker, W. S, and Thurber, D. L. Thurber, Uranium-Series Dating of Corals and Oolites from Bahaman and Florida Key Limestones, Science, 149, 58 (1965).

Buchanan, R. F. and Faris, J. P., Adsorption of the Elements from Nitric Acid by Anion Exchange, Proc. Int. Atomic Energy Agency, Copenhave. September (1960); or Radioisotopes in the Physical Sciences and Industry, Vol. I1, 361, (1962).

Cherdyntsev, V. V.., Chalov, P. I. and Khaidarov, G. Z., Tr. III sessi i komissi $i$ po. opredeleniyu absolyutnogo voziasta, lzu. Akad. Nauk SSSR, 175 (1955).

Cherdyntsev, V. V., Abundance of Chemical Elements. University of Chicago Press, Chicago, P. $107(1961)$.

Cherdyntsev, V. V., Orlov, D. P., Isabaev, E. A... and Ivanov, V. I., Uranium I sotopes in Nature. II. I sotopic Composition of Uranium Minerals, Geochemistry (English Translation)., No. 10, 927 (1961). 
Cloud, P. E., Behavior of Calcium Carbonate in Sea Water, Geochim. et Cosmochim. Acta, 26, 867 (1962)

Daniels, F., Kinetics and Thermoluminescence in Geochemistry, Geochim. e.t Cosmochim. Acta, 22 65 (1961).

Davies, T. T. and Hooper, P. R., The Determination of the Calcite: Aragonlte Ratio in Mollusc Shells by X-Ray Diffraction, Mineralogical Magazine, 33, 608: (1963)

Fanale, F. P. and Schaeffer; 0 . A., He-U Ratios for Pleistócene and Tertiary. Fossi 1 Aragon. tes, ...Science, 149 , 31.2 (1965) ..

Goldbérg, E, D. and Kolde., M.. Ionium-Thorfum in Deep Sea sediments of the Pacific., Science, 128, 175 (1958).

Grimaldi, F.. S. and Levine, H., The Visual Fluorimetric Determination of Uranium in Low Grade Ores, Geol. Survey Bull., 1006, 43 (1954).

Holland, H. D. and Kulp, J. L., The Transport and Deposition of Uranium. lonium and Radium in the Rivers, Oceans and Ocean Sediments, Geochim. et Cosmochim. Acta, 5, 197 (1954).

Kirby, H. W., Decay and Growth Tables for the Naturally Oceurring Radioactive Series, Anal. Chem., 26, 1063 (1954).

Koczy, F. F., Picciotto, E., Poulaert, G. and Wilgäin, S: Mesure des I sotopes du Thorium dans. L'eau de Mer, Geochim. ét Cosmochim. Acta, 11. 103 (1957).

Koide, M. and Goldberg, E, - U ranium-234/Uranium-238 Ratios in Séa Water, Progress in Oceanograghy, Pergamon Press, Vol .. 3, p. 173 (1965).

Kraus ...... A and Nelson, F., Anion Exchange Studies of the Fission Products, Proc. Fir rst. Int. Conf. on the Peaceful Uses of Atomic Energy, Geneva, $=-7, \cdot 1: 3 \div(1955)$.

$\mathrm{Ku}, \mathrm{T}$. L., An Evaluation of the U234/U238. Methods as a Toal for Dating Pelagic Sediments, J. Geophys. Re., 20, 3457 (1965).

Kulp, J. L., Turekian, K. and Boyd, D.. N. . Stron ium Content of Limestone and Fossils, Bull. Geol. Soc. Amer; 63, 701 (1952).

Latimer; W. M., The Oxidation States of the Elements and Theif Potentials in Aqueous Solutions; Prentice-Hall., Inc., P. 320 (1959).

Laurene, A...H., Campbel1, D.. E.., Wiberley, S: E, and Clark,.. H. M., .... The Extraction of Ferric Chloride by Isopropyl-Ether. :Part 1. The Significance of Water in the Extracted Iron Complex, J. Phys. Chem., 60, 901 (1956).

Lowenstam, H. A., Environmental Relations of Modification Composition of Certain Carbonate Secreting Marine Invertebrates, Proc. Nat. Acad. $\mathrm{Sci}, 40,39(1954)$. 
Moore, W..S. and Sackett, W. M. Uranium and Thorium Series Inequilibrium in Sea Water, J. Geophys. Res, 69, 5401 (1964).

Nachtrieb, N. H., Fryxell, R. E., The Extraction of Ferric Chloride by I sopropyl Ether. I11, J. Amer. Chem. Soc., 24, 897 (1952):

Nakanishi, M., Fluorometric Microdetermination of Ujanium. $V_{0}$ The Uranium Content of Sea Water, Bull. Chem. Soc. Japan, 24, 36 $(1951)$ :

Osmond, J: K. Carpenter, J. R. and Windom, H. L.., Th230/J234 Age of the ple ístocene Corals and Oolites of Florida, J. Geophys. Res., 70, 1843 (1965).

Rankama, K. and Sahama, T. G., Geochemistry. University of Chicago Press, Chicago, p: $287(1950)$.

Rosholt, J. Na, Shields, W. R., and Garner; E. L. I sotopic Fractionation. of Uranium in Sandstone, Science, 139, 224 (1963).

Sackett, W. M., Ionium-Uranium Ratios in Marine Deposited Calcium Carbonates and Related Materials, PhD Thesis, Washington. University, St. Louis, Missouri (1958).

Sackett, W: M., The Protactinium-231 Content of Ocean Water and Sediments, Science, 132, 1761 (1960).

Stearns, C. E.. and Thurber, D. L., Th230.. U234 Dates of Late Pleistocene Marine Fossils from the Mediterranean and Moroccan Littorals, Quaternaria, VII, Roma, 29 (1965).

Strominger, D., Hollander, J. M. , and Seaborg, G. T., Table of I sotopes, Rev. of Mod: Phys., 30, 788 (1958).

Tatsumoto, M: and Goldberg, E: D., Some Aspects of the Marine Geochemistry of Uranium, Geochim. et Cosmochim. Acta, 1.7, 201 (1959).

Thompson, T. G. and Chow; T. J., Papers in Marine Biology and Oceanography, Suppl. to Vol. 3 of Deep. Sea Research, 20 (1955).

Thurber, D. L., Anomalous $\mathrm{U}^{234} / \mathrm{U}^{238}$ in Nature, J. Geophys. Res., 67. $4518 .(1962)$.

Thurber, D. L., Broecker, W. S., Blanchard, R. L. and Potratz; H. A., Uranium-Series Ages of Pacific Atoll Coral, Science, 149.55 (1965).

Thurber, D. L., The Dating of Molluscs from Raised Marine Terraces by the Thorium-230/Uranium-234 Method,: Symposium on Marine Geochemistry, Narragansett Marine Laboratory, University of Rhode Island, Occasional Publication No. 3, I (1965).

Wray, J. L. and Daniels, F., Precipitation of Calcite and Aragonite, J. Amer. Chem. Soc., 79, 2031 (1957).

Zeller, E. J: and Wray, J. L., Factors Influencing Precipitation of Calcium Cạrbonate, Bull. Amer. Ass. Petrol. Geol., 40, 140 (1956). 